S
636.313 Peters, Donald J Inventory of

F2ifbr fishery resources

1990

in the Blackfoot

River and major

tributaries

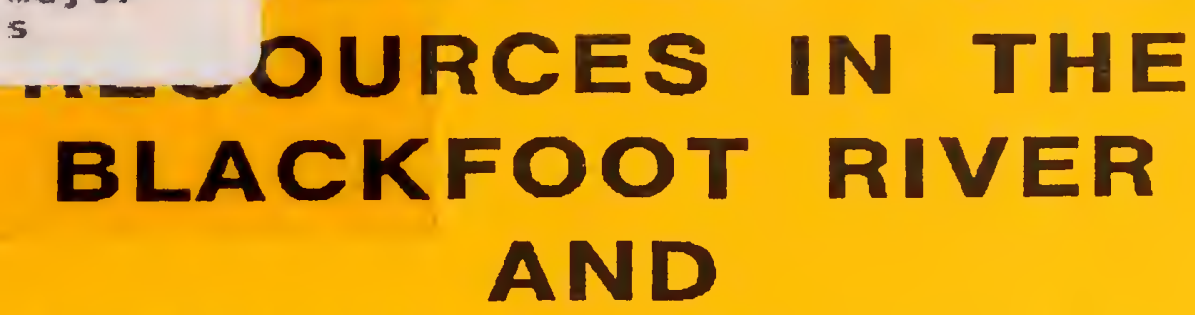

LEASE RET

MAJOR

TRIBUTARIES

SIATE COUUMENTS COLLECTION

OCT : 1991

MONTANA STATE LIRRARY

1515 E. 6th AVE.

HELENA, MONTANA 59620

MONTANA STATE LIRARY
1515 E. 6th AVE.
HELENA, MONTANA 59620

isting

(6)

(1)

(10)

籍

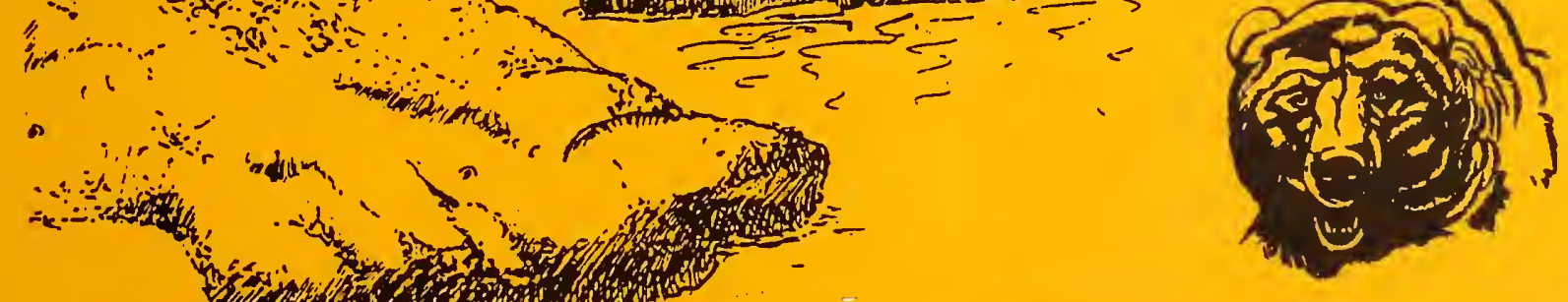

is

Montana Department

of

Fish, Wildlife \& Paries 
JAN $9-1992$

log 26.1992

SEP $\quad 91992$

MAR 241093

2ix. $+101 / 3$

ECT 17200$\}$

\section{MAY 282003}




\title{
INVENTORY OF FISHERY RESOURCES \\ IN THE BLACKFOOT RIVER \\ AND MAJOR TRIBUTARIES
}

\author{
BY \\ MONTANA DEPARTMENT \\ OF \\ FISH, WILDIIFE AND PARRS
}

PRINCIPLE INVESTIGATOR

DON PETERS

AUGUST, 1990 
ABSTRACT

In 1989 major tributary streams in the Blackfoot River drainage were surveyed for fish population composition and general fish habitat conditions. Fish populations in the Blackfoot River were monitored in established sampling sections at Johnsrud Park and scotty Brown Bridge. A new monitoring section was established on the North Fork of the Blackfoot River. Collections of fish liver tissue were made in the headwaters to determine toxic metals concentrations. The status of species of special concern, bull trout and westslope cutthroat, were evaluated and a recovery management plan developed. Fish habitat problems were identified in the tributary streams.

Nineteen major tributary streams in the Big Blackfoot River were surveyed in 1989. Fish populations of catchable-sized cutthroat, the dominate species in most of the streams, are considered poor for western Montana. Low densities of adult cutthroat and young-of-the-year (YOY) may indicate recruitment sensitive populations. Lower segments of most tributaries carried populations of brown and rainbow trout, particularily younger age classes. The lack of physical barriors to upstream migration for the rainbow and brown trout suggest environmental limitations for these species in middle and upper stream reaches.

significant declines were observed for older aged rainbow trout in the Johnsrud section. Estimated densities declined in 1989 to 12.5 per 1,000 lineal ft of stream from 45 in 1985 . The Scotty Brown Bridge section first sampled in the fall of 1988 showed to significant change in population in the June, 1989. The population of all trout larger than 4 in. TL was 61.4 per 1,000 ft. Species of special concern, westslope cutthroat and sometimes bull trout dominated fish samples in the headwater reaches of most tributaries. Only 3 out of the 19 sampled tributary streams had significant numbers of YOY bull trout.

Lethal concentration of cadmium were found in the livers of cutthroat trout in sections of the Blackfoot River below the Mike Horse Mine tailings pond ( $8.8 \mathrm{ug} / \mathrm{g} \mathrm{dry}$ weight). Low densities of YOY and resulting older aged cutthroat may be attributable to the high metals concentrations in the upper river system sediments since the failure of a tailings pond in 1975. 


\section{ACRNOWLEDGEMENTS}

I would like to thank the officers and club members of the Big Blackfoot Chapter of Trout Unlimited that strongly supported the Department for continued funding of this project and their continuing involvement in the Big Blackfoot River.

A special thanks to Pat Graham, Jerry Wells and Dennis Workman for their involvement in getting this project initiated and fully funded.

Thanks are extended to the field crew Ron Pierce and Eric Priest for the extra long hours and dedication to details with the field work and data analysis. 
PAGE

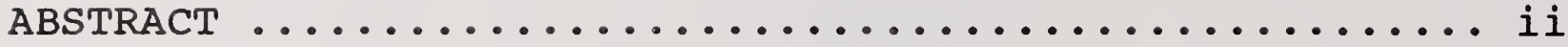

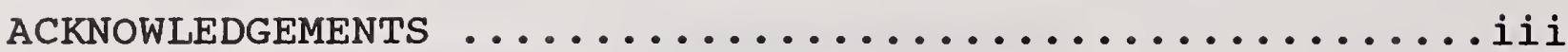

TABLE OF CONTENTS........................ iv

INTRODUCTION AND OBJECTIVES.................... 1

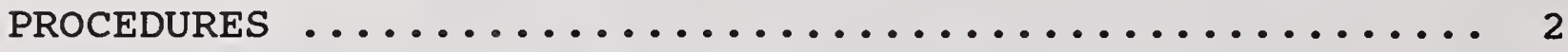

RESULTS $\ldots \ldots \ldots \ldots \ldots \ldots \ldots \ldots \ldots \ldots \ldots \ldots \ldots \ldots \ldots \ldots \ldots$

Blackfoot River fish populations .............. 4

Headwaters toxic metals problem ............... 7

Native fish species evaluations ............... 8

Tributary stream evaluations .................. 9

DISCUSSION $\ldots \ldots \ldots \ldots \ldots \ldots \ldots \ldots \ldots \ldots \ldots \ldots \ldots \ldots \ldots \ldots \ldots \ldots \ldots$

Blackfoot River fish populations .............. 41

Headwaters toxic metals problem ............... 43

Native fish species evaluations ............... 44

Tributary stream evaluations ................ 46

MAJOR FISH SPECIES MANAGEMENT PLANS .............. 54

Westslope Cutthroat Trout .................. 54

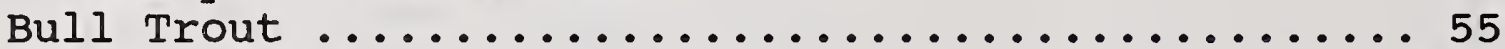

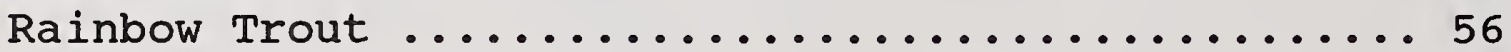

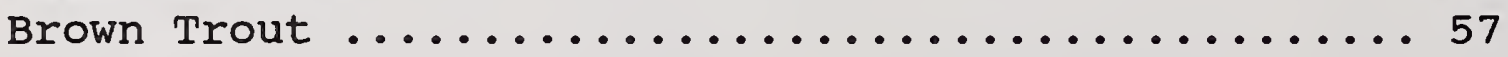

LITERATURE CITED ........................... 59

APPENDIX................................. 


\section{INTRODUCTION AND OBJECTIVES}

The Blackfoot River flows 132 miles in a westerly direction from its source near the continental Divide to its confluence with the clark Fork River at Bonner, Montana. Principle tributary streams in downstream order are: Alice, Landers Fork, Arrastra, Nevada, North Fork, Chamberlain, Monture, Clearwater, Belmont, Gold, and Union Creeks. The Landers Fork, North Fork, clearwater and Monture creek are the largest of the Blackfoot's tributaries, three of which originate in the Lincoln-scapegoat wilderness. The clearwater River does not originate in the wilderness area, and is naturally influenced by the series of lakes through which it flows.

A fishery inventory of the Blackfoot River from headwaters to mouth was conducted during 1988 to evaluate angler concerns of a declining fishery in recent years. The effort emphasized sampling of young-of-the-year trout throughout the Blackfoot River, repeating fish population surveys conducted in the headwaters during the early 1970's, establishing three new population inventory sections, conducting a voluntary creel census, and evaluating species of special concern. In 1989 evaluations of the Blackfoot River focused on identifying fishery characteristics, habitat, and problems in the larger tributary streams. Toxic metals accumulation in trout in the headwaters and long-term population monitoring sections in the Blackfoot River were also evaluated.

Fish populations in the Blackfoot River vary greatly in terms of species composition and overall fish density. The differing fisheries of the Blackfoot River are a product of habitat characteristics, recruitment sources, and human influences such as environmental degradation and fishery exploitation. Fisherman concerns over a declining fishery are centered in the middle and lower reaches of the river, from roughly Nevada creek to the mouth of the Blackfoot River. This report addresses possible reasons for angler dissatisfaction, and identifies potential management strategies to remedy fisheries problems in the Blackfoot River. Fishery management tools including stock enhancement (naturally or artificially), harvest regulation changes, and habitat improvement appear to have potential to improve low fish densities in some reaches of the river. Due to the complexity of the fishery, and the factors that influence it, no single management tool is likely to be successful in correcting problems. 


\section{PROCEDURES}

\section{FIBH BAMPLING}

Fish sampling was conducted at two levels of intensity: the first was a single pass survey and the second a multiple pass population estimate.

Fish populations were estimated using either a mark and recapture method or a two-pass depletion method. Mark-recapture population estimates were calculated using Chapman's modification of the Peterson formula (Ricker 1975). Variance estimates were made using the seber formula (Seber 1982). Maximum-likelihood population estimates were made based upon number of fish captured on each electrofishing run (Van Deventer and Platts 1983). Total length (TL) of captured fish was measured to the nearest $\mathrm{mm}$, and weight was measured to the nearest gram. Trout longer than 8.0 in. TL were tagged with individually numbered T-tags (Floy Tag Co.). All fish handled either received a tag or a fin removal clip identifiable to specific tributary streams (Appendix Table 1).

We duplicated two electrofishing sections sampled in 1988; the scotty Brown bridge and Johnsrud sections (Peters and Spoon 1988). Nineteen of the larger tributaries to the Blackfoot River were also sampled including: Arrastra, Beaver, Belmont, Chamberlain, Clearwater, Copper, Cottonwood, Gold, Lander's Fork, Monture, Nevada Spring Creek, North Fork, Poorman, Rock, Spring, Kleinschmidt, Union and Wales Creek (Figure 1). Fish tissue collections were made at sites on the Blackfoot River including: above Pass Creek, and sites described by spence (1975), Below Pop's Place and Flesher. The fish tissues were analyzed at the University of Montana for metals concentration. Tissue analysis procedures used are described in Moore, Louma, and Peters 1990.

Fish sampling equipment was fitted to the type of water conditions each section presented. In the small stream sections a Coffelt Model BP-1C, gas-powered backpack electrofishing unit was used. We used the wire hoop positive and four multi-strand cables for the negative electrode. We used a Coffelt Model 2C2000 rectifying unit with a 1500 watt gas-powered generator in Nevada creek. Our positive electrode was a hand-held 1-foot diameter hoop with a braided copper wire negative. We used an aluminum drift boat on the North Fork of the Blackfoot River and a jet-powered aluminum river boat on the Johnsrud and scotty Brown bridge sections. Electrofishing gear was mounted similarly on both boats with two boom anodes and the boat used as the cathode. Each anode had four cable droppers. A Coffelt Model VVP-15, and a 3500 watt generator provided the electrical fields necessary for fish sampling. 
Young of the year (YOY) trout densities were surveyed in the tributary streams from August through october. Extra effort was used to sample both stream edges and in edge cover areas to allow comparisons of YOY densities between sections. Tributary YOY sampling was conducted along the entire sampled sections which is different than the 1988 Blackfoot River samples.

\section{BULL TROUT REDD SURVEYS}

In late september bull trout redds were counted in Monture Creek and the North Fork of Blackfoot River. Counts were made by walking along the stream bank through known spawning areas as done in 1988 .

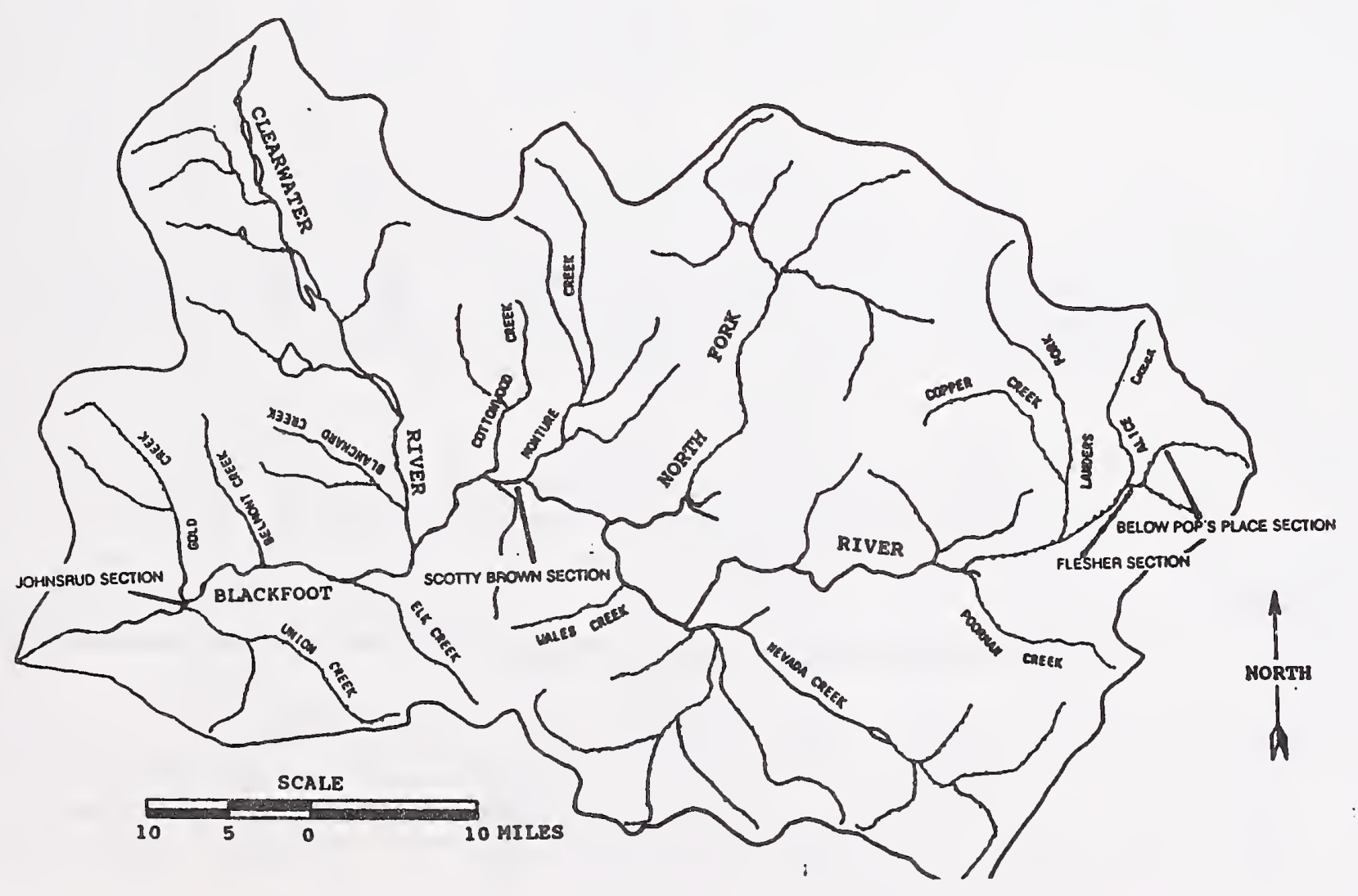

Figure 1. Project study area in the Blackfoot River drainage of western Montana, 1989. 


\section{RESULTS}

\section{Blackfoot River Fish Populations}

\section{Johnsrud Section}

The species composition of trout sampled in the Johnsrud section in June of 1989 was 95.7 percent rainbow, 2.8 percent brown, and 0.7 percent each for bull and cutthroat trout (Table 1).

Rainbow

larger

than 12 inches

TL

(total

length)

declined

from

$45 / 1,000$

ft in

1985 to

$12.5 / 1,0$

$00 \mathrm{ft}$ in

1989.

This

size

group

included

year

classes

of 4 and

older

fish.

Point

estimate

$s$ for

juvenile

fish

segments of the rainbow trout population (size groups 5.0 to 9.9 in. and 10.0 to 11.9 in.) were not significantly different from 1985 to 1989. However the point estimates were both less than the 1985 estimate. Population estimates for rainbow trout larger than 12 inches total length (TL) were significantly lower than the last previous estimate in 1985 (Figure 2).

The Johnsrud section held an estimated 6.4 brown trout, 1.7 bull trout, and 1.7 cutthroat trout larger than 6.0 in. TL per $1,000 \mathrm{ft}$ (Table 1 ). Cutthroat trout larger than 6.0 in $\mathrm{TL}$
Table I Mark and recapture population estimates for the Blackfoot River Johnsrud Section for the years 1989 and 1985.

\begin{tabular}{|c|c|c|c|c|c|c|c|}
\hline $\begin{array}{l}\text { Location } \\
\text { (river mile) }\end{array}$ & $\begin{array}{l}\text { tion } \\
\text { igth } \\
\text { ni) }\end{array}$ & Species & $\begin{array}{l}\text { Size class } M \\
\text { (in) }\end{array}$ & $\begin{array}{l}\text { Marked } \\
\text { (M) }\end{array}$ & $\begin{array}{l}\text { Captured } \\
\text { (C) }\end{array}$ & $\begin{array}{l}\text { Recaptured } \\
\text { (R) }\end{array}$ & $\begin{array}{l}\text { Estimated } / 1,000 \mathrm{ft} \\
(95 \% \text { C.I. })\end{array}$ \\
\hline \multirow[t]{4}{*}{$\begin{array}{l}\text { Johnsrud Section } \\
13.5 \\
\text { June, } 1989\end{array}$} & 3.6 & $\begin{array}{c}\text { Rainbow } \\
\text { trout }\end{array}$ & $\begin{array}{c}(5.0-9.9) \\
(10.0-11.9) \\
\geq 12.0\end{array}$ & $\begin{array}{r}436 \\
68 \\
60\end{array}$ & $\begin{array}{r}392 \\
53 \\
42\end{array}$ & $\begin{array}{c}50 \\
6 \\
10\end{array}$ & $\begin{array}{r}177.1 \pm 42.2 \\
28.9 \pm 17.1 \\
12.5 \pm 5.6\end{array}$ \\
\hline & & $\begin{array}{l}\text { Brown } \\
\text { trout }\end{array}$ & $\geq 6.0$ & 43 & 35 & 12 & $6.4 \pm 2.3$ \\
\hline & & $\begin{array}{l}\text { Bull } \\
\text { trout }\end{array}$ & $\geq 6.0$ & 16 & 12 & 7 & $1.7 \pm 0.4$ \\
\hline & & $\begin{array}{l}\text { Cutthroa } \\
\text { trout }\end{array}$ & at $\geq 6.0$ & 13 & 6 & 2 & $1.7 \pm 1.1$ \\
\hline \multirow[t]{4}{*}{$\begin{array}{l}\text { Johnsrud Section } \\
13.5 \\
\text { June, } 1985\end{array}$} & 3.6 & $\begin{array}{l}\text { Rainbow } \\
\text { trout }\end{array}$ & $\begin{array}{l}(5.0-9.9) \\
(10.0-11.9) \\
\geq 12.0\end{array}$ & $\begin{array}{r}470 \\
122 \\
78\end{array}$ & $\begin{array}{r}448 \\
95 \\
53\end{array}$ & $\begin{array}{r}60 \\
15 \\
6\end{array}$ & $\begin{array}{r}181.0 \pm 27 \\
38.0 \pm 11 \\
45.0 \pm 21\end{array}$ \\
\hline & & $\begin{array}{l}\text { Brown } \\
\text { trout }\end{array}$ & $\geq 6.0$ & 22 & 14 & 2 & - \\
\hline & & $\begin{array}{l}\text { Bull } \\
\text { trout }\end{array}$ & $\geq 6.0$ & 16 & 8 & 1 & - \\
\hline & & $\begin{array}{l}\text { Cutthroat } \\
\text { trout }\end{array}$ & $t \geq 6.0$ & 58 & 56 & 16 & $10.0 \pm 3$ \\
\hline
\end{tabular}


declined from 10.0/1,000 ft in 1985 to $1.7 / 1,000 \mathrm{ft}$ in 1989.

Scotty Brown Bridge

Section

The species

composition of sampled trout in June of 1989

was 61.5 percent

rainbow, 29.8 percent brown, and 4.2 percent bull and 4.5 percent cutthroat trout (Table 2 ). One marking and one recapture run were required to obtain a population estimate in the Scotty Brown section in June of 1989.

The estimated population of all trout species larger than 4.0 in. TL was $61.4 / 1,000$

ft. The first fish population estimate obtained in this section was in the fall of 1988. There was no significant changes in the dominant rainbow population between the two sampling dates (Figure 3). The Scotty Brown Bridge section held an estimated 36 rainbow trout larger than 4.0 in. TL per 1,000 ft. In addition estimated numbers of brown trout larger

than 6.0 in. $T L$ equaled $23.1 / 1,0$ $00 \mathrm{ft}$ and bull trout larger than 6.0 in. $T L$, $2.3 / 1,00$ $0 \mathrm{ft}$.

\section{BLACKFOOT RIVER JOHNSRUD SECTION}

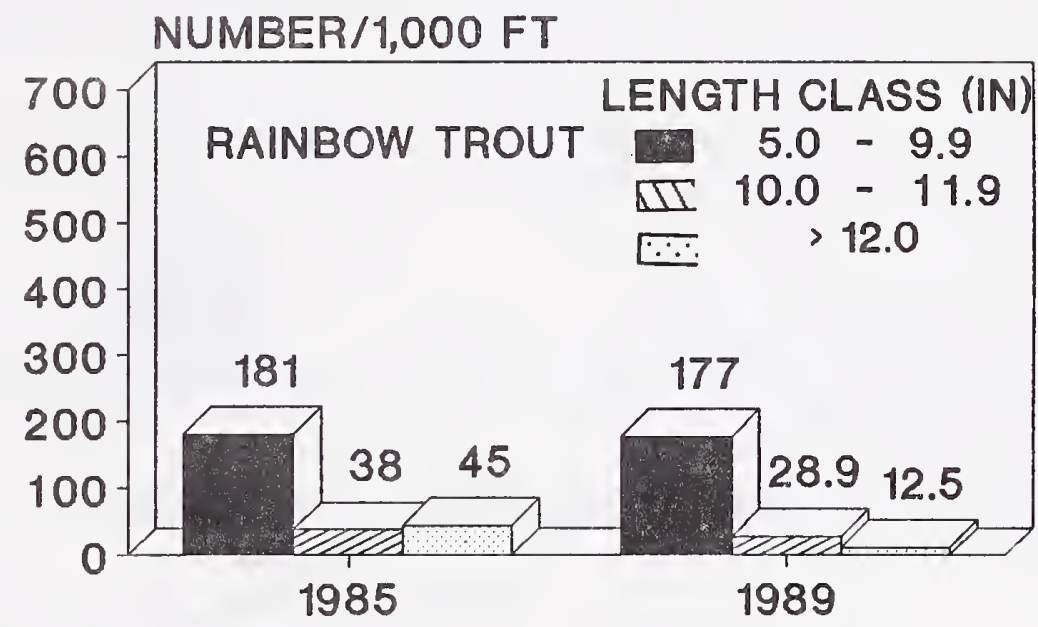

Figure 2. Comparison of population estimates on the Blackfoot River, Johnsrud section between the years 1985 and 1989.
Table II. Trout population estimates on the Blackfoot
River, Scotty Brown section, June, 1989.

\begin{tabular}{|c|c|c|c|c|c|c|c|}
\hline $\begin{array}{l}\text { Location } \\
\text { (river mile) }\end{array}$ & $\begin{array}{l}\text { Section } \\
\text { length } \\
\text { (mi) }\end{array}$ & Species & $\begin{array}{l}\text { Size class } \\
\text { (in) }\end{array}$ & $\begin{array}{l}\text { Marked } \\
(\mathrm{M})\end{array}$ & $\begin{array}{l}\text { Captured } \\
\text { (C) }\end{array}$ & $\begin{array}{l}\text { Recaptured } \\
\text { (R) }\end{array}$ & $\begin{array}{l}\text { Estimated } / 1,000 \mathrm{ft} \\
\qquad(95 \% \mathrm{C}>1 .)\end{array}$ \\
\hline \multirow[t]{3}{*}{$\begin{array}{l}\text { Scotty Brown } \\
(43.5) \\
\text { June, } 1989\end{array}$} & 3.8 & $\begin{array}{l}\text { Rainbow } \\
\text { trout }\end{array}$ & $\begin{array}{c}(4.0-10.9) \\
(11.0-13.9) \\
\geq 14.0\end{array}$ & $\begin{array}{r}106 \\
25 \\
16\end{array}$ & $\begin{array}{r}101 \\
27 \\
13\end{array}$ & $\begin{array}{r}18 \\
6 \\
4\end{array}$ & $\begin{array}{c}28.6 \pm 10 \\
5.1 \pm 2 \\
2.3 \pm 1\end{array}$ \\
\hline & & $\begin{array}{l}\text { Brown } \\
\text { trout }\end{array}$ & $\geq 6.0$ & 7 & 61 & 9 & $23.1 \pm 12$ \\
\hline & & $\begin{array}{l}\text { Bull } \\
\text { trout }\end{array}$ & $\geq 6.0$ & 13 & 9 & 2 & $2.3 \pm 1$ \\
\hline
\end{tabular}


Movements of Tagged Fish

We tagged 323

rainbow, 286 brown, 54 bull, and 41 cutthroat trout in the Blackfoot drainage in 1989. Most of the tagged fish were captured and tagged in the scotty Brown and Johnsrud sections. Anglers returned 36 tags and our fish population sampling recovered another 37 tags (excluding population estimate sampling recaptures).

Forty two of the 44 rainbow tag returns revealed no significant movement from the initial tagging location (Table 3). The other 2 rainbows moved farther than 10 miles.

Twenty one of 24 brown trout tag returns showed no significant movement from the initial tagging location. Three brown trout moved 2 to 5 miles from the initial tag site.

Four bull trout tag returns were obtained. One adult bull trout tagged in the Johnsrud section in June, 1989 was recovered by an angler in August in the North Fork of the Blackfoot. The bull trout had traveled 52 miles upstream.

\section{BLACKFOOT RIVER \\ SCOTTY BROWN SECTION}

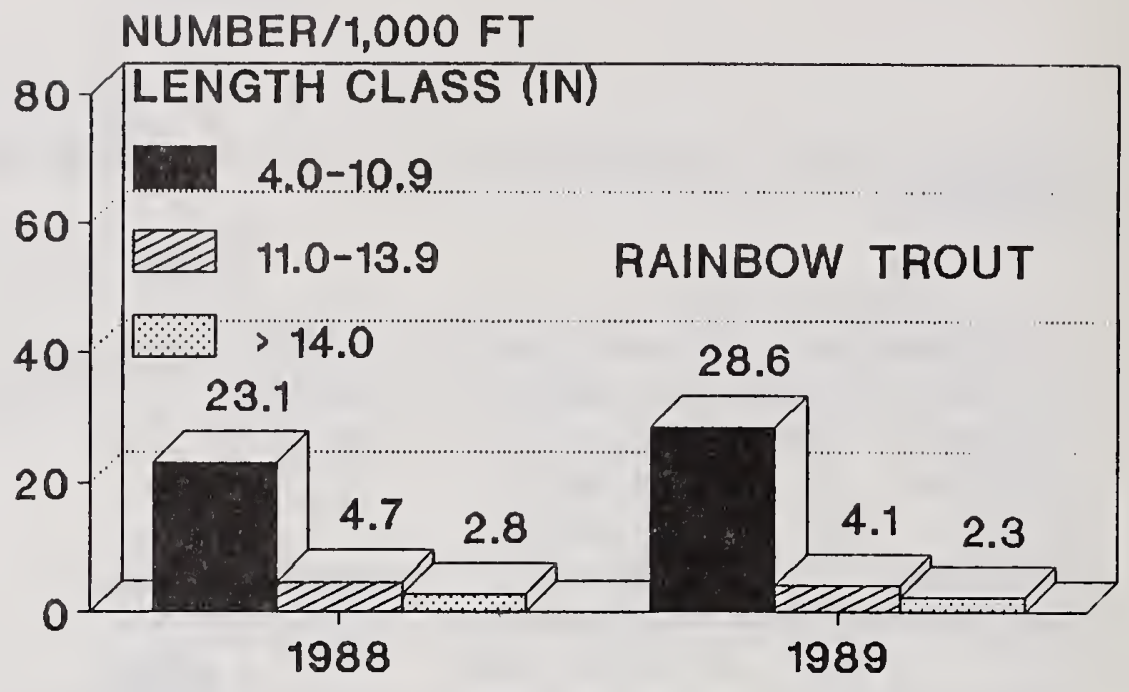

Figure 3. Comparison of population estimates of rainbow trout in the Blackfoot River, scotty Brown section for the years 1988 and 1989.
Table III. Summary of tab returns from anglers and electrofishing surveys from fish tagged in the scotty Brown and Johnsrud sections in 1988 and 1989.

\begin{tabular}{|c|c|c|c|c|c|c|}
\hline & Seaso & Season & & Moveme & ent (mile & \\
\hline Species & tagged & recaptured 0 & $0-1.9$ & $2.0-4.9$ & $5.0-9.9$ & $>10.0$ \\
\hline \multirow[t]{4}{*}{ Rainbow } & fall $/ 88$ & spring/89 & 19 & 0 & 0 & 0 \\
\hline & fall $/ 88$ & summer/89 & 1 & 0 & 0 & 0 \\
\hline & spring/8 & 39 summer/89 & 20 & 0 & 0 & 2 \\
\hline & spring/8 & 39 fall/89 & 2 & 0 & 0 & 0 \\
\hline \multirow[t]{3}{*}{ Brown } & fall/88 & spring/89 & 17 & 0 & 0 & 0 \\
\hline & spring/8 & 39 summer/89 & 3 & 2 & 0 & 0 \\
\hline & fall/88 & fall/89 & 1 & 1 & 0 & 0 \\
\hline Cutthroat & fall/88 & spring/89 & 1 & 0 & 0 & 0 \\
\hline \multirow[t]{3}{*}{ Bull } & fall/88 s & spring/89 & 1 & 0 & 0 & 0 \\
\hline & spring/8 & 9 summer/89 & 1 & 0 & 0 & 1 \\
\hline & fall $/ 8$ & fall/89 & 1 & 0 & 0 & 0 \\
\hline
\end{tabular}

Headwaters Toxic Metals Problem 


\section{Trout Population and Liver Metals Concentration}

The cutthroat trout population in the Flesher section, river mile 124.5, of the Blackfoot River declined significantly since the tailings pond failure at the Mikehorse Mine site in June, 1975. An estimated 69 age I and older cutthroat per 1,000 ft inhabited the area in 1973 (Figure 4). Immediately following the pond failure in 1975 their numbers had declined to an estimated density of 30/1,000 ft. In 1988 further decline in the cutthroat population was evident with an estimated density of 15/1,000 ft.

Young-of-the-year

(YOY) cutthroat could not be found in the section following the tailings pond failure (Figure 5). In 1973 the section held an estimated 187 YOY per $1,000 \mathrm{ft}$. In 1988 only 2 YOY were observed in two electrofishing passes in the section. Cadmium concentrations in cutthroat liver tissues averaged $8.9 \mathrm{ug} / \mathrm{g}$ in the Below Pop's Place section (river mile 129.0) and $5.9 \mathrm{ug} / \mathrm{g}$ in the Flesher section (river mile 125.0) in 1989 (Table 4). only six brook trout were captured at river mile 132, an area severely impacted by bedload/tailings deposition after the Mike horse tailings pond failure. averaged $18 \mathrm{ug} / \mathrm{g}$ dry weight.

Large brown trout at river mile 106 near the town of Lincoln carried over 10 times more cadmium in liver tissues compared to brown trout at river mile 27. The liver concentrations of cadmium at river mile 106 averaged $0.83 \mathrm{ug} / \mathrm{g}$ dry weight.
Table IV. Metals concentration in trout liver tissue from the Blackfoot River and Marshall Creek, 1988 and 1989 (from Moore, Louma, and Peters, 1990).

\begin{tabular}{|c|c|c|c|c|}
\hline $\begin{array}{r}\text { Sam } \\
\text { si }\end{array}$ & $\begin{array}{c}\text { Sample } \\
\text { size }\end{array}$ & $\begin{array}{l}\text { Cadmium } \\
\text { (ug/g dry) }\end{array}$ & $\begin{array}{c}\text { Copper } \\
\text { (ug/g dry) }\end{array}$ & $\begin{array}{c}\text { Zinc } \\
\text { (ug/g dry) }\end{array}$ \\
\hline \multicolumn{5}{|c|}{ mall cutthroat $(2.7-12.4$ in $T L)$} \\
\hline $\begin{array}{l}\text { larshall Creek } \\
\text { lackfoot rm } 27 \\
\text { lackfoot rm } 118 \\
\text { lackfoot rm } 125 \\
\text { lackfoot rm } 129\end{array}$ & $\begin{array}{c}18 \\
2 \\
11 \\
3 \\
2\end{array}$ & $\begin{array}{l}0.18 \pm 0.07 \\
0.13 \pm 0.16 \\
0.21 \pm 0.21 \\
5.90 \\
8.90\end{array}$ & $\begin{array}{l}715 \pm 6 \\
38 \pm 32 \\
15 \pm 7 \\
22 \pm 18 \\
34 \pm 18 \\
24\end{array}$ & $\begin{array}{l}109 \pm 3 \\
111 \pm 22 \\
116 \pm 7 \\
146 \pm \\
135\end{array}$ \\
\hline
\end{tabular}

Small brook trout $(4.0-8.0$ in $T L)$

Blackfoot rm132 $618.00 \pm 131,113 \pm 51654 \pm 68$

Large brown trout $(13.4-18.7$ in $\mathrm{TL})$

Blackfoot rm27 $6 \quad 0.07 \pm 0.05494 \pm 223 \quad 111 \pm 9$ $\begin{array}{lllll}\text { Blackfoot rm } 106 & 12 & 0.83 \pm 0.42846 \pm 398 & 111 \pm 10\end{array}$

Native Fish Species Evaluation

Bull Trout Redd Surveys 
Redd counts were completed on known spawning areas in the North Fork and Monture Creek in 1989. A total of 8 redds in a 5 mile long section were counted in Monture creek and 11 redds in the North Fork in a 4 mile long section.

\section{Bull Trout Densities}

Population estimates of bull trout larger than 6 inches in the Blackfoot River were completed in the Scotty Brown and Johnsrud section in June, 1989 (Tables 1 and 2). The Scotty Brown Section held a density of 0.12 bull trout per 1,000 ft. The Johnsrud Section held an estimated density of $0.09 / 1,000 \mathrm{ft}$.

of 19 major tributary

streams sampled in 1989, only the North Fork contained significant numbers of YOY bull trout.

Young-of-the-year (YOY) densities in the North Fork ranged from 0.12 to 0.33 per $10 \mathrm{ft}$ of stream length (Appendix Table 2). One sampled section of copper creek had a density of $0.21 / 10 \mathrm{ft}$ YOY bull trout. Monture Creek had the next best densities of 0.03 to $0.07 / 10 \mathrm{ft}$ in a known historically good spawning area.

our sampling failed to find any YOY bull trout in the Landers Fork, Arrastra Creek, Rock Creek, and cottonwood Creek which were known to have spawning bull trout in the past.

Bull trout densities are greater in the upper reaches of tributaries than in the lower reaches (Appendix Tables 2 and 3).

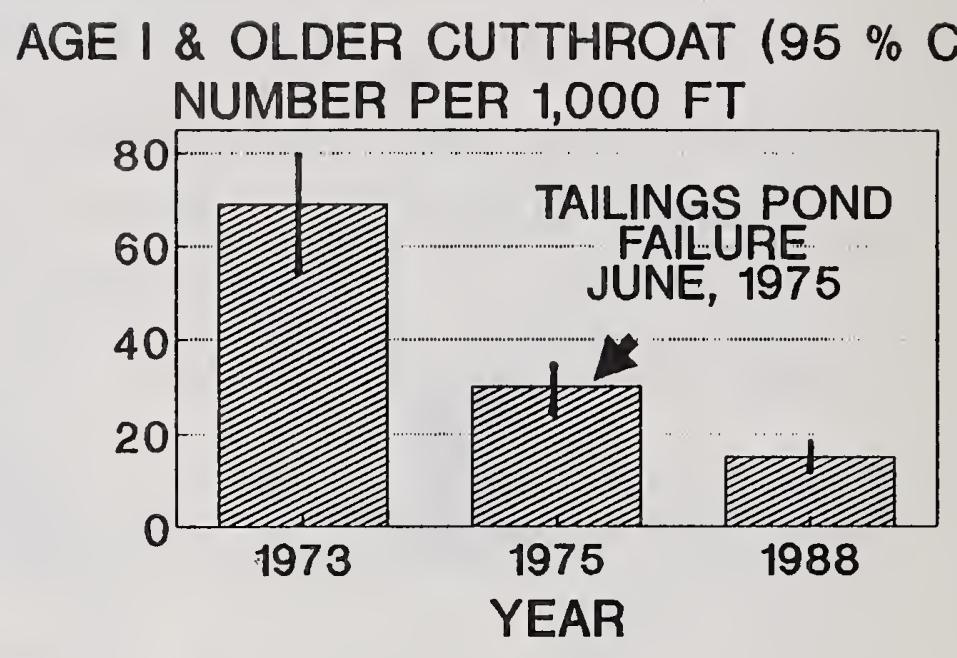

Figure 4. Comparison of age I and older cutthroat population estimates in the Blackfoot River, Flesher section for the years 1973, 1975, and 1988.

\section{AGE 0 CUTTHROAT (95 \% C.I.)}

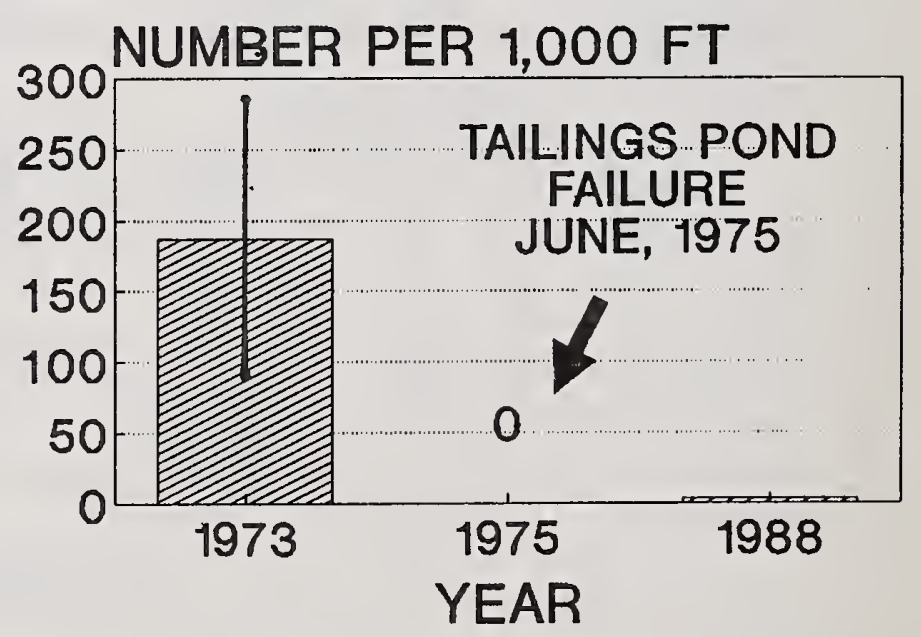

Figure 5. Comparison of youngof-the-year cutthroat population estimated in 1973 to the fish samples collected in 1975 and 1988. 
Low densities of cutthroat trout in the Blackfoot River and tributaries prevent adequate sampling for good population estimates except for a few select sites.

cutthroat densities are generally greater in the upper reaches of tributaries compared to the lower reaches (Appendix Table 3).

The highest densities of cutthroat were found in Chamberlain Creek, the headwaters of Gold Creek and Poorman Creek (Appendix Tables 3 and 4 ).

Cutthroat trout in the 3 year old year class were captured in the Scotty Brown and Johnsrud section in spring of 1989. No YOY cutthroat have been captured in the Blackfoot River below Lincoln.

Tributary Stream Evaluation

Dominant Fish Species Distribution

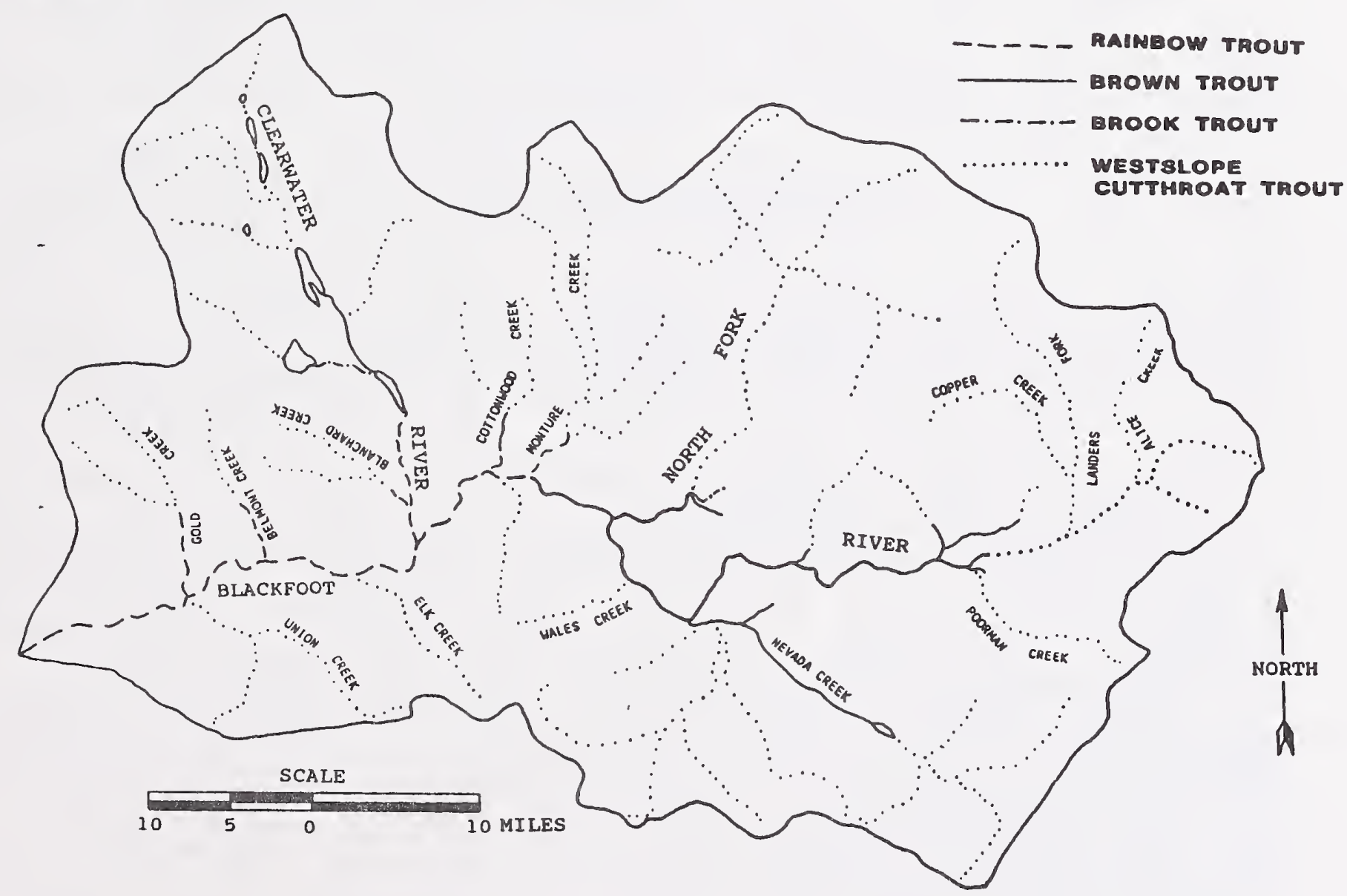

Figure 6. Distribution of dominant trout in the Blackfoot River basin. 
Cutthroat trout dominated headwater and middle reaches of most sampled tributary streams (Figure 6). Rainbow trout dominated the lower Blackfoot River from Monture Creek to the mouth. Rainbow trout were also dominant in the lower Gold, lower Belmont, lower Monture, and the clearwater River. Brown trout dominated the lower reaches of some tributary streams and the Blackfoot River from Monture creek to Lincoln. The tributaries which were dominated by brown trout in their lower reaches included: Beaver, Cottonwood, Spring, Nevada, and Arrastra creeks.

The headwaters of most streams draining to the Blackfoot River from the north have characteristically steep forested upper basins. The steep forested upper basin drains mostly very old and resistant glaciated Belt rock mountains. Through these ancient sedimentary beds, the upper creeks often occupy U-shaped glacial valleys. Lower stream reaches of these northern Blackfoot tributaries commonly flow through outwash and moraine.

\section{Arrastra Creek}

Arrastra creek, a second order stream, drains the western slopes of Arrastra Mountain on the Helena National Forest in Powell county. The stream flows south 13 miles through a glaciated mountain valley and discharges into the Blackfoot River at river mile 88.8 .

Ingress is unrestricted on the upper basin on National Forest Land. The mid to lower basin consists of mostly private land. An unimproved dirt road parallels the lower creek for 5.5 miles upstream from the mouth and is in private ownership. Basin land uses include commercial timber harvest, commercial outfitting, recreation and ranching.

The upper basin supports subalpine forests of Englemann spruce, lodgepole pine, and subalpine fir. With decreasing elevation, Douglas fir and ponderosa pine become dominant. Riparian vegetation ranges from a spruce forest in the headwaters to deciduous shrubs near the mouth.

The stream is perennial in upper reaches but loses water to alluvial outwash in mid reaches where it becomes intermittent. At about mile 2 to 2.5 , the stream gains water and remains perennial to its mouth. Stream discharge of Arrastra Creek was 16.9 cfs near the mouth on August 23, 1989 (Appendix Table 5).

stream gradient ranges from over 200 feet per mile in the upper reach to about 6 feet per mile near the mouth (Figure 7). Fish habitat ranges from cascading bouldery reaches in the upper basin to beaver impounded reaches with heavily silted gravels near the mouth. At stream mile 9.2 the gradient increases and substrates become less silted. Large amounts of woody debris and undercut banks provide high quality fish habitat in this upper reach.

In August 1989, fish sampling produced no fish in a headwater section above forest road 4104 , stream mile 9.8 . 


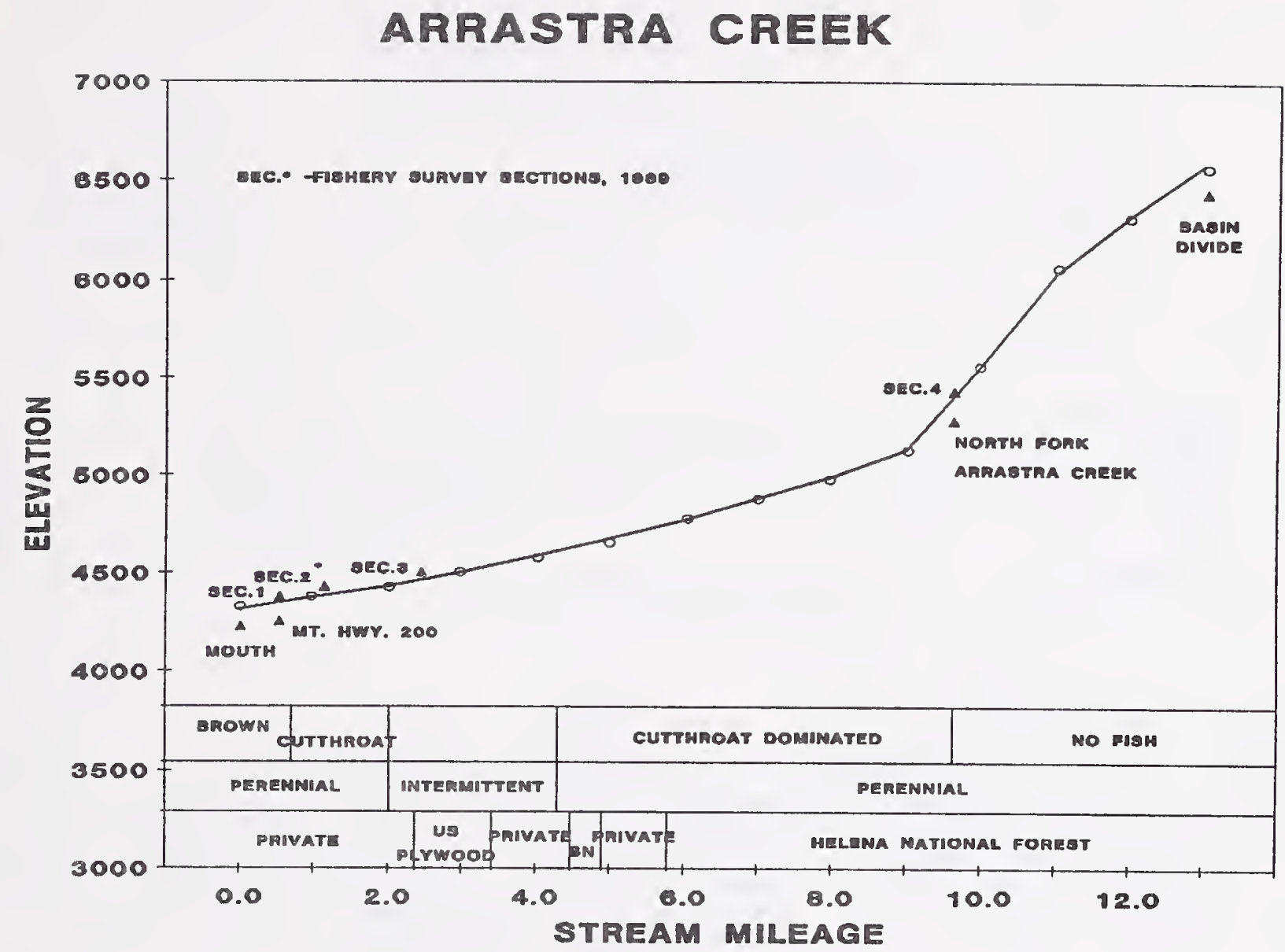

Figure 7. Stream channel gradient, land ownership, dominant trout species, stream flow characteristics, and fish sampling sections in Arrastra Creek.

Fishery surveys in three sections in the lower perennial reach produced mostly brown trout followed by brook trout, cutthroat and bull trout respectively (Appendix Table 3). Other fish observed included mountain whitefish, longnose sucker and sculpin.

Brown trout primarily inhabit the lower perennial reach where the gradient moderates. Two brown trout redds were observed on November 2, 1989 in a survey from the HWY 200 bridge upstream one half mile (stream mile 0.5 to 1.0 ). Only brown trout YOY were captured at stream mile 0.5 in a density of $0.61 / 10 \mathrm{ft}$ (Appendix Table 2). YOY of cutthroat, brown, and brook trout were captured in densities ranging from 0.21 to $0.26 / 10 \mathrm{ft}$ at stream mile 1.1. No YoY were captured at stream mile 2.4.

Electrophoretic analysis of westslope cutthroat by Leary and Allendorf in 1989 indicated the drainage supported pure strain westslope cutthroat trout. 
BEAVER CREEK

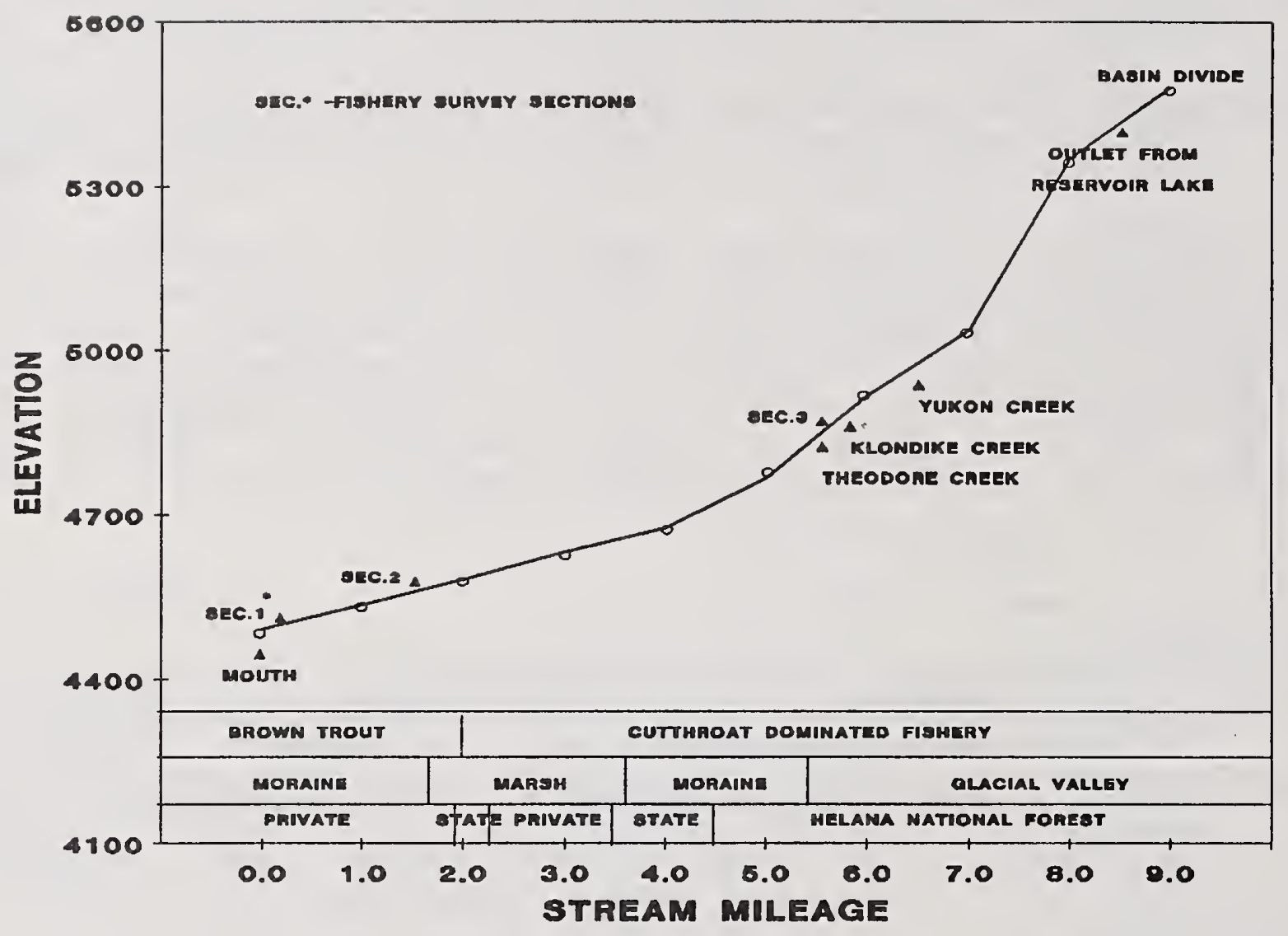

Figure 8. Stream channel gradient, land ownership, dominant trout species, stream flow characteristics, and fish sampling sections in Beaver Creek.

\section{Beaver Creek}

Beaver Creek is a third order tributary to Keep cool creek. It begins near Arrastra Mountain northwest of Lincoln in Lewis and Clark, and Powell counties. The source of Beaver Creek is Reservoir lake (elev. 5460). From this source it flows south nine miles to its confluence with Keep Cool Creek (elev. 4490).

Beaver Creek begins in the Helena National Forest, then flows onto state and private lands. Basin land uses include commercial timber harvest, ranching, farming and recreation. Housing developments parallel the stream at the lower end.

The forested upper valley originated during glacial times. An alpine glacier scoured out reservoir lake, and the wide lower valley from the parent sedimentary Belt rock. In the lower basin today the stream enters a beaver impounded reach, and then 
becomes slightly entrenched in a rolling glacial till plain.

Beaver Creek maintains a moderate gradient, ranging from 270 feet per mile below the reservoir to 45 feet per mile near the mouth (Figure 8). Discharge was $10.7 \mathrm{cfs}$ one half mile above the mouth on August 31, 1989 (Appendix Table 5).

The stream's riparian vegetation ranges from a spruce dominated woodland with alder, red osier dogwood, and rushes in the undergrowth in the headwaters. Dense stands of alder and willow-dominated shrubs with sedges along the water edge dominate the riparian vegetation near the mouth.

The riparian vegetation, channel debris and undercut banks, provide excellent stream cover.

At stream mile 5.4 cutthroat dominated the population and brook and brown trout comprised less than $10 \%$ of the population (Appendix Table 3). In the middle reaches, the fishery is dominated by brown and brook trout. Brown trout dominate the fishery near the mouth.

The estimated brown trout density near the mouth was 180 brown trout per 1000 feet of stream (Table 5). Few YOY brown trout were captured.

six small redds were observed in a $0.66 \mathrm{mile}$ section near the mouth on November 2, 1989. The redds were gravelly with moderate to heavy amounts of sand and silt present.

A survey of the upper cutthroat fishery produced only two cutthroat YOY out of 84 fish collected in a 284 foot section (Appendix Table 3).

Genetically pure

strains of westslope cutthroat trout dominate the upper fishery (Leary and Allendorf, 1989).

Table $v$. Age class population estimates for brown trout in Beaver Creek near the mouth, August, 1989.

\begin{tabular}{|c|c|c|c|c|}
\hline $\begin{array}{l}\text { Age } \\
\text { class }\end{array}$ & $\begin{array}{l}\text { Length } \\
\text { class } \\
\text { (in) }\end{array}$ & $\begin{array}{l}\text { Number } \\
\text { captured }\end{array}$ & $\begin{array}{l}\text { Mean } \\
\text { length } \\
\text { (in) }\end{array}$ & $\begin{array}{l}\text { Estimated number } \\
\text { per } 1,000 \mathrm{ft} \\
(95 \% \text { C.I.) }\end{array}$ \\
\hline $\begin{array}{l}\text { YOY } \\
\text { I } \\
\text { II } \\
\text { III }\end{array}$ & $\begin{array}{c}\leq 3.1 \\
3.1-6.9 \\
6.9-10.8 \\
10.8-12.4\end{array}$ & $\begin{array}{c}3 \\
34 \\
33 \\
6\end{array}$ & $\begin{array}{c}2.4 \\
5.4 \\
8.5 \\
11.7\end{array}$ & $\begin{array}{c}4 \\
92 \pm 38 \\
71 \pm 12 \\
13 \\
\text { Total } 180\end{array}$ \\
\hline
\end{tabular}

\section{Belmont creek}

Belmont creek, a second-order stream, originates on the Lolo National Forest and Champion International Timber Lands near Gold Creek Peak and Belmont Peak in Missoula county. It drains moderate to steeply sloping belt rock mountain slopes. Belmont Creek flows 11 miles southeast through a checkerboard ownership pattern of public and private lands before entering the Blackfoot River at river mile 21.9 .

Stream discharge of was 13 cfs near its mouth on August, 1989 (Appendix Table 5).

The basin supports commercial forests of Douglas fir, ponderosa pine, lodgepole pine and western larch. Forest access roads parallel Belmont creek over most of its length. Basin land 
uses include commercial timber harvest, livestock grazing, ranching and recreation.

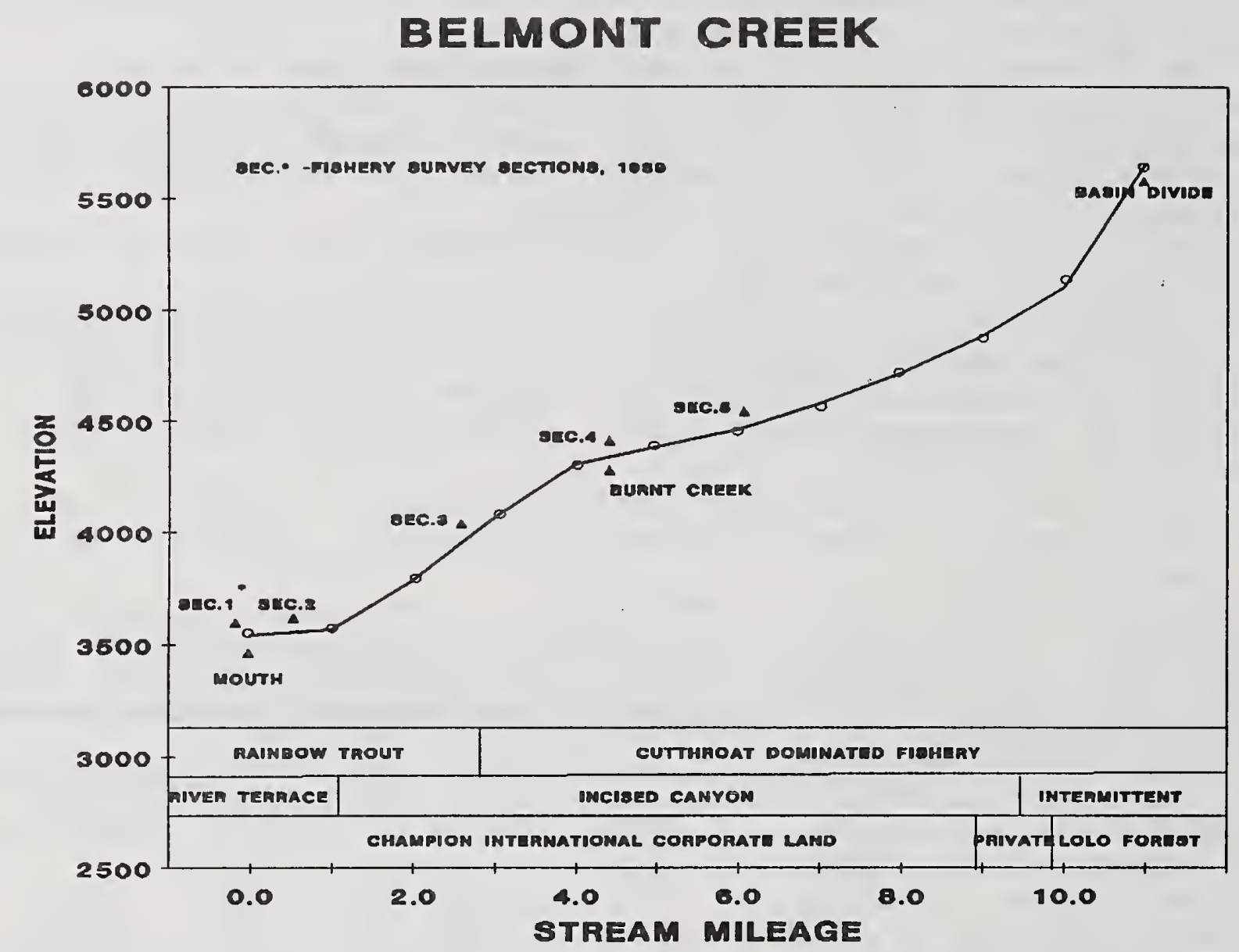

Figure 9. Stream channel gradient, land ownership, dominant trout species, stream flow characteristics, and fish sampling sections in Belmont Creek.

Belmont Creek's physical characteristics vary with elevation and reach (Figure 9). The incised upper reach maintains a steep gradient of about 220 feet per mile. The gradient moderates to 80 feet per mile in the middle section. Logging debris and beaver impoundments are common in the middle reaches where stream bottom substrates consist of silt and gravels. At about stream mile 4.0 the gradient increases to 240 feet per mile. The stream channel is incised and water flow turbulent in this reach. The cascading stream produces good pools and only moderately silted substrates. The gradient moderates near the mouth just before entering the Blackfoot River.

In upper reaches, the riparian vegetation consists of an Englemann spruce dominated woodland with a dense undergrowth of alder, willow, chokecherry, fireweed, rose and thimbleberry. The vegetation changes to a mixed woodland dominated by alder, willow 
and chokecherry near the mouth.

The lower

Table VI.

Population estimate for trout

reach provides

some good juvenile

and adult fish

habitats due

primarily to dense

bank vegetation,

the large woody

debris and large

boulders within

the channel.

Belmont Creek

supports

populations of

larger than $3.5 \mathrm{in.} \mathrm{TL}$ in Belmont Creek, 0.6 miles from the mouth, October 19, 1989.

brown trout,

rainbow trout,

cutthroat trout,

bull trout and

mountain whitefish.

Rainbow, bull and

possibly cutthroat

trout in the Blackfoot

River use Belmont Creek

for spawning and early

rearing. Rainbow trout

dominate the fishery

below stream mile 3.0 .

Westslope cutthroat

trout and bull trout

dominate the fishery

upstream from stream

mile 6.0 (Appendix

Table 3). Sculpins

were found throughout

Belmont creek. No

brook trout were found

in any of the sampled

sections. Near the

\begin{tabular}{lcccccc}
$\begin{array}{c}\text { Number } \\
\text { captured }\end{array}$ & $\begin{array}{c}\text { Mean } \\
\text { length } \\
\text { (in) }\end{array}$ & $\begin{array}{c}\text { Length } \\
\text { range } \\
\text { (in) }\end{array}$ & $\begin{array}{c}\text { Mean } \\
\text { weight } \\
\text { (lbs) }\end{array}$ & $\begin{array}{c}\text { Weight } \\
\text { range } \\
\text { (lbs) }\end{array}$ & $\begin{array}{c}\text { Number estimated } \\
\text { per } 1,000 \mathrm{ft} \\
(95 \% \text { C.I.) }\end{array}$ \\
\hline $\begin{array}{l}\text { Species } \\
\begin{array}{l}\text { Rainbow } \\
\text { trout }\end{array}\end{array}$ & 87 & 6.0 & $3.8-9.6$ & 0.12 & $0.03-0.36$ & $192 \pm 14$ \\
$\begin{array}{l}\text { Bull } \\
\text { trout }\end{array}$ & 8 & 7.5 & $6.5-9.0$ & 0.15 & $0.10-0.23$ & 6 \\
$\begin{array}{l}\text { Brown } \\
\text { trout }\end{array}$ & 1 & 12.0 & - & 0.66 & - & \\
& & & & & &
\end{tabular}

mouth Belmont Creek

supports about 225 YOY

trout and

approximately 210 one

YOUNG-OF-THE-YEAR

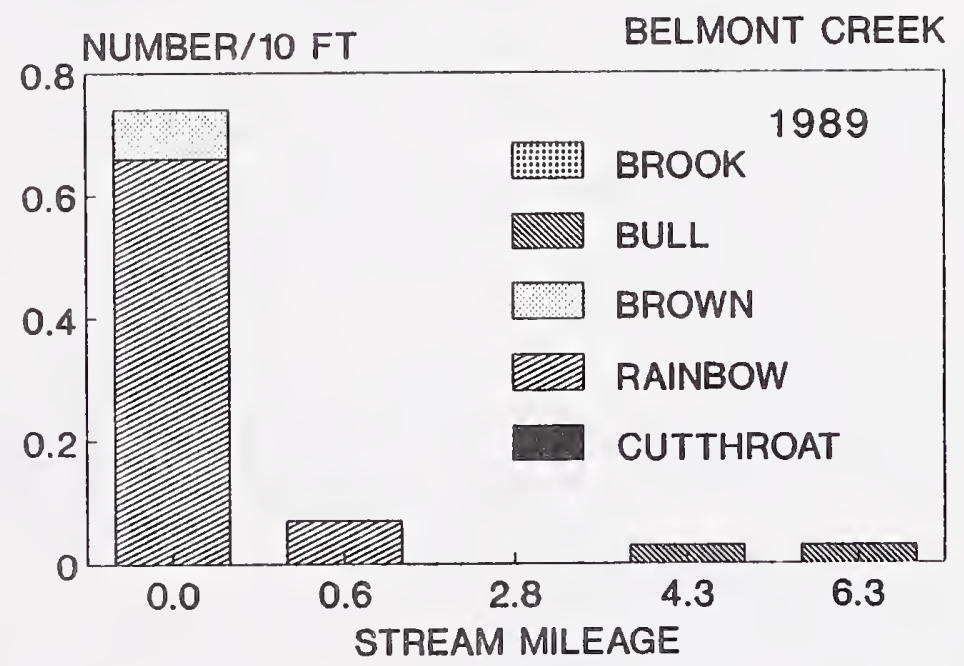

Figure 10. Density of young-of-the-year trout per $10 \mathrm{ft}$. of stream length at sampled locations in Belmont creek.

year old and older fish

per 1000 feet of stream (Table 6 and Figure 10).

Belmont creek held considerably fewer YOY rainbow trout than Gold Creek (Appendix Table 2). Gold Creek had a maximum density of 5.7 YOY rainbow trout/10 ft versus Belmont Creek's $0.66 / 10 \mathrm{ft}$. The highest density found in Belmont creek was in a section below the main road culvert near the mouth in an area with known concentrations of rainbow spawners. 


\section{Chamberlain Creek}

Chamberlain creek, a second order stream originates in Powell County. It flows north from Chamberlain Meadows in the Garnet Mountain range, and enters the Blackfoot River at river mile 43.9, 1.5 miles downstream from Scotty Brown Bridge.

On November 3, 1989 stream discharge of Chamberlain creek was 2.1 cfs.

Most of the upper basin is public land administered by the BLM although Plum Creek and Champion International control commercial timber land in the basin as well. Ingress is unrestricted in these areas. However, road closures beginning at the West Fork, seasonally restrict access to walk-in types of recreation. The lower basin is privately owned. The main road parallels Chamberlain creek from stream mile 2.7 to the confluence of the West Fork at stream mile 3.9.

\section{CHAMBERLAIN CREEK}

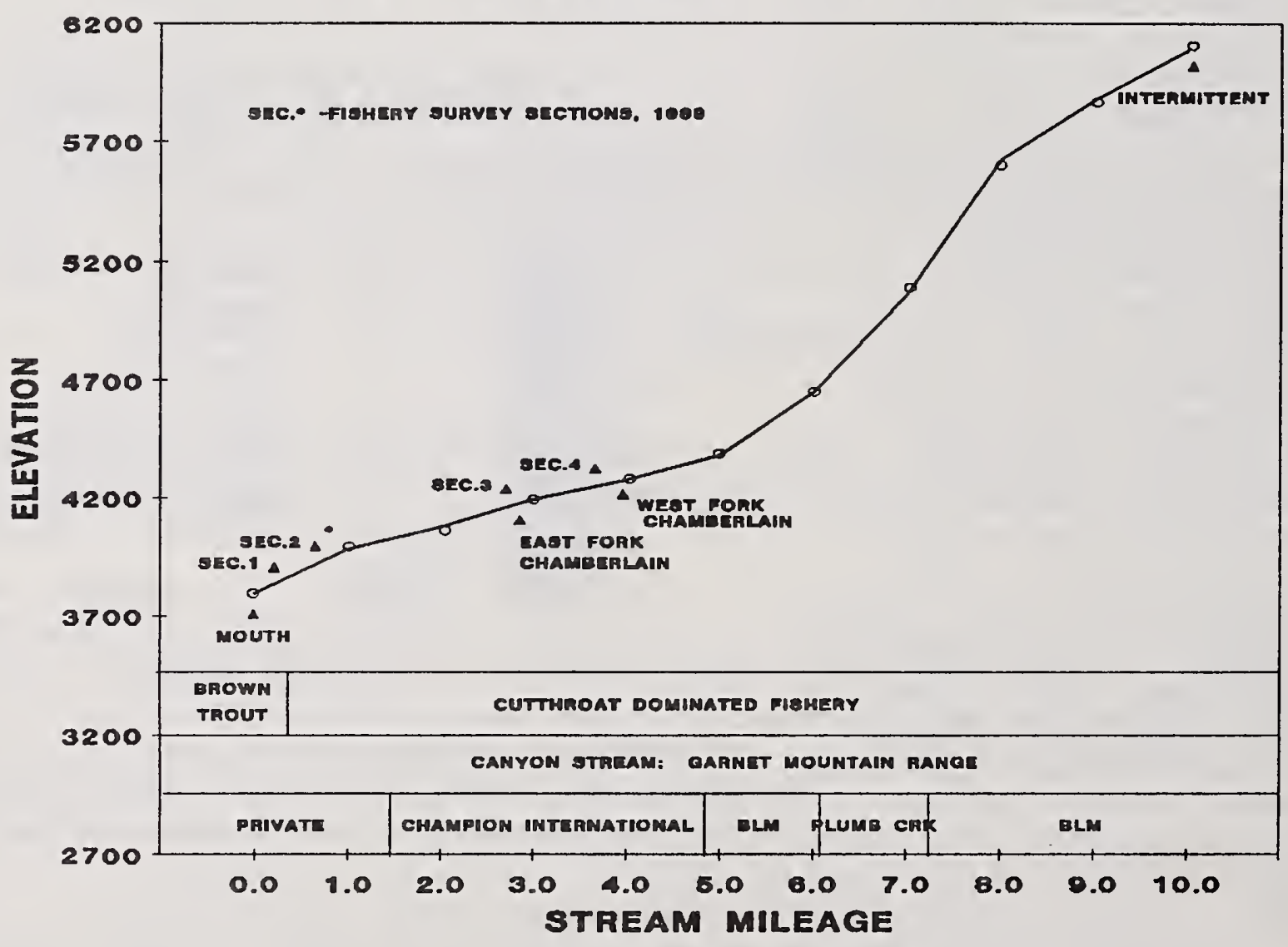

Figure 11. Stream channel gradient, land ownership, dominant trout species, stream flow characteristics, and fish sampling sections in Chamberlain creek. 
Gradient of the Chamberlain Creek channel averages 118 $\mathrm{ft} / \mathrm{mile}$ from the mouth to stream mile 5.2 (Figure 11). Upstream of stream mile 5.2 gradient increases abruptly to an average of $301 \mathrm{ft} / \mathrm{mi}$ to stream mile 8.0. Gradient moderates slightly above stream mile 8.0 to the source.

The riparian vegetation in the upper reaches consist of a spruce canopy with an alder sub-canopy. Nettles and grasses occupy the undergrowth layer. Cottonwood, alder and willow comprise the bulk of the vegetation in the lower reach. Willows are dominant near the mouth where the stream and its flood plain become slightly entrenched in outwash deposits. Over much of its course, overgrazing and trampled banks have damaged the riparian, causing the stream to take on a wide and shallow profile. In the spring of 1990 the West Fork was noticeably more turbid than Chamberlain Creek at it's confluence with Chamberlain creek. Below the West Fork, adult fish habitat is limiting due to channel alterations and bank trampling. Some good habitat exists where riparian debris and undercut banks provide cover. Where habitat is available, it appears fully occupied. The stream has good spawning gravels, although moderately silted, and good habitat for juvenile fish.

Chamberlain creek held the highest densities of trout found in any of the Blackfoot River tributaries (Appendix Tables 3 and 4).

On September 20 and 21, 1989, a population survey at the confluence of the West Fork (mile 3.8) revealed a westslope cutthroat trout population of $967 \mathrm{fish}$ per 1000 feet of stream and much lower densities of brook and brown trout (Appendix Table 4 and Figure 12). No bull trout were found in this or any of the other three sampled sections. YOY densities of cutthroat progressively increased from stream mile 0.5 to 3.8 to a maximum density of 2.87 YOY/10 ft (Figure 13).

One half mile above the mouth, the channel has been bulldozed and dammed with the water diverted into a recently constructed pond. Some water seeps through the diversion dam into the main channel providing low perennial flow.

Electrofishing catch rates were much lower in this reach when compared to upstream surveys. Other channel alterations and impoundments have occurred near the mouth. Near the mouth, the proportion of brown and rainbow trout to cutthroat trout increases. The stream is slow moving, sinuous and silted near the mouth.

Electrophoretic analysis of 25 cutthroat collected from Chamberlain Creek in November 1990 revealed a hybridized population (Leary, 1989).

\section{Clearwater River}

The Clearwater River drains sections of Missoula and Powell counties. The majority of the land area is administered by the Lolo National Forest, Clearwater state Forest, and large tracts 
of private commercial forest land. The clearwater River flows through a large glaciated valley, connecting a series of moraine lakes including: Clearwater, Rainy, Alva, Inez, Seeley, Salmon, Elbow and Blanchard Lakes. The lower reach, below Salmon Lake, occupies a channel entrenched in glacial till and glacial outwash before entering the Blackfoot River three miles south of

Clearwater Junction.

The Clearwater River enters the Blackfoot River at river mile 34.8. It's average annual discharge is 258 cfs (U.S.G.S., 1987). Primary land uses from the outlet of Salmon lake to the mouth include: recreation, timber harvest, livestock grazing, and wildlife management. Ingress is generally allowed on the private timberlands.

Fish populations were sampled in three sections from the mouth to the outlet of Salmon Lake. At the mouth of the Clearwater River a $450 \mathrm{ft}$. long section was sampled. We found rainbow dominated the fishery (Appendix Table 3). Nineteen rainbow and 1 brown trout were caught. The rainbow trout were mainly YOY (79\%). Overall habitat appeared good but only partially occupied.

Substrates in this section ranged from sands to large boulders with some silt. Immediately upstream from HWY 200 at the fishing access site, is a rainbow-brown trout co-dominated fishery. In a 200 ft. section, 6 brown trout, 7 rainbow trout and 1 whitefish were captured. Adults and juveniles were equally represented in the sample. Non-game fish present in the sample included: redside shiners and northern squawfish which were abundant; longnose suckers and dace which were common; and sculpins. Substrates ranged from sands to boulders with moderate amounts of silt. The riparian vegetation consisted of a cottonwood dominated overstory with a dogwood, alder understory and sedges and rushes as ground 


\section{CLEARWATER RIVER}

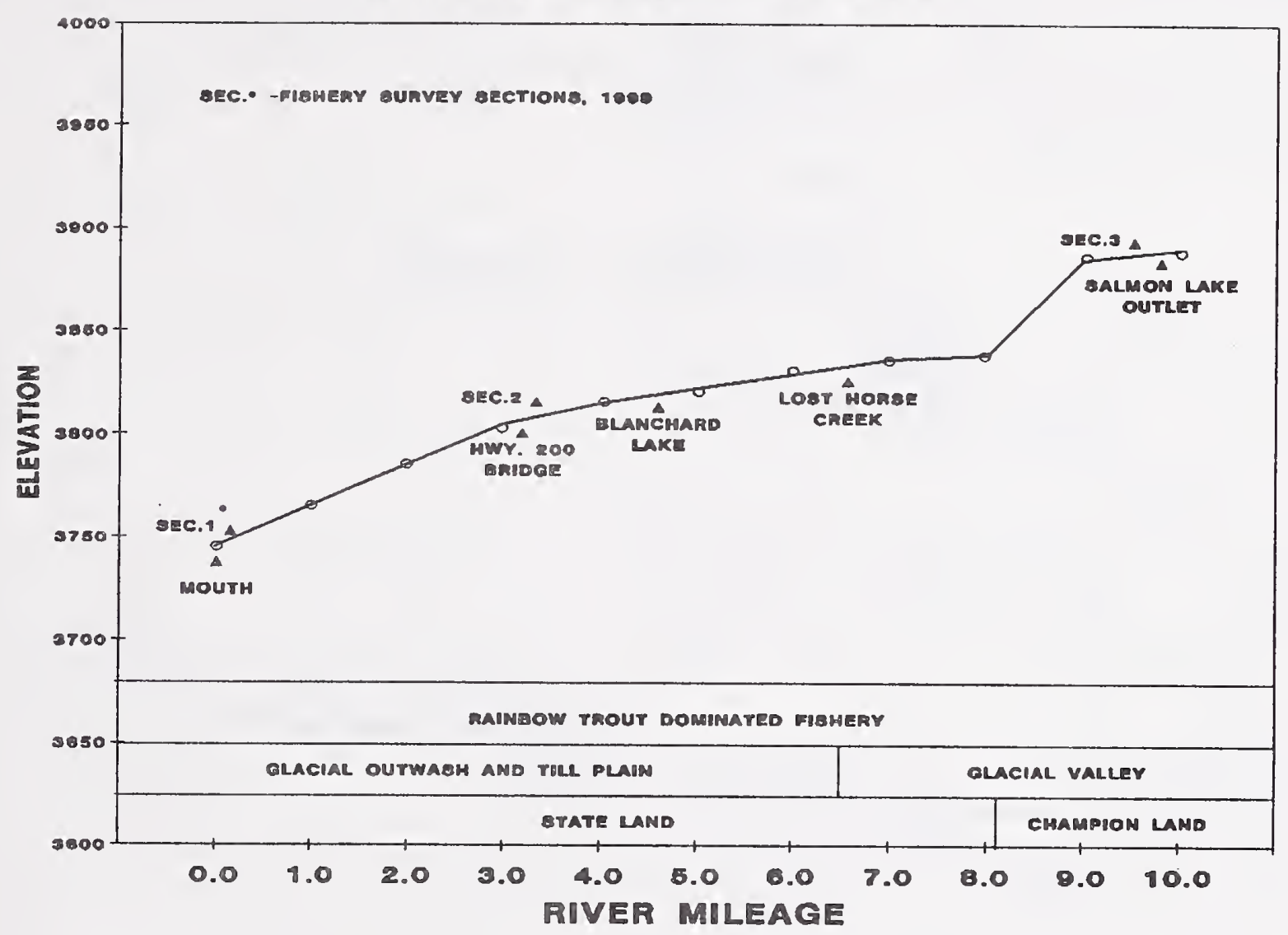

Figure 14. Stream channel gradient, land ownership, dominant trout species, stream flow characteristics, and fish sampling sections in the clearwater River.

At the outlet of Salmon Lake no fish were caught in a $200 \mathrm{ft}$ long sampling section. A large number of crayfish were observed. Substrates ranged from sand to cobbles with moderate to high levels of silt present.

The Clearwater River maintains an overall moderate gradient and a meandering course (Figure 14). A section of rapids is located immediately below Salmon Lake. The upstream lakes probably buffer discharge responses, reduce turbidity, and thermaliy regulate the stream. Surface water outlets on the lakes elevate water temperatures which may influence the density, distribution and composition of game fish found in the lower clearwater River. Water temperatures were not recorded but are expected to be in excess of optimum for salmonid fishes immediately below salmon Lake. 


\section{Copper Creek}

The Copper creek Basin, a third order stream and major tributary to the Lander's Fork, originates in the Red MountainIndian Meadows area, north of Lincoln, in Lewis and clark county.

Stream discharge of copper creek near the mouth was $35.5 \mathrm{cfs}$ on August 30, 1989. Thirty five cfs equals $37 \%$ of the flow in the Landers Fork, 4.1 miles above the confluence of the Blackfoot River.

\section{COPPER CREEK}

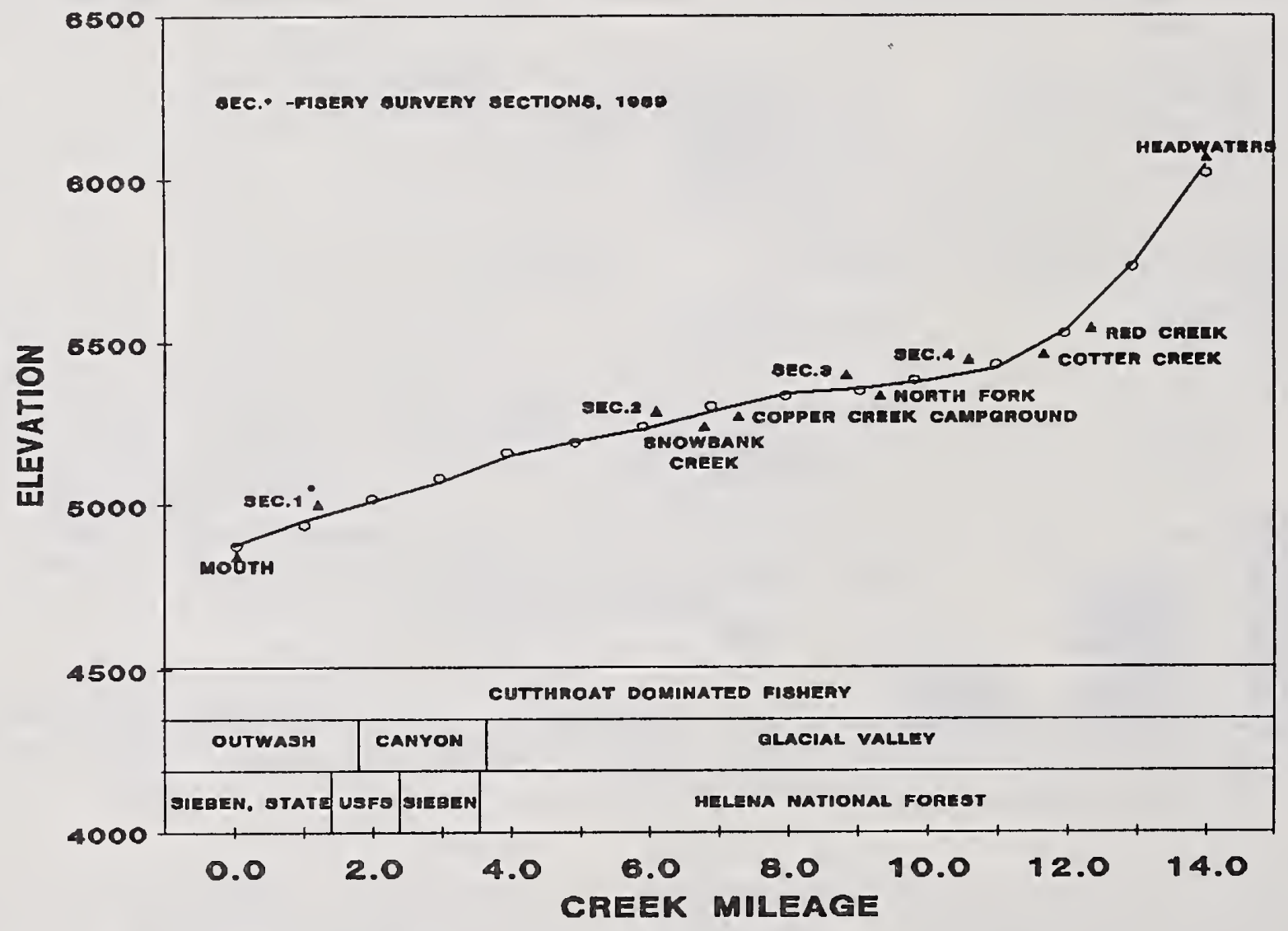

Figure 15. Stream channel gradient, land ownership, dominant trout species, stream flow characteristics, and fish sampling sections in copper creek.

Gradient of the channel is relatively constant from the mouth to stream mile 7.5 , averaging $60 \mathrm{ft} / \mathrm{mi}$ (Figure 15). Gradient decreases to $30 \mathrm{ft} / \mathrm{mi}$ from river mile 7.5 to about 11.0 or cotter creek area. From cotter creek upstream gradient averages $165 \mathrm{ft} / \mathrm{mi}$.

The basin is almost entirely Helena National Forest land except for a few private mining claims in the uppermost basin and two small sections of state and private lands in the lower basin. 
Basin land uses include mining, livestock grazing, timber, road construction, and recreational pursuits. A good gravel road parallels this stream over its entire course.

Copper creek flows easterly through a glacial trough in the upper reaches. The stream maintains a moderate velocity and a pool run sequence.

The trout habitat appeared good to excellent. Sampled sections had good amounts of woody debris, boulders, undercut banks and clean substrates. The

riparian area had been logged sporadically over its course.

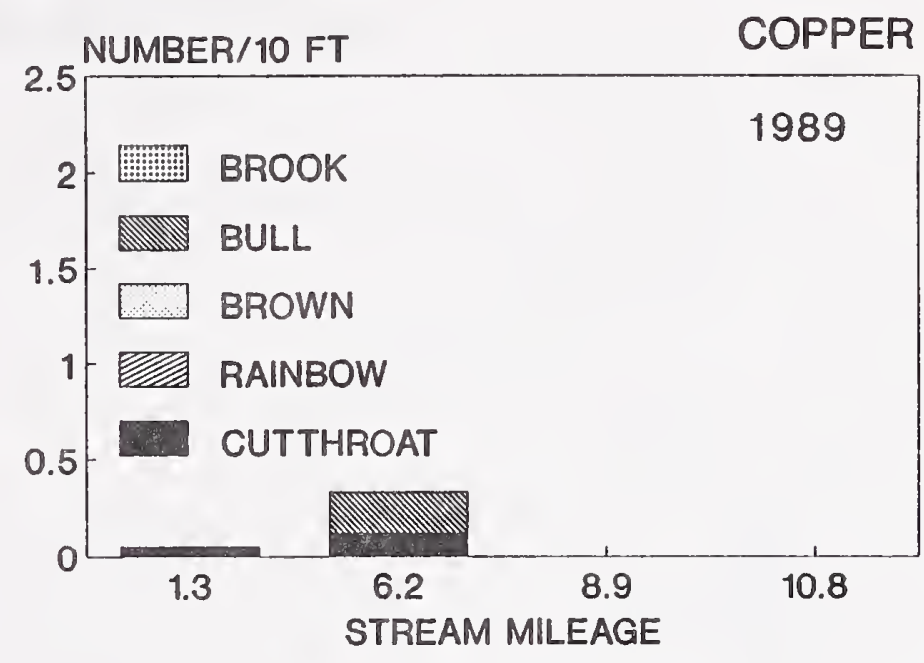

Fish populations were sampled in four sections of Copper Creek. Bull and cutthroat trout were the only species collected during our fish sampling. Low densities Figure 16. Density of young-ofthe-year trout per $10 \mathrm{ft}$. of stream length at sampled locations in copper creek in 1989 . of juvenile bull and cutthroat trout were found in the lower section about 0.5 mile above the mouth (Appendix Table 3). Below Snowbank lake, the habitat improves as did catch rates of cutthroat and bull trout. Most of the habitat appears only partially occupied in this section of stream.

Copper Creek YOY samples contained both cutthroat and bull trout (Appendix Table 2 and Figure 16). The densities of each were less than 0.30 YOY/10 ft. The greatest densities of YOY occurred at stream mile 6.2. No YOY were captured at stream mile 8.9 and 10.8. The densities of YOY bull trout were the second highest found in the Blackfoot drainage.

\section{Cottonwood Creek}

Cottonwood Creek is a 3 rd order stream entering the Big Blackfoot River at river mile 42.9. Cottonwood Creek originates at the outlet of cottonwood Lakes in the Morrell Mountain area of the Lolo National forest. Cottonwood Creek flows south for approximately 16 miles to its confluence with the Blackfoot River, about five miles east of Clearwater Junction. Stream discharge near the mouth was 35.1 cfs on september 27 , 1989 .

In upper reaches cottonwood creek flows within a wide glacially carved valley within an entrenched channel. Stream channel substrates range from cobbles to sand with some silt. At about stream mile 12.5 Cottonwood Creek enters an outwash 
zone, where it takes on a wide, shallow profile.

\section{COTTONWOOD CREEK}

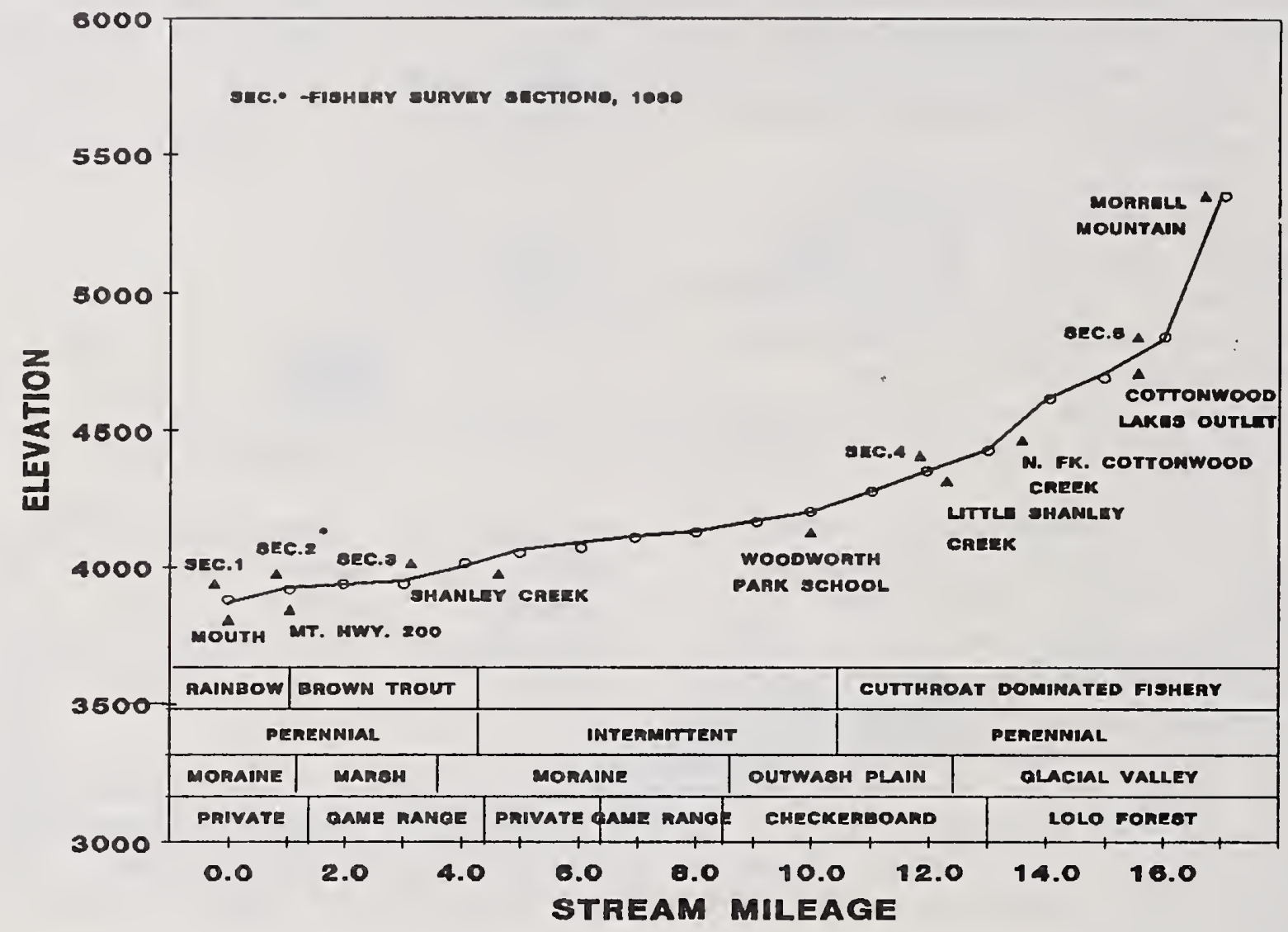

Figure 17. Stream channel gradient, land ownership, dominant trout species, stream flow characteristics, and fish sampling sections in cottonwood creek.

Gradient is moderate from the mouth to stream mile 13.0 averaging $40 \mathrm{ft} / \mathrm{mi}$ (Figure 17 ).

Cottonwood Creek is naturally intermittent, losing water to glacial outwash after leaving the mountains. Irrigation diversions also dewater portions of the channel as the flows decrease in the spring. Cottonwood creek resurfaces again in the lower reach at about stream mile 4.4. Beaver dams are common in the channel from the mouth to stream mile 3.0 .

In the lower reach (stream mile 0 to 1.2 ), the stream enters glacial till where it flows entrenched to its mouth. Substrates in this area consist of moderately small boulders to gravel. Velocity increases slightly near the mouth. Throughout the lower perennial section, the stream maintains excellent adult fish habitat with good riparian vegetation, undercut banks and a pool, riffle, pool sequence.

The overstory riparian vegetation in the upper reaches , 
GOLD CREEK

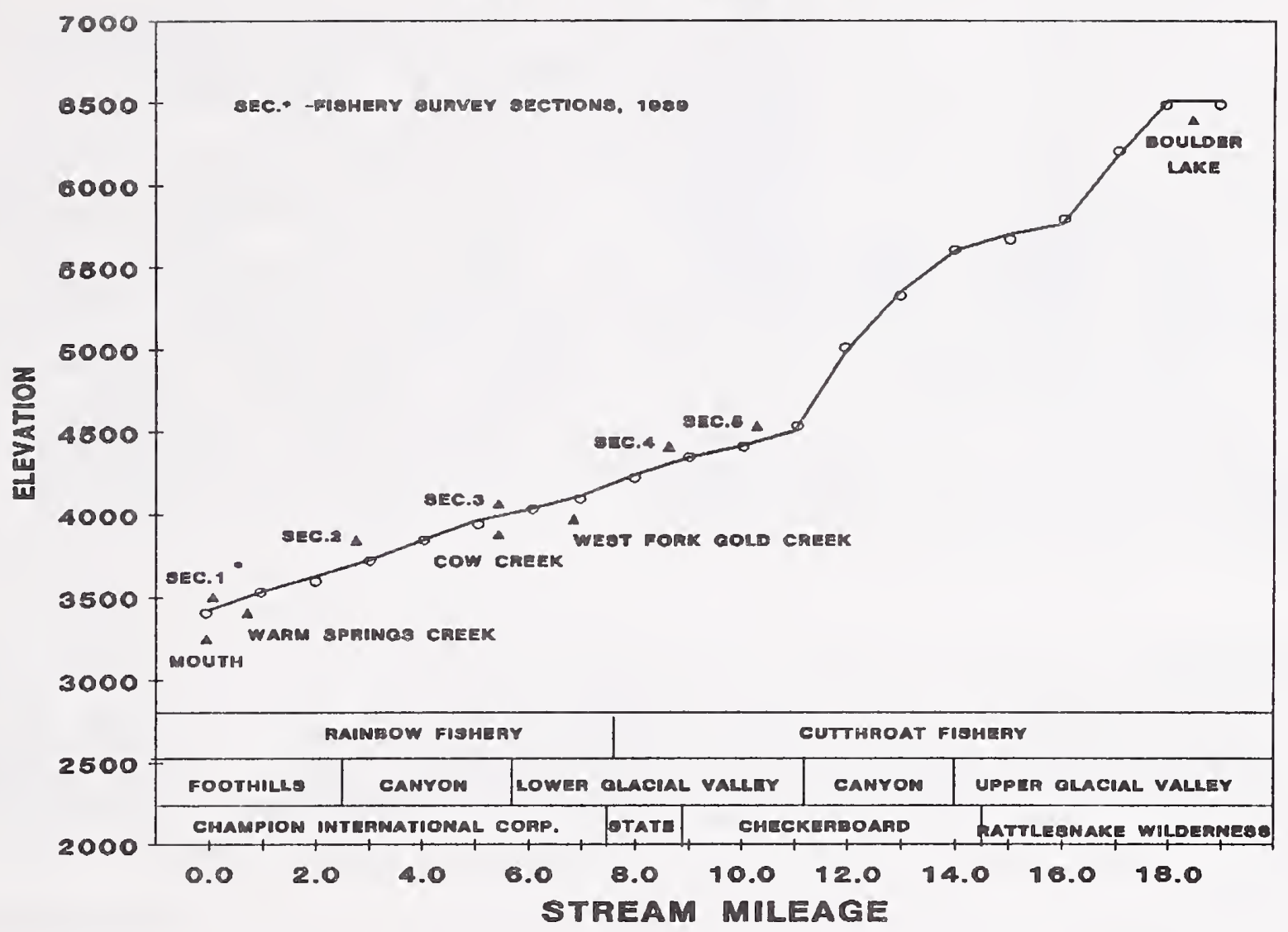

Figure 18. Stream channel gradient, land ownership, dominant trout species, stream flow characteristics, and fish sampling sections in Gold Creek.

stream mile 12 to 17 , consists of subalpine fir, spruce, cottonwood and an understory of red-osier dogwood, mountain maple, alder, and thimbleberry. In the middle reaches, stream mile 4 to 12 , the vegetation becomes a mixed woodland with spruce, ponderosa pine, cottonwood, willow and alder. overgrazing and trampled banks appear to have caused the loss of riparian vegetation and the stream to take on a wide shallow profile. In the perennial reach, willows

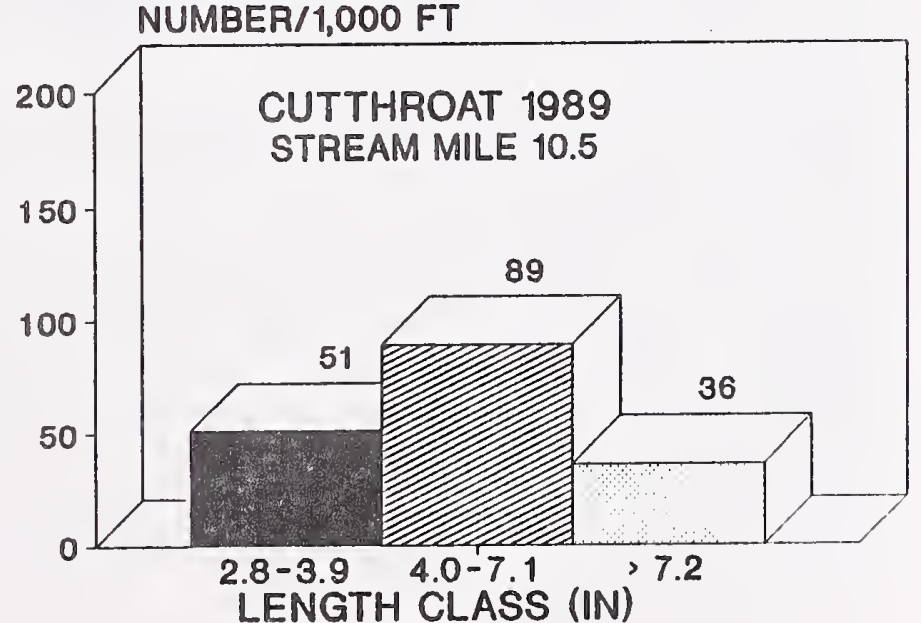

Figure 19. Estimated cutthroat trout population density in Gold creek at stream mile 10.5 in 1989. 
dominate the riparian vegetation. Near the mouth ponderosa pine, cottonwood, alder and willow dominate the overstory with sedges bordering the shoreline.

Basin land ownership is about equally divided between the private and public sectors with state and Federal agencies representing the public land; and Champion, Plum Creek, and individual owners representing the private land.

Fish sampling was completed on september 26 and 27, 1989, from the headwaters to the mouth. Cutthroat dominate the fishery in the upper reach (stream mile 12.4 and 15.9). Bull, brook and rainbow trout are also found in the reach in low densities

(Appendix Table 3). In the lower reach (stream mile 3.3 to 1.0), brown trout dominate the fishery with a population of $105 \pm 9$ fish larger than 3.1 in. TL per $1000 \mathrm{ft}$. (Appendix Table 4). Near the mouth, moderate numbers of rainbow YoY were captured (Appendix Table 2). The large fish habitats were occupied exclusively by large brown trout.

\section{Gold Creek}

Gold Creek, a 3 rd order stream, originates in the glacially scoured mountainous landscape below Boulder Peak. From Boulder Lake, Gold Creek flows southeast 18 miles through a glaciated valley. Gold Creek enters the Blackfoot River at river mile 13.5 . 1989.

Stream discharge was 24.3 cfs near the mouth on september 6 ,

The headwaters reach flows through the Rattlesnake

Recreation and Wilderness Area. Gold Creek then enters lands in a checkerboard pattern of ownership between USFS and Champion International commercial timber lands. Land uses range from wilderness recreational pursuits like hunting, fishing and backpacking to intensive timber harvest. The stream channel gradient averages $217 \mathrm{ft} / \mathrm{mi}$ from the headwaters to stream mile 10.8 (Figure 18).

In upper to middle reaches (stream mile 19 to 10 ) the riparian vegetation consists of a spruce dominated forest with alder, dogwood and rose in the undergrowth. The stream channel has a moderate amount of good pools. Substrates range from boulders to sand with moderate amounts of silt. Gold creek enters a V-shaped canyon at stream mile 5.7. In this area subalpine fir becomes the dominant overstory species. In some areas of the canyon, the stream flows over bedrock.

The riparian vegetation near the mouth consists of shrub dominated vegetation with alder, willow, dogwood, rose, and thimbleberry with sedges and rushes along the shoreline. Gold Creek is wide and shallow near the mouth with moderate gradient and velocity. Boulders are randomly scattered where the stream is entrenched in glacial deposits. Stream channel gradient averages $102 \mathrm{ft} / \mathrm{mi}$ from the mouth to stream mile 10.8 . 
Gold Creek sustains spawning migrations of bull, brown, rainbow and possibly cutthroat trout from the Blackfoot River. The estimated density of cutthroat trout larger than 7.2 in. TL at stream mile 10.5 was $38 / 1,000$ ft (Figure 19 and Appendix Table 4).

In Gold Creek we found YOY of five trout species: brook, bull, brown, cutthroat and rainbow. Near the mouth, catch rates of rainbow YOY were the highest of any tributary sampled during 1989 field season, 5.9 YOY/10 ft (Figure 20 and Appendix Table 2). A trout species

transition zone occurs between stream miles 3.0 and 5.7 from a rainbow dominated fishery to cutthroat. This species transition zone is obvious with YOY densities (Figure 20). Upstream at roughly mile 5-6, the fishery changes to a westslope cutthroat and brook trout dominated fishery (Appendix Table 4).

\section{Grantier creek}

Grantier creek is a small spring fed tributary to the Blackfoot River. It enters the upper Blackfoot River at mile 108, one mile south of Lincoln.

The perennial section of the spring creek is 1.2 miles in length. The stream originates on the Grantier ranch from a series of spring ponds.

We conducted a channel elevation survey on the lower 1.1 miles of stream below the springs. Physical characteristics of the stream channel break this stream into three distinct reaches.

The lower reach begins at the mouth and extends upstream to approximately the confluence of Poorman Creek. The stream drops 3.2 feet in three-tenths mile of stream $(10.4 \mathrm{ft} / \mathrm{mi})$. The stream flows through a marshy area created by beaver dams. Extensive historical beaver activity has resulted in the lack of development of a distinct stream channel. This slow moving, beaver dammed and silted section may impede fish movement into Poorman Creek from the Blackfoot River. However this condition is not a recent development but rather a long term natural condition.

The middle reach consists of a beaver impounded section as well. The beaver impoundments in the middle reach have created a large body of open water. The pond covers approximately 5 acres. The depth of the pond was not determined. Grantier Creek 
enters this area via a defined channel. The gradient from Poorman Creek to the upper portion of the pond is 3.5 feet for three-tenths of a mile $(11.6 \mathrm{ft} / \mathrm{mi})$. This impounded reach provides excellent waterfowl/wetland habitat.

The upper reach has free-flowing sections of stream and 3 ponds. The gradient increases in this section to 7.3 feet over its one-half mile length $(14.6 \mathrm{ft} / \mathrm{mi})$. The stream flows with a moderate velocity over moderate to heavily silted substrates comprised of sand to small cobbles. A few riparian shrubs and over-hanging banks occur along the shoreline and provide some security for trout. It appears that past livestock grazing and bank trampling has reduced the overall quality and quantity of habitat in this reach. Although cattle have not grazed the site for four years according to the land owner.

This stream is primarily a groundwater fed system. It therefore, lacks flushing flows, except below the mouth of poorman creek. Without channel maintenance via flushing flows, the cleansing and recovery of the middle and upper reaches may take considerable time if left to natural processes.

No fish population sampling was completed on Grantier creek, however large brown trout were observed in the deeper ponds and pools in the system. A few large adult trout were observed during our survey of Grantier creek.

\section{Landers Fork}

The Landers Fork is a 4 th order stream and major tributary to the upper Blackfoot. The Lander's Fork originates in the Scapegoat Wilderness Area, 17 miles north of Lincoln, in Lewis and Clark County.

The Lander's Fork flows in a southerly direction through a glacially carved valley. The stream exits the Lincoln-Scapegoat Wilderness area at mile 16 and the Helena National Forest 1.4 miles farther downstream. It then flows through outwash and moraine forming a braided channel. A mix of private and state land form a checkerboard type of ownership pattern in this lower reach. The Lander's Fork flows into the Blackfoot River at river mile 116.1 .

Stream discharge of the Lander's Fork near the mouth was 94.9 cfs on September 13, 1989.

Stream channel gradient is relatively consistent throughout the basin averaging $70 \mathrm{ft} / \mathrm{mi}$ (Figure 21).

Basin land uses include mining, livestock grazing, timber harvest, road construction, hunting and other recreational pursuits. Ingress is restricted only on the lower portion of the stream. Access is facilitated by a road system which roughly parallels the stream course from the Wilderness Area to the mouth.

Fish sampling was completed on three sections in 1989. Catch rates for all trout species was extremely low for all sections (Appendix Table 3). The first section at the mouth was 781 


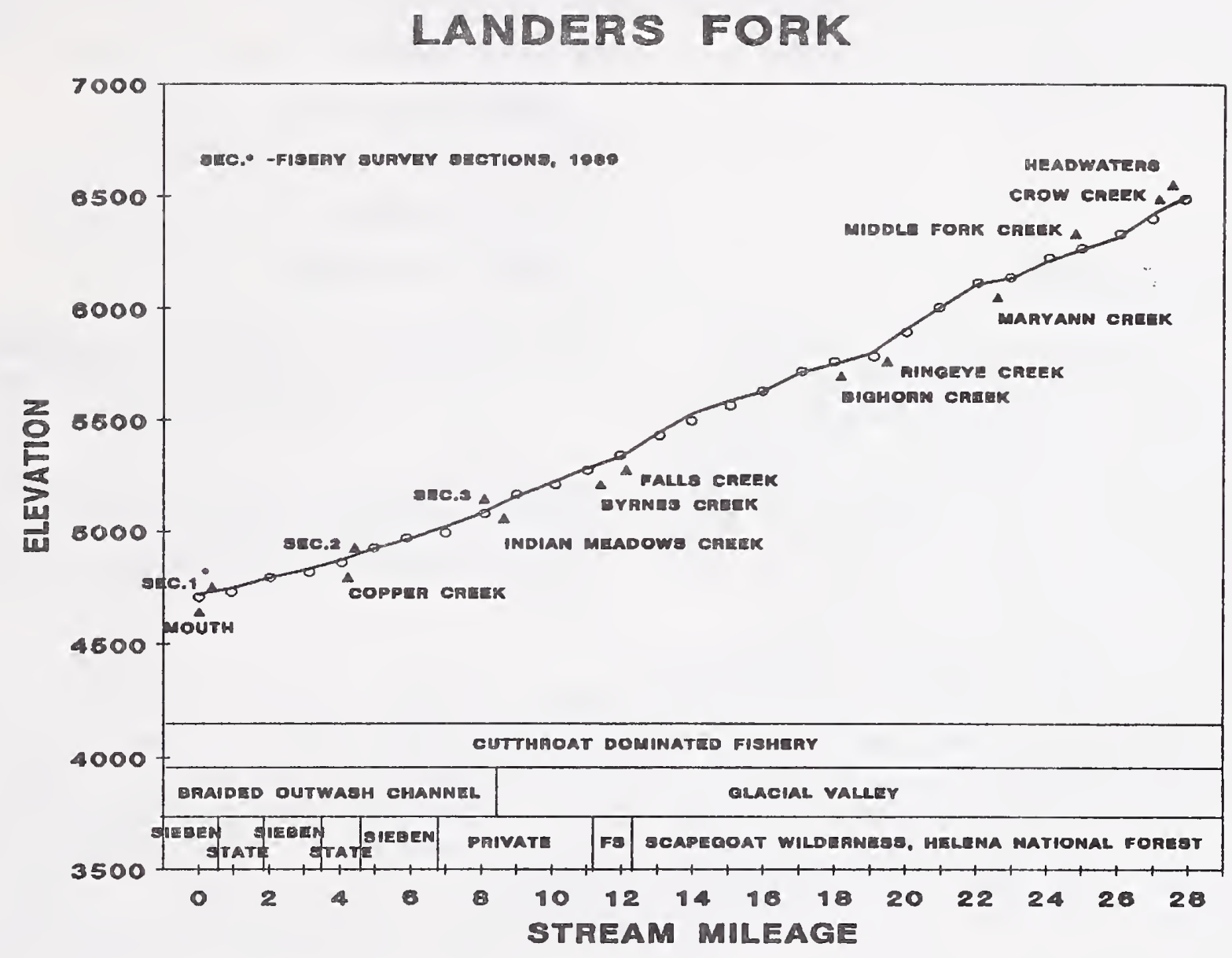

Figure 21. Stream channel gradient, land ownership, dominant trout species, stream flow characteristics, and fish sampling sections in the Lander's Fork.

ft.long. We captured juvenile mountain whitefish and cutthroat trout in very low densities. Sculpins were common. Substrates ranged from sand to cobbles. Much of the suitable habitat was vacant.

Section 2 at river mile 4.6 , was 410 ft. long and produced 1 yoY cutthroat trout (Figure 22 and Appendix Table 2). The stream was wide and shallow with a braided channel. Adult fish habitat was lacking. Substrates ranged from cobbles to sand with very little organic debris.

In section 3 , mile 8.2 , only 11 cutthroat trout were captured in a 490 foot section. The habitat was good but much of it was unoccupied. Sculpins were present. Substrates ranged from bedrock and large boulders to sands with some woody debris. The habitat was good for juvenile and adult fish. YoY samples contained only cutthroat trout in low densities, averaging only 0.02 YOY/10 ft.

All sections had relatively large amounts of ash present, 
which are originating from the Canyon Creek forest fire. The ash is depositing in the crevasses between stream bottom cobbles and shoreline areas.

\section{Monture Creek}

Monture creek, a 4 thorder stream, begins at the southern end of the Swan Range in Powell county. It borders the southern boundary of the Bob Marshall Wilderness. From the Middle Fork, Monture Creek flows south for 26 miles through lands owned by the YOUNG-OF-THE-YEAR

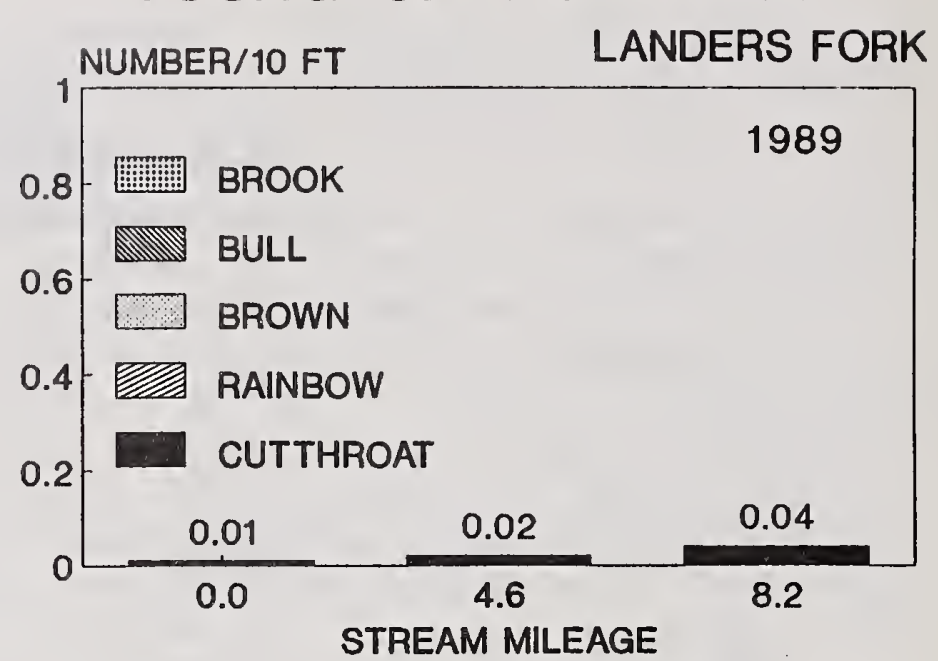

Lolo National Forest, Champion

International and private ranch operations.

Monture Creek enters the Blackfoot River at river mile 44.2 . Stream discharge was 88 cfs near the mouth on August 9, 1989.

Gradient in the headwater area averages $175 \mathrm{ft} / \mathrm{mi}$ (Figure

23). At approximately stream mile 20, Monture creek drops into a $V$-shaped incised canyon with a gradient of $320 \mathrm{ft} / \mathrm{mi}$. The lower reaches flow through gently to moderately sloping and undulating glacial till or outwash. Stream channel gradient in this lower reach averages $10 \mathrm{ft} / \mathrm{mi}$.

The channel forms a tightly meandering pattern once the stream exits the mountains. Gradient increases slightly above the mouth to about 20 feet per mile. Substrates ranged from gravel to boulders. Gravels and small cobbles were the predominant substrates with moderate to heavy amounts of silt. The stream seems to carry naturally high amounts of bedload. A large amount of woody debris and deep pools provide high quality pools and excellent habitat in most reaches.

The riparian vegetation ranges from a spruce, alder and willow dominated mixed woodland in upper reaches to a deciduous woodland dominated by cottonwood, alder, chokecherry and willow near the mouth. Some riparian areas have been cleared, overgrazed, or trampled by livestock.

Ingress is unrestricted in the National Forest portion of the basin. The forest service road ends at stream mile 14. Pack and hiking trails provide access to the upper basin and most major tributaries. In the privately owned lower section access is restricted.

Basin land-use practices include recreational pursuits (hunting, fishing, hiking and camping), trapping, commercial outfitting, timber harvest, hay and livestock production.

Rainbow and eastern brook trout were planted in Monture 


\section{MONTURE CREEK}

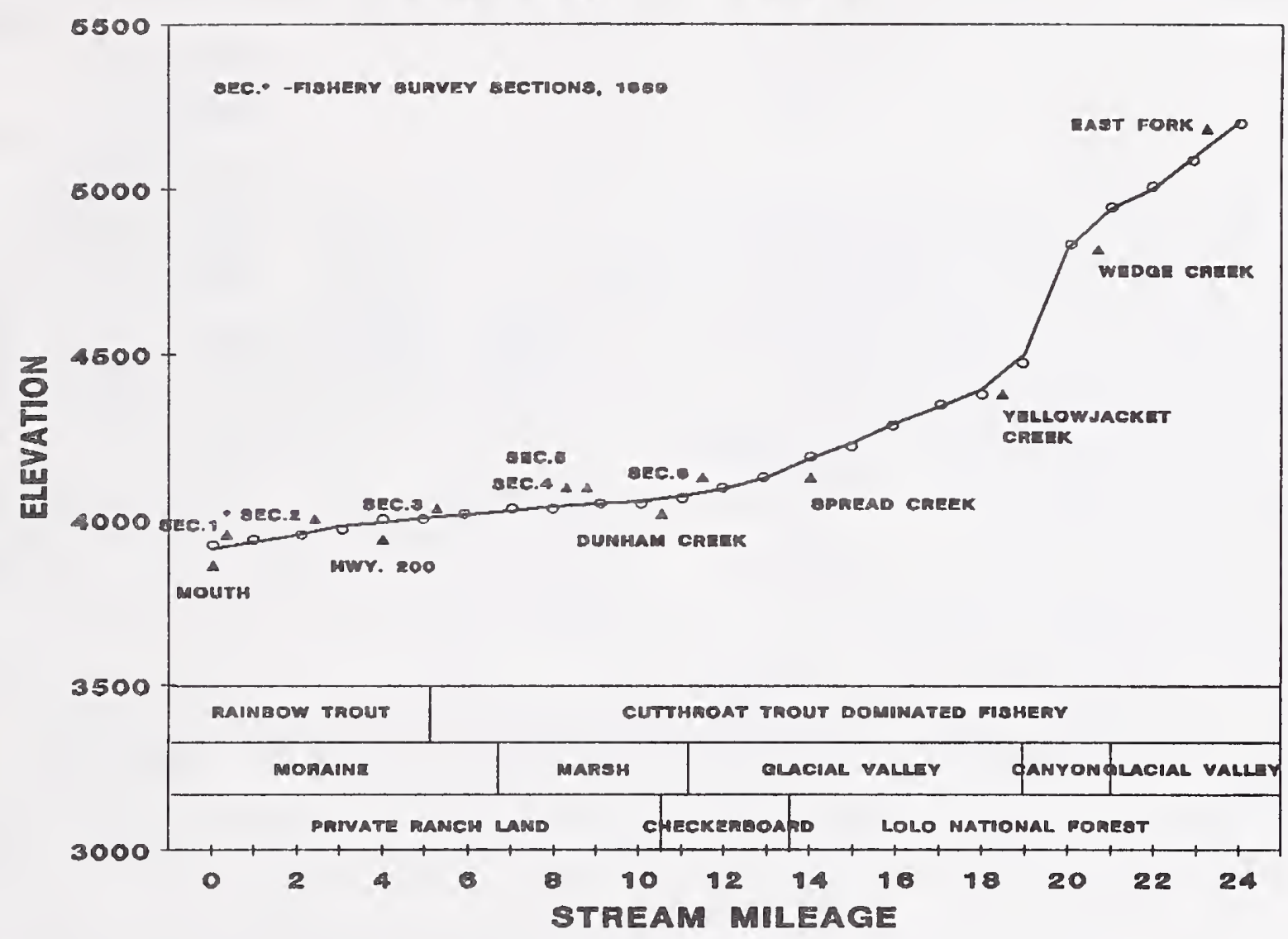

Figure 23. Stream channel gradient, land ownership, dominant trout species, stream flow characteristics, and fish sampling sections in Monture creek.

Creek irregularly between 1928 and 1969.

Fish sampling was completed in August, 1989. Six sections were sampled from the national forest boundary to the mouth.

The uppermost section at stream mile 12.9 was 620 foot long. Sampling produced low numbers juvenile fish and very few adult fish (Appendix Table 3). Twenty two eastern brook, thirteen westslope cutthroat and six bull trout were captured. This section has good pool development, gravelly substrates and fair amounts of woody debris incorporated into the channel. Most of the habitat is empty. About one-third to one-quarter of the shoreline area appears to be good rearing habitat.

In the swampy low gradient reach, stream mile 9, two sections, totaling 680 feet, were sampled. Only 26 fish were collected (Appendix Table 3 ). All trout species (cutthroat, bull and brook trout) were collected in equal numbers. This slow moving reach has moderate to heavy siltation and gravelly substrates. Trout rearing habitat was limited in this reach. 
At stream mile 5.5, a 545 ft. long sampling section, produced only 20 juvenile fish. Six each of brown and brook trout were collected with four cutthroat, 2 bull, and 2 rainbow.

A trout species transition zone occurs between stream mile 5.5 and 2.2. Rainbow and brown trout dominating below stream mile 5. cutthroat and brook trout dominating the stream above stream mile 5 .

At stream mile 2 (MTDFW\&P fishing access site), YOY sampling in the $330 \mathrm{ft}$ long section produced 38 juvenile fish (Appendix Table 2).

Fourteen rainbow trout were collected followed by 13 brown trout, 7 eastern brook, 2 bull trout and 2 cutthroat. About onethird of the shoreline section appeared to be good rearing habitat.

Catch rates for both adult and juvenile trout seemed low for the available habitat in all six sampled sections.

On November 10, 1989, a bull trout redd count was completed from mile 8 to mile 13. Eight redds were observed from mile 11 to 13. Two other possible redds were observed in the complete surveyed section that was 5 miles long.

\section{Nevada Spring Creek}

Nevada spring creek is an artesian spring and ground water fed stream. It is a major tributary to Nevada Creek. This low slow moving, tightly meandering stream flows west 3.4 stream miles through farm/ranch lands. Nevada Spring Creek enters Nevada Creek at river mile 6.4 The mean gradient is $3.6 \mathrm{ft} / \mathrm{mi}$. This spring creek originates $1 / 4$ mile west of U.S. 12 and four miles North of Helmville from glacial till, outwash, and alluvial stream deposits. The wide sinuous spring creek flows though a flat alluvial plain.

Discharge measured at the spring source was $10.4 \mathrm{cfs}$ on November 2, 1989 (Appendix Table 5). Additional inflows of water were evident within the first $0.5 \mathrm{mi}$. reach from the spring source. Nevada spring creek flows entirely within private ownership. Ingress is restricted. Water uses include irrigation and stock water.

The woody riparian vegetation has been removed in the upper end by season-long grazing practices. Near the mouth bank vegetation includes dogwood, willow, rush and sedges with juniper 
and sagebrush as upland vegetation. The riparian vegetation at the mouth has been severely damaged by livestock in places. Creek.

No fish sampling was completed in 1989 on Nevada Spring

\section{Nevada Creek}

Nevada creek is a major tributary to the Blackfoot River. stream flow near the mouth is maintained primarily from Nevada Spring creek in the low flow period. Nevada Creek below Nevada creek Reservoir is used primarily for irrigation and stock water. It's primary tributaries are McElwain Creek, Douglas Creek and Nevada Creek. Nevada Creek enters the Blackfoot River at stream mile 67.8. Stream discharge of Nevada Creek was 43.8 cfs on November 2,1989 near the mouth. That amount equals 39.7 percent of the Blackfoot River discharge at the mouth of Nevada creek.

Fish sampling was completed November 2, 1989. Seven species of fish were found in a 650 foot section near the mouth (Appendix Table 3). Most of the suitable habitat appeared vacant.

No adult brown trout were captured nor were any redds observed during fall surveys. Stream bottom substrates in Nevada Creek near the mouth were heavily silted with some boulders, rubble and gravel.

\section{North Fork of the Blackfoot River}

The North Fork of the Blackfoot River, is a 4 th order stream and is the largest tributary to the Blackfoot River. The North Fork drains the western slopes of the Continental Divide in the Scapegoat Wilderness Area, in Lewis and Clark, and Powell counties.

From Dobrota Creek, the North Fork flows southwest 34.6 miles before entering the Blackfoot River at river mile 54.1. Discharge was 300 cfs near the mouth on August 16, 1989.

The stream channel gradient is relatively uniform from the mouth to river mile 25 averaging $50 \mathrm{ft} / \mathrm{mi}$ (Figure 25).

In the mountainous upper reach, the stream channel is entrenched in glacial till within a glacially carved valley. At river mile 14, the stream exits the mountains and enters Kleinschmidt Flats, a glacial outwash and till plain. It flows along the northern boundary of the outwash before again entering glacial moraine at mile 6. From river mile 6 it remains entrenched in moraine to its confluence with the Blackfoot River.

The mountainous reach flows through large glacially deposited boulders. As it enters the Kleinschmidt outwash, the stream becomes wide and shallow with good pool and riffle development. About two miles into the outwash plain at river 
mile 12, the North Fork loses water to the outwash gravels and becomes intermittent. It gains water again at about mile 9 and remains perennial to its mouth. Below mile 9 the stream provides excellent fish habitat.

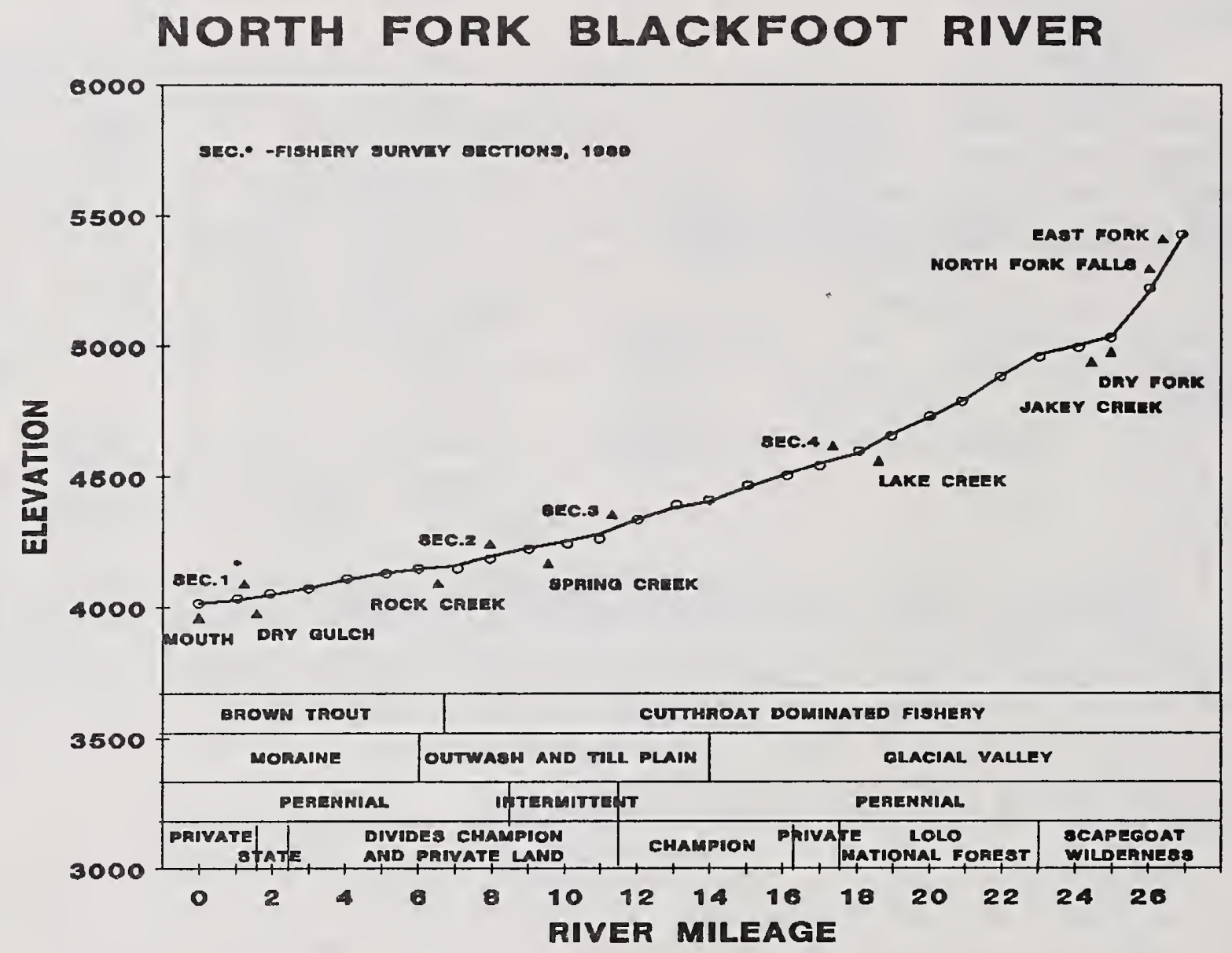

Figure 25. Stream channel gradient, land ownership, dominant trout species, stream flow characteristics, and fish sampling sections in the North Fork of the Blackfoot River.

The North Fork ran dark grey in color several times in 1989. Intense rain showers washed ash and silt into the channel from bare mountain slopes created by the Canyon Creek Fire of 1988 .

Four sections were sampled for juvenile fish in Yoy rearing habitat in August 1989 downstream from river mile 17 (Figure 26). The densities of fish were very low in upper sections, increasing slightly downstream (Appendix Tables 2 and 4 ).

At river mile $2.6,39 \mathrm{fish}$ were caught in a $590 \mathrm{ft}$. section. Fifty-four percent of the total catch were yoY. Twenty nine percent were brown and $71 \%$ were rainbow trout. All cutthroat captured were hatchery fish.

A population estimate was completed on a section of the North Fork from HWY 200 (river mile 6.2) to the Harry Morgan 
fishing access, 3.9 miles in length. This section was established as a long term monitoring section. Brown trout dominate this fishery (Figure 27 and Table 7). The section held an estimated 4.3 brown trout larger than 12 in. TL per 1,000 ft of stream length. Other trout species present included: rainbow, cutthroat, bull, and eastern brook trout. Estimated bull, cutthroat, and rainbow densities were less than 6.4/1,000 ft. The total density of trout larger than 5.0 in. TL for this section was $19.6 / 1000 \mathrm{ft}$. The fish habitat in this section was excellent, and appears only partially occupied.

Table VII. Mark and recapture population estimates for the North Fork of the Blackfoot River, completed in September, 1989.

\begin{tabular}{|c|c|c|c|c|c|c|c|}
\hline $\begin{array}{l}\text { Location } \\
\text { (river mile) }\end{array}$ & $\begin{array}{l}\text { Section } \\
\text { length } \\
\text { (mi) }\end{array}$ & Specie & $\begin{array}{l}\text { Size class } \\
\text { (in) }\end{array}$ & $\begin{array}{l}\text { Marked } \\
\text { (M) }\end{array}$ & $\begin{array}{l}\text { Captured } \\
\text { (C) }\end{array}$ & $\begin{array}{l}\text { Recaptured } \\
\text { (R) }\end{array}$ & $\begin{array}{l}\text { Estimated } / 1,000 \mathrm{ft} \\
\text { (95\% C.I.) }\end{array}$ \\
\hline \multirow{5}{*}{$\begin{array}{l}\text { North Fork } \\
\text { Blackfoot River } \\
(4.0)\end{array}$} & 3.9 & $\begin{array}{l}\text { Rainbow } \\
\text { trout }\end{array}$ & $\begin{array}{c}(6.0-11.9) \\
\geq 12.0\end{array}$ & $\begin{array}{r}17 \\
7\end{array}$ & $\begin{array}{r}12 \\
4\end{array}$ & $\begin{array}{l}2 \\
1\end{array}$ & $\begin{array}{l}3.7 \pm 3.0 \\
0.9 \pm 0.8\end{array}$ \\
\hline & & $\begin{array}{l}\text { Brown } \\
\text { trout }\end{array}$ & $\begin{array}{l}(6.0-11.9) \\
\geq 12.0\end{array}$ & $\begin{array}{l}26 \\
33\end{array}$ & $\begin{array}{l}36 \\
20\end{array}$ & $\begin{array}{l}5 \\
7\end{array}$ & $\begin{array}{l}8.1 \pm 4.8 \\
4.3 \pm 1.9\end{array}$ \\
\hline & & $\begin{array}{l}\text { Bull } \\
\text { trout }\end{array}$ & $\begin{array}{c}(6.0-11.9) \\
\geq 12.0\end{array}$ & $\begin{array}{l}5 \\
9\end{array}$ & $\begin{array}{r}3 \\
10\end{array}$ & $\begin{array}{l}0 \\
5\end{array}$ & $0 . \overline{8} \pm \overline{0} .3$ \\
\hline & & $\begin{array}{l}\text { Cutthroat } \\
\text { trout }\end{array}$ & $\geq 8.0$ & 8 & 6 & 2 & $1.0 \pm 0.5$ \\
\hline & & $\begin{array}{l}\text { Brook } \\
\text { trout }\end{array}$ & $\geq 5.0$ & 11 & 2 & Total & $\begin{array}{c}0.8 \pm 0.4 \\
19.6 \pm 11.8\end{array}$ \\
\hline
\end{tabular}

At river mile 7.9 , bull trout were dominant (Appendix Table 3). Mountain whitefish, rainbow trout, cutthroat, and brown trout were also present. Six bull trout YOY were observed.

At river mile 11.5, bull trout dominated our catch. cutthroat trout, brown trout, and mountain whitefish were also captured. Sculpins were abundant in this section. The rearing habitat was fair, but still only partially occupied.

At river mile 17.2 , only 6 fish were caught in a $323 \mathrm{ft}$. long section; five were bull trout and one was a rainbow trout. sculpins were also abundant in this section.

Brown and rainbow trout YOY were only found at river mile 2.6 (Figure 26). Bull trout dominated our yoY samples at river mile 7.9, 11.5, and 17.2. Some cutthroat YOY were captured at river mile 11.5 and 17.2 . in extremely low densities. The highest densities of bull trout found in the Blackfoot drainage, $0.33 / 10$ ft were in the North Fork at river mile 7.9 .

\section{Poorman Creek}


Poorman Creek originates along the Continental Divide and flows northwest for about 15 miles before entering the Blackfoot River.

The stream channel gradient increases from $95 \mathrm{ft} / \mathrm{mi}$ near the mouth to $370 \mathrm{ft} / \mathrm{mi}$ at stream mile 13 (Figure 28).

The lower end of Poorman creek is privately owned. Much of the upper basin is public land and most of the valley floor is private land and is currently being developed for homes. An improved dirt road leading south from Lincoln accesses the stream from mile 3 to mile 13.2.

Agriculture, channelization and mining operations (dredging) affect water quality and \or quantity and the overall habitat rating of this stream. From the mouth to mile three, the stream is intermittent, losing water to alluvium and

irrigation. Mining activity begins approximately at stream mile 8.0. and appears

sporadically throughout the upper basin.

In upper reaches, cottonwood, aspen, willow, shrubs and rushes make up the riparian vegetation. The

YOUNG-OF-THE-YEAR

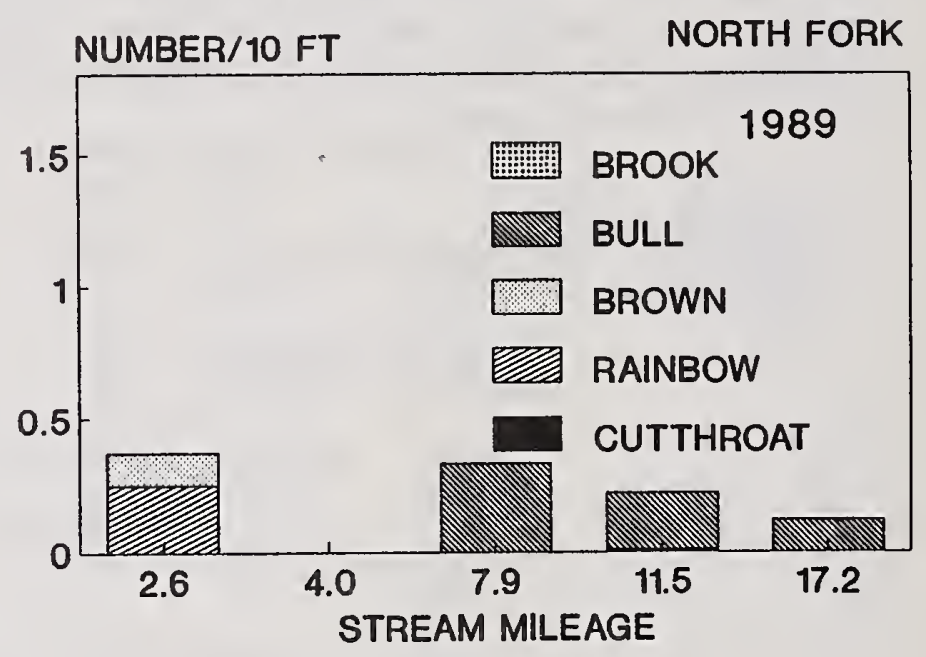

Figure 26. Young-of-the-year trout densities at sampled locations in the North Fork of the Blackfoot River, 1989.

riparian vegetation changes to a narrow strip of mature cottonwoods upon leaving the mountainous reach on to agricultural lands.

The upper stream valley appears to have been glacially scoured. The lower stream reach flows through glacial deposits. Stream bottom substrates range from gravels to boulders in the upper reaches, and gravelly in the lower reaches. Low to moderate amounts of silt are present throughout the system. In middle reaches, the habitat is above average for trout residence and excellent for spawning and rearing.

Hatchery rainbow and cutthroat trout, of unknown genetic origin, were planted in the $1920^{\prime} \mathrm{s}$ until 1952. Although contaminants were planted, pure westslope cutthroat inhabit the stream according to Leary, 1989. Some bull trout captured appeared to be bull/brook hybrids.

Fish populations were sampled in two sections of Poorman creek in september, 1989 (Appendix Table 3). The upper most section at stream mile 9.9 had cutthroat, bull and brook trout. Cutthroat were most abundant with 34 fish collected, followed by bull trout with 11 , and 7 brook trout in the 340 foot long 
section.

At stream mile 4.5, cutthroat, brook, brown and bull trout were caught (Appendix Table 4). A good population of small cutthroat (3.1 - 11.1 in. TI) occupied this reach with a density of 248/1,000 ft. Compared to the upper section, the lower section has better pool

development and adult habitat. In addition, the lower section supports higher densities of YOY (Appendix Table 2).

\section{Rock Creek}

Rock Creek originates in
NORTH FORK OF THE BLACKFOOT HWY 200 TO HARRY MORGAN

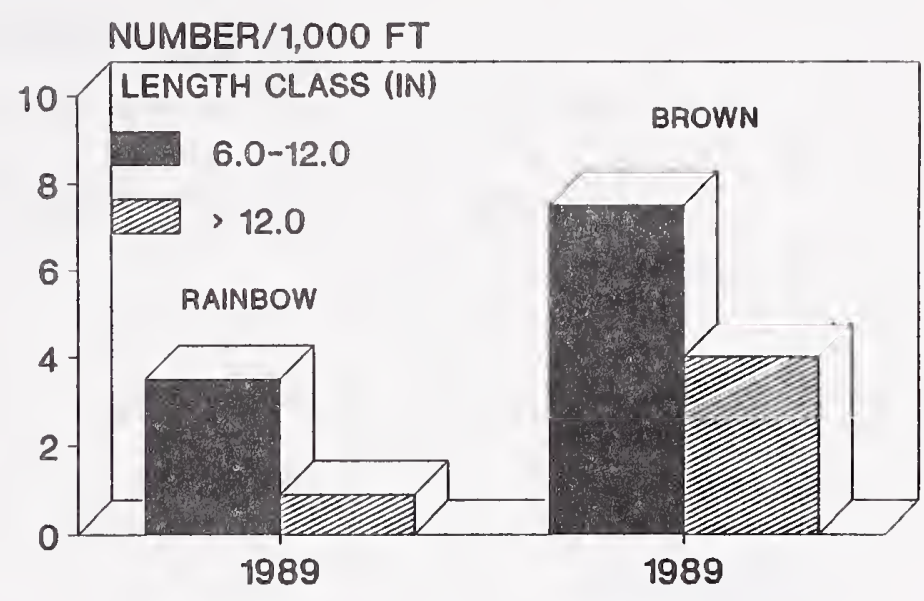

Figure 27. Estimated population density for selected size classes of rainbow and brown trout in the North Fork of the Blackfoot River, August, 1989.

Powell county. From its

confluence with Dry Creek, Rock Creek flows southwest for nine miles to its confluence with the North Fork of the Blackfoot River at river mile 6.2.

At stream mile 8 , Rock Creek leaves the forested mountains and enters Kleinschmidt Flat, a large glacial outwash and till plain. Rock Creek loses water to the outwash plain and becomes intermittent from stream mile 7.5 to 3.0 . Water resurfaces in a lower outwash channel where it becomes perennial. This section of the creek is bordered entirely by private land. The primary use is for livestock forage production.

The stream channel gradient of Rock Creek is uniform in the outwash plain area, averaging $30 \mathrm{ft} / \mathrm{mi}$ (Figure 29).

Stream discharge of Rock Creek near the mouth was 53 cfs on July 24, 1989. The Rock Creek channel profile is wide and shallow, and has a moderate gradient of 30 feet per mile in the perennial lower reach. Substrates range from large boulders to gravel with moderate to heavy amounts of silt present.

Brook, rainbow and brown trout were collected in July, 1989 (Appendix Table 3) during electrofishing surveys. Brown and rainbow trout YOY and older juvenile fish dominated the catch at stream mile 0.3 (Appendix Tables 2 and 3 ). Brook trout YoY were present, but catch rates were low. Few adult trout were captured.

Upstream near a diversion at stream mile 1.2 , catch rates decreased for juvenile fish and increased for adult brook and brown trout. Upstream near stream mile 3, the stream becomes wide and shallow, flowing between large glacially deposited boulders. Habitat quality is poor because riparian shrubs have been eliminated. Brook trout inhabit this section almost exclusively; only one YOY brown trout was captured. Willow, 


\section{POORMAN CREEK}

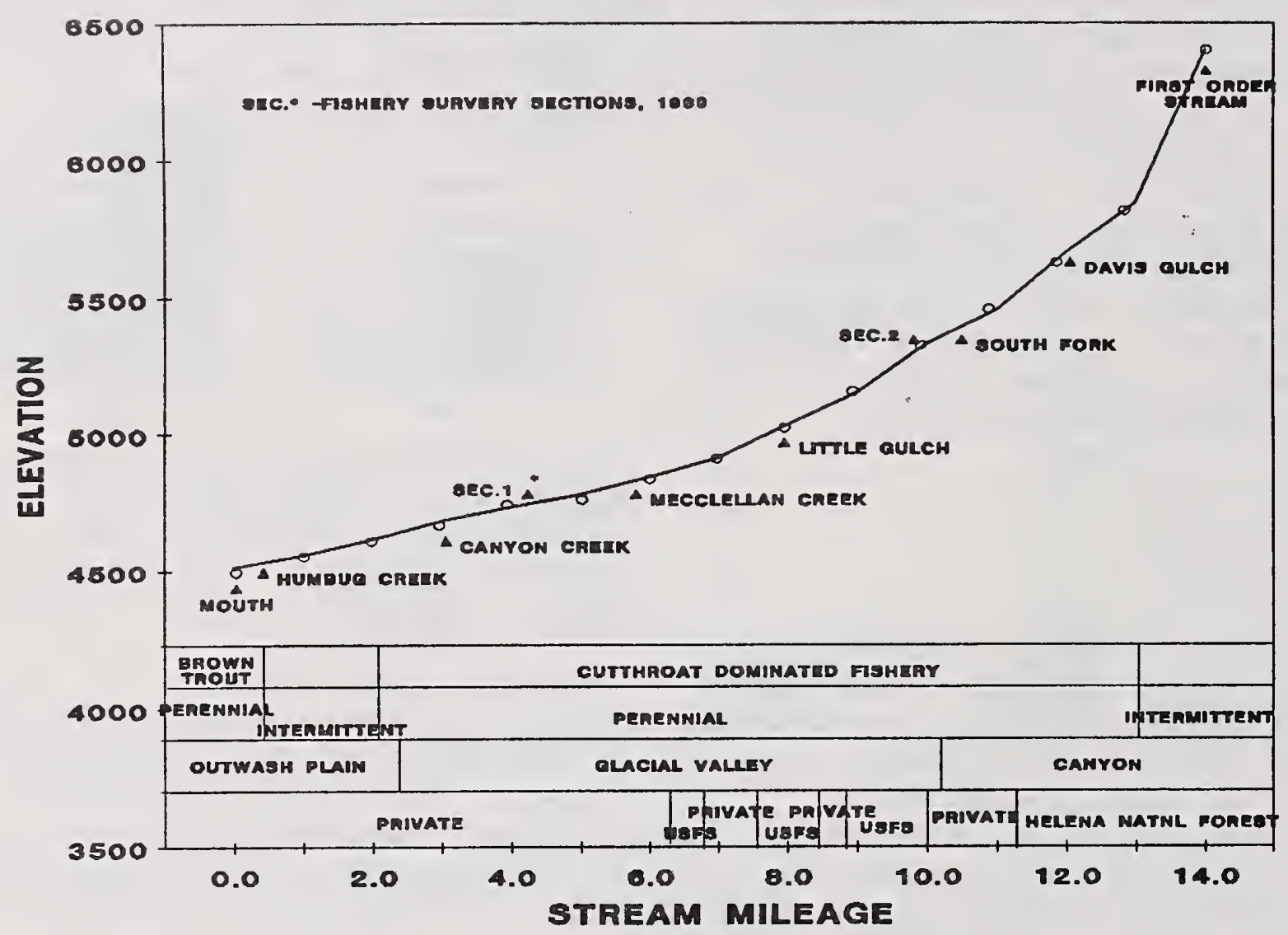

Figure 28. Stream channel gradient, land ownership, dominant trout species, stream flow characteristics, and fish sampling sections in Poorman creek.

ponderosa pine, spruce, and undercut banks provide limited cover and some habitat for adult fish in the lower reach. Sedges and grasses along shoreline areas provide some rearing habitat.

The culvert under highway 200 , as well as, a series of upstream culverts may limit upstream migrations of spawning fish due to high velocities through these constrictions.

On November 22, 1989, 15 suspected brown trout redds were counted from the mouth of Rock creek to stream mile 1.2 above the diversion for the trout raceways. In Klienschmidt (Ginoff) Creek, a tributary of Rock creek, 7 redds were found in the lower $1 / 3$ mile of channel.

\section{Union Creek}

Union creek is a 3 rd order stream, which drains the Garnet Mountain Range in Missoula County. The stream flows northwest 
ROCK CREEK

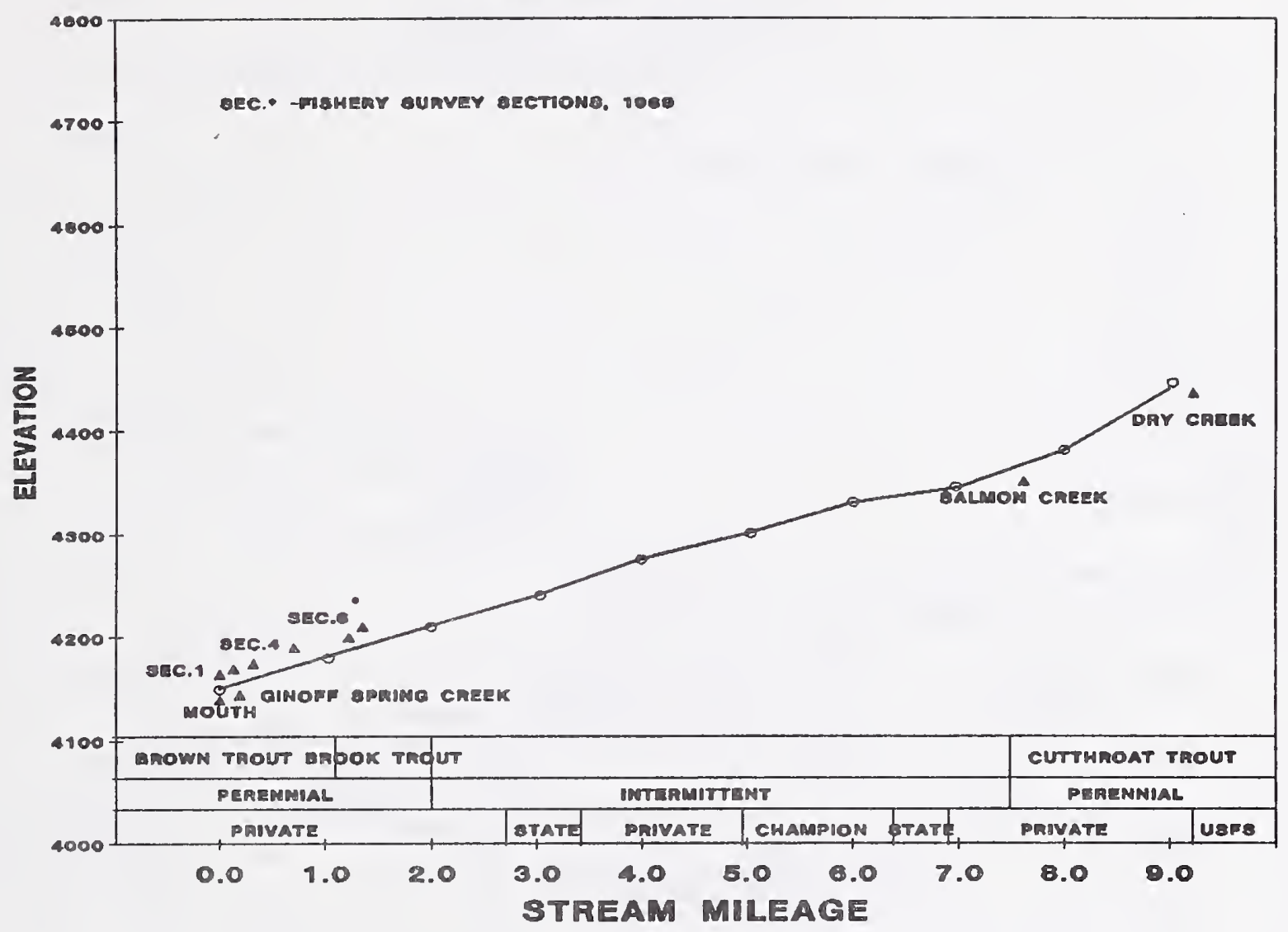

Figure 29. Stream channel gradient, land ownership, dominant trout species, stream flow characteristics, and fish sampling sections in Rock Creek.

about 20 miles before entering the lower Blackfoot River at river mile 12.9 just above McNamara Bridge. Discharge of Union Creek was 6.4 cfs near the mouth on November $17,1989$.

The stream drains mineralized Belt rock mountains in the upper reaches and flows through volcanic ash and lake deposits that blanket the foothills and the Potomac Valley.

The basin consists of primarily state owned and private lands. The headwaters drain the Lubrecht Experimental Forest, the Clearwater state Forest and Champion International timber lands. The mid and lower reaches flow through the camus Prairie and the agricultural lands it supports.

The forested upper reaches maintain a moderate gradient and flow within an incised forested canyon (Figure 30). At stream mile 15, Union Creek enters the gently sloping agricultural land. At mile 9, the stream enters Camus Prairie. In the Camus Prairie the stream channel is tightly meandered with low gradient. The stream channel gradient averages $20 \mathrm{ft} / \mathrm{mi}$. through this area. 
Stream gradient increases near the mouth, becoming turbulent and bouldery before entering the Blackfoot River.

\section{UNION CREEK}

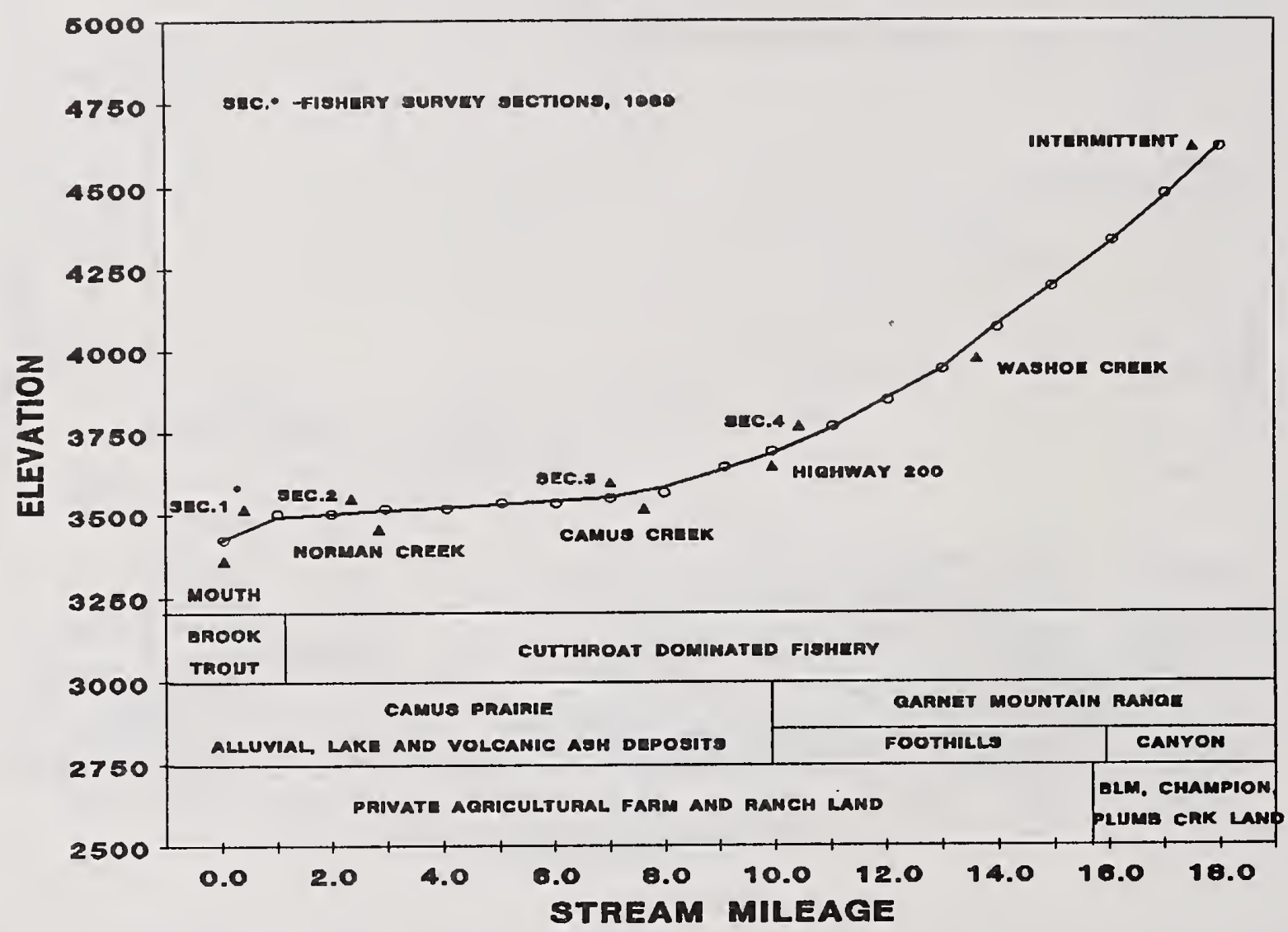

Figure 30. Stream channel gradient, land ownership, dominant trout species, stream flow characteristics, and fish sampling sections in Union Creek.

Fish populations were sampled in four stream reaches in the mid to lower reaches of Union Creek. The stream supports mostly rough fish and a poor trout fishery (Appendix Table 3 ).

At mile 10, our sampling produced mostly longnose suckers and redside shiners and only one cutthroat. Downstream at mile 7 , catch rates of cutthroat increased with suckers and shiners becoming abundant. One eastern brook trout was also captured. At stream mile 2.5 no trout were captured. Longnose suckers were common and redside shiners were abundant. In the turbulent canyon section above the mouth, eastern brook trout, longnose dace, largescale sucker, and northern squawfish were captured. Catch rates were very low for these fish. No trout YOY were found in any of the sampled sections. silted.

Stream substrates in Union creek were typically heavily 


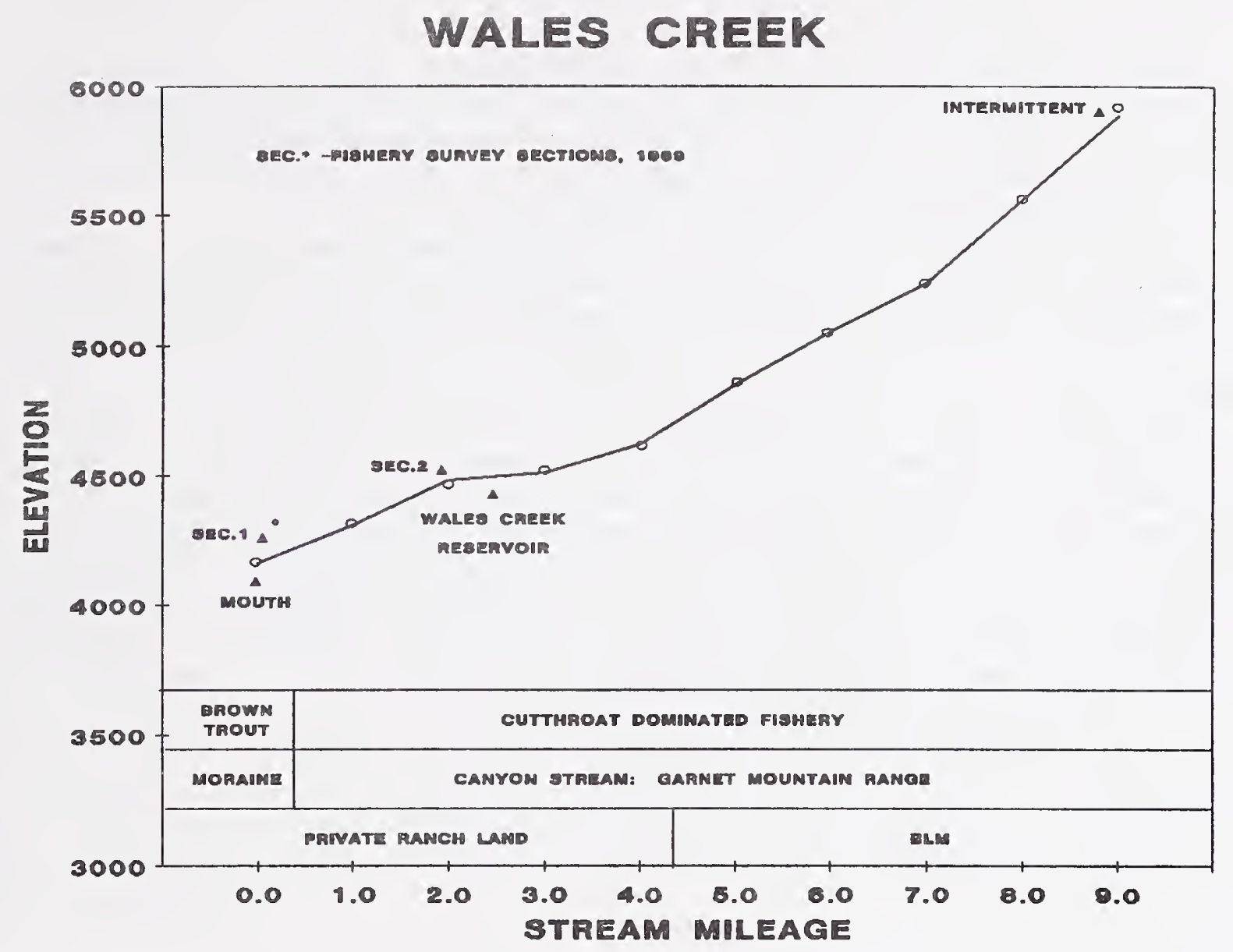

Figure 31. Stream channel gradient, land ownership, dominant trout species, stream flow characteristics, and fish sampling sections in wales Creek.

\section{Wales Creek}

Wales Creek, a 2nd order stream, originates at Chamberlain Meadows in the Garnet Range, in Powell county. It flows 9 miles northeast to its confluence with the Blackfoot River, at river mile 60.4, about 1/4 mile upstream from the Raymond Bridge. Discharge from Wales Creek was $1.4 \mathrm{cfs}$ at the mouth on September 19, 1989. Land-uses in the upper basin include: timber harvest; ranching and irrigated farmland. Livestock grazing, roads and ranching operations dominate the lower basin. Below stream mile 3.0 , the stream is accessible by an unimproved dirt road although private ownership restricts access.

In its upper basin, the stream flows through an incised Vshaped canyon on land administered by the BLM. At about mile 5.0, Wales Creek enters private land and then flows another two 
miles before entering Wales creek Reservoir, a privately owned reservoir. It flows from the reservoir two miles to its confluence with the Blackfoot River.

Near the mouth, the stream becomes confined in glacial deposits with moderate to heavily silted substrates. Gradient ranges from about 340 feet per mile in the headwaters to 35 feet per mile at the reservoir (Figure 31). The gradient increases to about 140 feet per mile near the mouth.

At the mouth, the riparian vegetation consists of alder and water birch along with sedges, nettles and mint. Upstream near the reservoir outlet, an overgrown spruce woodland dominates the vegetation with alder in the subcanopy, providing very dense stream cover.

Two sections were sampled for fish in September, 1989; a mouth section and a section just below the reservoir. In the lower section, Brown trout and cutthroat were collected. Sculpins were common (Appendix Table 3 ). Of the cutthroat captured, four of the fish were hatchery cutthroat which had moved into the tributary from the Blackfoot River. The brown trout were mostly juvenile fish. Below the reservoir, cutthroat were the only game fish collected. 


\section{DISCUSSION}

The Blackfoot River has been studied intensively for the last two years. In 1988 we focused on the Blackfoot River and in 1989 we focused on the major tributary streams. The two year effort has provided insights into the original angler concerns about the river's health. In 1988 we found that the Blackfoot River appeared to be producing far fewer trout than one would expect; that native fish species were in extremely low numbers: and the problems and characteristics of the river were extremely variable throughout the river system. In 1989 we found that the Blackfoot River has significantly deteriorated trout habitat in it's tributary streams. Most of the decline of habitat has occurred on private lands associated with agricultural activities and primarily associated with livestock grazing. The tributaries have also been impacted by overharvest of native and non-native fish stocks. In addition the Blackfoot River basin geologically exercises significant control over the resident trout populations. Glacial land forms produce the young and highly erosive drainages that produce large amounts of sediment to the stream channels. Poor reproduction and added man-caused stress on habitat and numbers of spawning adult fish appear to be at the root of the river's problems. Recent liquidation of large tracts of private commercial forest, which increases drainage sediment yields, are not in the best interest of the Blackfoot River fishery either.

\section{Blackfoot River Fish Populations}

Trout population estimates have been completed on the Johnsrud section annually from 1980 to 1985 (Peters, 1985). Since the early $1980^{\prime}$ 's the estimated density of rainbow trout > 12.0 in. TL have ranged from 9 to $45 / 1,000$ lineal ft of stream. In 1989, we estimated the Johnsrud section carried 12.5/1,000 ft; significantly less than the 1985 estimate of 45/1,000 ft. The lowest density of $9 / 1,000 \mathrm{ft}$ occurred in 1980 .

Sub-adult (size class 10.0-11.9 in. TL) rainbow trout densities in the Johnsrud section have ranged from 28 to $126 / 1,000 \mathrm{ft}$. The highest density was measured in 1981 in a midsummer sample in early August. other samples were completed earlier in May through June, which may have contributed to the greater density. A high of 54/1,000 ft for June samples occurred in 1983. The lowest density of sub-adult rainbows estimated in the Johnsrud section was $28 / 1,000 \mathrm{ft}$ in June of 1989 .

Juvenile rainbow trout (size class 5.0-9.9 in. TL) have ranged from 150 to $492 / 1,000$ ft over the 1980 to 1989 period of record. The highest density of juvenile rainbow, 492/1,000 ft occurred in 1981. The lowest density of 150/1,000 ft was estimated in 1984. Since 1984 the density of juvenile rainbow in the Johnsrud section has averaged 169/1,000 ft and prior to 1984 
$332 / 1,000 \mathrm{ft}$. The decline in juvenile fish in the Johnsrud section since 1983 coincides with cessation of Arlee rainbow trout planting in Seeley Lake in 1984. The Seeley Lake rainbow plant of about $50,000,4$ to 6 in. TL fish annually, was identified moving out of Seeley Lake down the clearwater River to the Blackfoot River in 1983.

The movement of hatchery rainbow trout from seeley lake over the wild population of rainbow trout in the Blackfoot River did very little for improving numbers of catchable-sized rainbows from 1980 to 1984 in the Johnsrud section. The planting of rainbow trout in the Johnsrud section would therefore seem to be of little value for improving the declining fish size and numbers. However the cessation of this indirect fish planting has not stimulated any noticeable improvement in the wild trout fishery either.

The low 1989 density of adult rainbow trout in the Johnsrud section is of concern. The corresponding low densities of subadult and juvenile rainbows (10.0-11.9 in. and 5.0-9.9 in. size classes respectively), will maintain low recruitment to the adult size classes over the next several years. Low stream flows in the period 1984 to 1988 probably contributed to poor recruitment to these juvenile size classes. Population estimates planned for 1990 should show greatly improved numbers of juvenile fish resulting from improved flow conditions in 1989 and 90 if low flows were a major factor. Liberal bag limits would be an added factor contributing to a depressed fishery. Peters and spoon in 1989 concluded that angler harvest was a significant factor in larger rainbow trout mortality in the lower Blackfoot River. Low numbers of spawning adult rainbows may result in a continued decline in this fishery even with greatly reduced bag limits until densities of adult rainbows recover.

Densities of cutthroat trout $>6.0$ in. TL in the Johnsrud section have ranged from 1.4 to $20.6 / 1,000 \mathrm{ft}$. The lowest densities occurred in 1981 and 1989. The highest density occurred in 1984 which coincides with the yellowstone cutthroat plants in seeley Lake. The possibility of movement from seeley Lake is evident in the identification of yellowstone cutthroats in the Blackfoot River Johnsrud section samples following that plant. The density of cutthroat declined from 10.3 in 1985 to 1.7 in 1989, following the cessation of the yellowstone plants in 1989.

Adult bull trout in low densities are consistently caught during the June Johnsrud section sampling. We captured or observed large adult fish in the 10 pound size range in the years from 1983 to 1985. However in 1989 only one large adult of about 7 pounds was captured and was subsequently taken by a fisherman based upon on a tag return. Few juvenile bull trout are seen in the Johnsrud section. In 1989 we obtained an estimate of bull trout density for fish $>6.0 \mathrm{in}$. TL. which was $1.2 / 1,000 \mathrm{ft}$. The larger adult captured and tagged in Johnsrud section in 1989 was caught and kept by an angler on the North Fork of the Blackfoot in early August. The fish was probably headed to a spawning area 
in the North Fork.

In 1988 a new mid-river fish population monitoring section was established from the scotty Brown bridge to the Russ Gates Fishing Access site. Only two estimates have been completed in the section a fall estimate in 1988 and a spring estimate in 1989. The estimated density of rainbow trout in three different size groups (4.0-10.9, 11.0-13.9, and $\geq 14.0$ in. TL) was unchanged over the winter period covered between samples. The unchanged density of 4.0 to 10.9 in. rainbows is evidence of a winter mortality or movement problem in the scotty Brown section. Peters and Spoon in 1988 reported high numbers of YOY rainbow in the Scotty Brown section similar to the Johnsrud section. Those high densities of YOY should have produced a strong yearling size group which would be grouped with the 4.0 to 10.9 in. estimated group in the 1989 estimate. No significant increase was noticed in the spring sample. In the Johnsrud section with similar YoY densities the juvenile size group had a density of 177/1,000 ft in the spring of 1989 whereas the scotty Brown section had only $28.6 / 1,000 \mathrm{ft}$. Although the YOY sampling may not be indicative of total numbers of recruits entering the population. However in defense of the method other western Montana streams show a correlation between YOY densities and older age classes density. The low density of $36 / 1,000 \mathrm{ft}$ for all three size groups of rainbow in the scotty Brown section is only $16 \%$ of the Johnsrud rainbow density. However the brown trout population $\geq 6.0$ in. TL increases almost 4 times to $23.1 / 1,000 \mathrm{ft}$ from the Johnsrud to scotty Brown sections. This increase in brown trout does not make up the difference between the trout densities between the two sections. Good brown trout spawning opportunities in cottonwood and Monture creek are suspected of improving brown trout recruitment in the Blackfoot River.

Bull trout $\geq 6.0$ in. TL densities were $2.3 / 1,000 \mathrm{ft}$ in the Scotty Brown section nearly twice the Johnsrud density but still extremely low.

\section{Headwaters Toxic Metals Problem}

High concentrations of cadmium in the liver tissue of cutthroat trout in sections of the upper Blackfoot River confirm a relationship between the collapse of the cutthroat fishery and the flush of Mikehorse mine tailings into the upper Blackfoot River. Benoit, Leonard, Christensen, and Fiandt in 1976, reported that Iiver concentrations of cadmium of $9 \pm 2 \mathrm{ug} / \mathrm{g}$ adversely affected brook trout during the stressful period of spawning. Nehring 1986 postulated that elevated levels of cadmium (13 ug/g) affected growth and survival of brown trout in Colorado's Arkansas River. In the Below Pop's Place section, river mile 129, a section immediately above cadotte creek, cadmium concentrations in cutthroat and brook trout livers average 8.8 and $9.4 \mathrm{ug} / \mathrm{g}$ (dry weight), respectively (Moore, Luoma, and Peters 1990). In the Flesher section of the 
Blackfoot River, river mile 125, located near the Flesher Pass road, cadmium concentrations in cutthroat trout liver tissue averaged $5.9 \mathrm{ug} / \mathrm{g}$ (dry weight).

In 1973 prior to the tailings pond failure the Flesher section held an estimated 69 age I and older cutthroat per 1,000 ft. In 1989 the same year classes held only 15/1,000 ft. YOY cutthroat declined from an estimated $187 / 1,000 \mathrm{ft}$ to low densities in which only 2 YOY were captured in 2 electrofishing passes in the section. The two electrofishing passes equalled the effort required in 1973 to obtain the population estimate.

Water quality remains high through most of the year within the sections impacted by the toxic tailings according to limited sampling by the state Water quality Bureau. However the toxic affects of the contaminated sediments along the stream bottom rather than within the water column appear to be causing the elevated metals concentrations in the food chain. Contaminated sediments in 1988 extend an additional 15 miles downstream from areas that were contaminated in 1975 (Moore, Luoma, and Peters 1990). Moore, Luoma, and Peters also found in 1989 that bottom sediment metals concentration and concentrations in liver of brook trout strongly correlated with $r$ squared $=0.971$. They also felt that the natural marsh (beaver pond system) system slowed the transport of metals downstream although they do not completely stop downstream contamination. The long term health of the entire Blackfoot River system will depend upon the cleanup of all metal contamination sources and acid seep sources in the headwaters. A cleanup plan that addresses all the sources of contaminants is needed at the earliest possible date. In addition existing instream deposits need to be managed to prevent additional downstream movement. No plan for managing instream toxic metals has been formulated by responsible parties.

\section{Native Fish Species Evaluations}

Bull trout population status and overall population health in the Blackfoot River have receive little attention. The native bull trout are considered a species of special concern in the State of Montana. Habitat degradation, low population densities, hybridization with brook trout, potential for overharvest and the uniqueness of this native species all contributed to the classification. This Blackfoot River fishery evaluation has provided the opportunity to collect additional information on the bull trout in the Blackfoot River.

Bull trout exceeding 12 pounds have been captured electrofishing in the Blackfoot River. Thus the bull trout is the largest fish species inhabiting the Blackfoot River. Evaluation of the bull trout throughout the clark Fork drainage above the Flathead River by Peters in 1985 revealed the highest densities of the large-sized large stream bull trout (fluvial bull trout) occurred in the Blackfoot River. In 1989 only 3 of 
19 sampled major tributaries to the Blackfoot River carrier significant densities of YOY bull trout. The lack of YOY bull trout in several streams with known spawning runs in the past could mean populations have been lost. In Monture creek, one of the 3 tributaries with significant numbers of YOY present in 1989, redd counts revealed a $59 \%$ decline from 1985 to 1988 and 1989. Observations from a long-term bull trout fisherman in the North Fork of the Blackfoot River also revealed a significant decline in numbers of redds in 1988, probably of similar magnitude to observed changes in Monture creek. In 1988 the Canyon creek fire burned in the same area and time of the bull trout spawning run which may have decreased spawning activity. However in 1989, normal stream flows and lack of the unusual fire activity still resulted in few redds. Copper Creek, tributary to the Lander's Fork, had the second highest densities of YOY bull trout of the 19 sampled tributaries in 1989. Fish sampling observations during the spring population estimates in the Blackfoot River indicate declining numbers and size of adult bull trout. The lack of more and better spawning opportunities for the large fluvial bull trout in the Blackfoot River put this unique fish species in jeopardy at this time. Harvest of the few adult and juvenile fish still in the system should be curtailed immediately. Spawning streams for bull trout should receive special land, water and fish management considerations for preservation of this species and populations.

The native westslope cutthroat is a species of special concern in the state of Montana. Populations of this species were widespread throughout western Montana's large rivers and creeks prior to the introduction of rainbow, yellowstone cutthroat, brown, and brook trout. Today cutthroat dominate most of the headwater reaches in the Blackfoot River. Throughout the range of the westslope cutthroat the species exhibits great diversity from stream to stream. Three main variations in life history have been identified throughout it's range. The first is a resident life history, the second adfluvial, and the final a large-river or fluvial. The resident life history essentially lives it's entire life cycle within a relatively short reach of stream. The adfluvial cutthroat spawns and rears in streams tributary to a lake, returning to the lake as juvenile fish, then maturing within the lake environment. The third life history, the large-river cutthroat, spawns and rears in a small tributary to a large river, then migrates to the large river system to mature. The juvenile cutthroat generally migrate to the large river system as 3 year old fish. The mature adults of this large-river cutthroat can attain sizes in excess of 20 inches in western Montana waters. Low densities of relatively large cutthroat found in the Blackfoot River and cutthroat first observed in the Blackfoot River sampling sections as 3 year olds are suspected to be remnant large-river cutthroat. The two suspected types of cutthroat found in the Blackfoot River tributaries cannot be separated visually which creates a real 
dilemma. Protection of the large-river fish will require protection of resident populations until and if better

information makes the distinction possible by drainage, location or some other means. The other alternative is to disregard the existence of the two types and probably eventually eliminate the large-river fish.

In some identified mountain streams cutthroat have developed adaptive behavior to survive natural and annually occurring calamities. Peters 1988 found that cutthroat in the west Fork of Rock Creek migrated out of $100 \%$ sand bottomed reaches and reaches that developed excessive winter anchor ice. Anchor ice is known to cause high winter mortality of trout. Large sections of the Blackfoot River have severe annual anchor ice problems (Peters and spoon 1990). Cutthroat trout endemic to those waters having evolved with the environments should provide the best possibility of surviving and thriving with the harsh conditions. High YOY mortality of rainbow in the scotty Brown section may be a result of behavior that results in mortality. This section of the Blackfoot experiences severe winter anchor ice conditions.

Resident populations of cutthroat trout occur in the headwaters of all the major tributaries to the Blackfoot River. spatial isolation from the non-native rainbow and brown trout occurs within a mile to about 5 miles of the mouths of the major tributary streams depending on the specific stream system. The isolation appears to be environmentally controlled rather than physical barrier related since migration barriers do not occur within the species transition zones sampled in 1989. Of the 19 tributary streams sampled only Chamberlain, Gold, and Poorman Creeks carried good densities of cutthroat trout. Low densities, high catch rates by fisherman, gullibility, competition with nonnative species, loss of habitat, and hybridization with rainbow trout have contributed to the decline of westslope cutthroat. However with improved management of cutthroat in the Blackfoot River significant improvement in cutthroat populations may occur.

Tributary Stream Evaluations

\section{Arrastra Creek}

Arrastra creek flows into the Blackfoot River in a reach with identified recruitment problems. Arrastra creek could provide additional spawning opportunities in the canyon section of the Blackfoot River. Beaver activity near the mouth appears to limit the spawning opportunities of the fall spawning brown trout. However beaver appear to have been a natural part of the system for a long period of time that have only recently begun to re-establish influence on the stream environment. The success of 
establishing better brown trout spawning would require removal of the beaver. Another approach would be to try and re-establish runs of spring spawning and migrating native fish species that have less problem with beaver dam navigation.

other factors that also influence the fish population in Arrastra creek include: intermittent stream flow starting at about stream mile 2, livestock over-use of banks, possible fish barrier culvert at the forest road, siltation of substrates and possibly overharvest in the past.

\section{Beaver Creek}

Beaver creek is a good small tributary to the Blackfoot River in the Lincoln area. The lower reach is a brown trout dominated fishery and upper a pure westslope cutthroat fishery. siltation aggravated by livestock grazing on the banks in the middle reaches could be addressed. The private landowner indicated a willingness to improve the bank conditions. The upwelling of ground water in the Blackfoot River in this area has attracted brown trout spawners and probably as a result does not seem to suffer from a shortage of recruitment.

\section{Belmont Creek}

In the lower reaches livestock grazing in the stream side zone has trampled banks and is probably a factor in the widened channel. In the spring of 1990 the culvert for the main road along the Blackfoot across Belmont creek was blocking rainbow trout spawners. Fall spawning fish are probably similarly blocked. This stream passage problem should be fixed.

In the headwaters the substrates are heavily silted. Intensive logging and poor stream side harvest practices appear to be the major contributor to this problem. Pure westslope cutthroat and bull trout are suspected in the headwaters.

\section{Chamberlain creek}

Chamberlain creek had the highest density of cutthroat trout of all tributary streams sampled. Intensive logging and poor stream side management practices have added extra silt loads to the channel. In 1990 a poorly installed culvert washed out a roadway in the West Fork of Chamberlain Creek and noticeably increased turbidity in Chamberlain creek. Turbidity measurements taken by the BLM on April 1,1990 recorded 85 NTU's near the mouth of the West Fork and 4.5 NTU's upstream of the West Fork in Chamberlain creek. Investigation by Fish, Wildlife and Parks personnel into the source of the turbidity revealed a poorly installed culvert on a logging road and stream alterations were causing severe erosion and the turbidity problem. 
The owner of the mouth of Chamberlain Creek has the capability of enhancing stream flows, fish habitat, and the Blackfoot River by maintaining and enhancing trout migration into Chamberlain creek. Past road crossings with culverts and diversions on the property may be fish passage barriers.

\section{Clearwater River}

The Clearwater River near the outlet of Salmon Lake is too warm for a resident trout fishery. The downstream impacts of the surface water lake drainage probably extend to nearly the mouth of the clearwater River a distance of 10 miles. The feasibility of decreasing water temperatures with a multi-level lake drain should be explored along with the feasibility of introducing a river dwelling coolwater species such as smallmouth bass. The productive lake water drainage should produce highly productive gamefish fisheries in both instances. The feasibility of decreasing temperatures would of course be more meaningful to the Blackfoot River fishery. A drain of cooler lake water would probably produce a tailwater type of fishery in the clearwater River. Several well known tailwater fisheries in Montana the Missouri River, Beaverhead, and Big Horn are examples of enhanced production below impoundments. The mesotrophic condition of Salmon and seeley Lake would provide the productive potential to the clearwater River.

The lower Clearwater River provides spawning and rearing opportunities for brown and rainbow trout. Groundwater inflows near the mouth are suspected to moderate the high summer water temperatures coming from Salmon lake. An irrigation headgate near HWY 200 removes a significant amount of late summer stream flows from the clearwater River. This water withdrawal may actually help moderate the late summer temperatures near the mouth by increasing the percentage of stream flow contributed by the cooler groundwater inflow (Pers. comm. Ron spoon).

\section{Copper Creek}

Copper creek contained the second highest densities of bull trout YOY of the 19 major tributaries sampled in the Blackfoot drainage in 1989. The drainage has been heavily logged and roaded but limited streamside logging has maintained woody debris recruitment and quality fish habitat. Plans for intensified stream side tree harvest without consideration for woody debris recruitment and the sediment loading are of special concern. The known high sensitivity of bull trout to sediment loading and the current status of bull trout in the Blackfoot should be a major consideration in forest management decisions in copper creek.

Low densities of gamefish in the Lander's Fork may also be enhanced with the recovery of gamefish in Copper creek. Copper creek has high quality spawning and rearing habitat that appears 
under utilized.

Cottonwood Creek

cottonwood creek is a spawning stream for brown and rainbow trout from the Blackfoot River. Beaver dam activity near the mouth is limiting access of the spawners to about one quarter mile of the creek. Additional high quality spawning areas could be opened up to spawning with a beaver control program at the mouth. The private landowner has indicated a willingness to cooperate in such a program. Increased beaver activity on the Blackfoot Clearwater Game Range portion of Cottonwood Creek has created additional upstream migration barriers.

In the upper reaches agricultural water withdrawals and natural losses to underground aquifers dewater segments of the stream channel. The purchase of the Dryer ranch by MTDFW\&P in 1990 may provide a means to improve stream flows in the upper reaches.

\section{Gold Creek}

Gold Creek sustains spawning runs of rainbow, brown, and bull trout from the Blackfoot River. Gold creek had the highest densities of YOY rainbow trout of the 19 sampled tributaries. The good densities of YOY and juvenile trout in the Johnsrud section of the Blackfoot River are suspected to be a result of the role of Gold Creek in producing them. Heavy commercial logging has taken place in the last decade in the Gold Creek drainage. Wilderness in the headwaters provide some buffer from the land clearing activities.

\section{Lander's Fork}

The Lander's Fork is a cutthroat/bull trout stream with extremely low densities of each. A heavy bedload produces frequent channel changes in the lower and middle reaches. The cutthroat population is suspected to have been severely overharvested. The Lander's Fork is a low productivity type of stream naturally. The native cutthroat, whitefish, and bull trout are able to survive and grow to relatively large sizes only through living many years in the system. A fisherman's log on the Lander's Fork near the turn of the century indicated a good cutthroat fishery once resided in the stream. Individual cutthroat to 18 inches of length are not uncommon in the record. The increase in popularity of fishing and the limited capability of this type of cutthroat fishery to sustain even limited harvest are the leading reason for the current poor condition of this fishery. If good local compliance with catch and release regulations occurs this fishery can improve greatly. Even a limited harvest will keep this fishery in poor condition because 
of limited productivity of the stream. The native cutthroat have great capability to grow rather large in these unproductive waters if unharvested. Many examples are available throughout the range of the westslope cutthroat. An increase in larger sized cutthroat should increase recruitment and help fill the available fish habitat that is currently vacant.

\section{Monture Creek}

Monture creek is an important spawning tributary to the Blackfoot River for rainbow, brown, cutthroat, and bull trout. Monture Creek had the third greatest densities of YoY bull trout in the Blackfoot drainage. The stream carries a heavy sediment load naturally. Bull trout spawning success is probably related to the groundwater upwelling occurring in specific reaches. Brook trout also occur within the reach of heaviest known bull trout spawning and hybridization could cause demise of the bull trout as described by Leary, Allendorf, and Knudsen in 1983. The aggressive nature of the large fluvial bull trout (pers. comm. with Robb Leary) may prevent hybridization from occurring.

Heavy woody debris recruitment in Monture creek appears to be the key to the success of bull trout. The debris loading produces debris jams that carve deep pools with excellent large fish habitat, necessary for a fish the size of a bull trout. Considering the fishes early fall, low flow spawning period excellent cover is a prime prerequisite to successful survival. In 198527 bull trout redds were counted in the best known spawning area. In 1988 and 1989 the same section produced only 11 and 8 redds respectively, a disturbing trend. Closure of all known bull trout spawning areas from fishing is indicated by low numbers of adults and juveniles.

Throughout all sampled sections catch rates for both adult and juvenile trout seemed low for the available habitat.

Some reaches in the lower end of the stream have had excessive stock trampling on the banks.

\section{Nevada Spring Creek}

This spring creek flows into Nevada creek at stream mile 6.4 which then empties into the Blackfoot River at river mile 67.8 . The Blackfoot River has an identified recruitment problem in this reach. Nevada Spring Creek is currently in a severely degraded condition from years of livestock grazing and trampling of the banks along with stream channel siltation caused by damming of the channel. The major landowner on Nevada Spring Creek has been cooperating in plans to improve fish habitat and fence the banks. Nevada Spring creek has great potential in increasing recruitment to the Blackfoot River in a reach that severely needs it. 


\section{Nevada Creek}

Nevada Creek flows into the Blackfoot River at river mile 67.8. The lower 10 miles of Nevada Creek has severe silt problems and appears to be delivering high water temperature to the Blackfoot River. At the mouth Nevada creek contributed 39.7 percent of the flow of the Blackfoot River in November, 1989. Poor quality water from Nevada Creek probably contributes to the poor fishery in the Blackfoot River found in the reach below Nevada Creek.

Landowners in the area appear willing to work on the problems of the creek to help restore a viable fishery.

The possibility of maintaining cooler summer water temperatures with modification of the Nevada Creek reservoir outlet should be explored. A stream restoration project should be put together for Nevada Creek which addresses the major fishery problems and landowner concerns and needs.

\section{North Fork of the Blackfoot River}

The North Fork of the Blackfoot River nearly doubles the flow of the Blackfoot River. On August 16, 1989 the North Fork was discharging $300 \mathrm{cfs}$ near the mouth. Cold water inflows from the North Fork significantly decrease water temperatures in the Blackfoot River. In 1988 water temperatures above the North Fork reached levels that are considered stressful to the trout (Peters and Spoon, 1989).

The North Fork below river mile 9 gains significant amounts of groundwater inflows. At river mile 6.2 a major spring creek system enters the North Fork, which added 78 cfs in the summer of 1989 to the North Fork.

Fish populations in the North Fork are generally in low densities. Overharvest of native fish species and loss of spawning and rearing habitat are suspected to be the primary reason for poor fish densities. Naturally low productivity water contributes to the overharvest problem. The North Fork is prime cutthroat and bull trout habitat. The cold summer temperatures and winter conditions are suspected of limiting rainbow and brown trout colonization upstream of the spring creek system at river mile 6.2.

\section{Poorman Creek}

Poorman Creek flows into Grantier Spring creek about 1/8 mile from the Blackfoot River. Irrigation and natural subsurface water losses contribute to the creeks intermittent status in the lower 3 miles. Pure westslope cutthroat have been identified in the upper reaches of Poorman creek. Poorman Creek carries a good population of cutthroat trout. The private landowner of the lower creek has the potential to enhance summer flows in the 
lower creek and possibly enhance Blackfoot River tributary spawning opportunities in Poorman creek.

\section{Rock Creek}

Rock Creek is a spring type creek that flows into the North Fork at river mile 6.2. Rock Creek has a tributary, named Ginoff or Klienschmidt Creek, which is also a spring creek. The tributary enters Rock Creek immediately above the HWY 200 culvert. The discharges of Rock Creek and Ginoff Creek were respectively 53 cfs and 25 cfs in July, 1989. Flows were noticeably less in the spring of 1990 which is normal according to the landowner at the mouth. Several events have severely reduced the fishery values in this creek. A large culvert installed during the initial routing of HWY 200 severely altered the lower creek and produces high velocities capable of limiting fish migration. Additional culverts located on the privately owned lands may also have impeded fish migrations. Loss of fish spawning in the creek prompted landowner efforts to improve fish habitat. Their good faith efforts included building small dams along the spring creeks to "improve" fish holding pools. The low gradient of the spring creek and lack of high flushing flows encouraged the siltation of substrates behind the dams and probably further degraded fish habitat. Stream side brush and tree removal, removal of large trees from the channel (woody debris), diversion of water for a commercial fish hatchery, , stream-side grazing and tillage also reduced fish productivity and habitat. The major private landowner has been very cooperative in discussions and efforts to restore fish habitat to this spring creek system. The restoration of this spring creek has great potential for improving recruitment in the Blackfoot and North Fork of the Blackfoot River. North Fork brown and rainbow trout populations probably rely on this spring creek system for recruitment. Low densities are probably a result of low recruitment from the spring creek system.

\section{Union Creek}

Union Creek flows into the Blackfoot River at river mile 12.9 immediately above the McNamara bridge. The fishery is extremely depressed and suffers from a number of habitat problems. The BLM is currently evaluating sources of sediment in the drainage which contribute to the stream's turbid appearance most of the time. Union creek was responsible for high turbidity levels in the Blackfoot on at least two occasions during the summer of 1989. Local sources indicate that Union Creek once supported a good trout fishery. Water and land use practices on the creek appear to be the main problem in restoration of the creek's trout fishery. Concrete water drop structures in the 
creek prevent upstream migration of trout. The structures were placed in the creek without regard for migrating fish and should be altered to allow passage. They also have contributed to sedimentation of the creek's rearing and spawning substrates. Union Creek landowners contacted in 1989 indicated a willingness to improve the trout fishery in union creek.

\section{Wales Creek}

Wales Creek flows into the Blackfoot River at river mile 60.4 about 1/4 mile above the Raymond bridge. Wales Creek reservoir located at about stream mile 3 stops upstream migration of Blackfoot River spawning fish. The reservoir is used for irrigation and stream flows below the reservoir were extremely low in 1989. Flowing into the Blackfoot River in one of the rivers worst sections, Wales creek could provide significant spawning opportunities for Blackfoot River fish as well as a source of cold water to alleviate summer water temperature problems.

The new owner of the surrounding land and water rights appears to be willing to expand his land use goals to include both fish and wildlife management in the drainage. 


\section{MAJOR FI8H SPECIES MANAGEMENT PLANS}

The Blackfoot River and tributary streams contain wild populations of rainbow, brown, brook, cutthroat, and bull trout. These populations vary considerably in species composition, density, and limiting factors from one reach of the river to another and one tributary to another. The two native trout species, westslope cutthroat and bull trout, are in extremely low densities throughout the drainage. Maintenance of viable wild populations of rainbow, brown, bull and cutthroat trout is in question at the low densities currently found in the Blackfoot and tributaries.

In order to develop a meaningful plan to restore trout populations in the Blackfoot River and tributaries the following problems, goals and objectives statements have been developed for each species.

\section{WESTSLOPE CUTTHROAT TROUT}

The Blackfoot River and it's major tributaries have the potential for greatly enhanced populations of cutthroat. Two major variations in cutthroat identified in most western areas where cutthroat are endemic also occur in the Blackfoot. One variation lives in smaller tributary streams it's entire life cycle. The other variation, a "large river" cutthroat spawns and rears in the small tributary streams to eventually migrate to the large river for growth and maturation. We have collected some of these large river cutthroat in all sections of the Blackfoot and collect the out-migrating 3 year old's regularly in the spring electrofishing. The Blackfoot River has the capability to produce cutthroat 20 inches long based upon historical accounts. Slow growth rates and environmental limiting factors are key factors leading to over-harvest of this fish stock. over-harvest causes failure to reach full length growth potential and full recruitment potential in the Blackfoot. High background sediment loads and an increase in sediment loading from commercial timber harvest in the drainage, the Canyon Creek Fire of 1989 and other factors are expected to make the cutthroat population even more sensitive to over-harvest by anglers.

The average density for cutthroat larger than 6 inches from the mouth to Lincoln is 1.8 per 1,000 feet in the Blackfoot River.

Key spawning stream populations of cutthroat sampled in 1989 indicate very low densities of young-of-the-year (YOY) cutthroat and poor adult populations. Cutthroat and bull trout are isolated from other species spatially in all sampled tributary streams, occupying reaches farther upstream from the mouth than the rainbow and brown trout. YOY cutthroat size also indicate a temporal isolation, spawning after the rainbow trout. 
Upstream from Lincoln cutthroat populations have crashed since the Mike Horse mine tailings pond failure in 1975. Efforts are in progress to clean up mining problems. At present no harvest of cutthroat can be sustained in this reach.

Cutthroat Trout Management Objective for Blackfoot River: Increase populations of cutthroat larger than 6 inches in the Blackfoot River to 100 fish per $1,000 \mathrm{ft}$.

\section{STRATEGIES:}

1. CATCH AND RELEASE REGULATION ON BLACKFOOT RIVER AND TRIBUTARY STREAMS FOR CUTTHROAT.

- PROTECTS ADULT SPAWNERS AND JUVENILE REARING FISH

- JUVENILE REARING CUTTHROAT MOVE TO BLACKFOOT AS 3 YEAR OLD'S

- CUTTHROAT GULLIBLE AND EASY TO CATCH FOR ALL ANGLERS SHOULD INCREASE CATCH RATE AFTER RECOVERY

- CUTTHROAT LOW SPAWNER POPULATIONS THREATEN REPRODUCTION SUCCESS IN SMALL TRIBUTARIES.

- NEED ALI AVAILABLE WILD FISH FOR RECOVERY EFFORTS

- RE-INTRODUCTIONS NEED PROTECTION FROM HARVEST

- CUTTHROAT ARE DISTINCTLY IDENTIFIABLE IN BLACKFOOT

2. IMPROVE SPAWNING AND REARING HABITAT WHERE NEEDED.

- 1989 SAMPLING FOCUSING ON HABITAT IN KEY TRIBUTARIES

- MUST HAVE AVAILABLE SPAWNING FISH TO DO ANY GOOD (STRATEGY NUMBER 1)

3. RE-ESTABLISH SPAWNING RUNS IN IDENTIFIED VACANT HABITAT.

- TEST IF HABITAT AVAILABLE IS SUITABLE WITH PLANT OF NATIVE SPECIES

- ALREADY STARTED THIS PROGRAM IN NORTH FORK AND BLACKFOOT

- LIBERAL LIMITS MAY MASK SUCCESSFUL FISH PLANTS

- PROJECTED RECOVERY OF CUTTHROAT FISHERY YEAR 2000

4. SAMPLE CUTTHROAT AND BROOK TROUT, STREAM BOTTOM SEDIMENTS, AND AQUATIC INSECTS FOR TOXIC METALS CONCENTRATIONS IN SUSPECT AREAS

\section{BULL TROUT}

The Blackfoot River and tributary streams have provided the habitat necessary to produce bull trout to 15 pounds in size. These fish spawn and rear in the tributary streams then migrate to the river to attain the large sizes and maturation. Fisherman pursuit of the bull trout has been limited but increasing interest over the last 10 years has been noticed by the long time 
anglers utilizing this fish. Two monitored spawning runs have had a $59 \%$ decline in redds in the last 5 years. One stream had 8 redds in 4 mile long section the other 11 in a 5 mile reach in 1989. Other tributaries were known to have lesser runs with only a couple of spawning pairs. These runs cannot afford any

harvest. In 1989 we failed to collect any bull trout larger than 7 pounds in the Blackfoot, the first time this has happened. The average density of bull trout larger than 6 inches in the Blackfoot River is 0.1 per $1,000 \mathrm{ft}$.. Adult fish densities average about 0.05 fish per $1,000 \mathrm{ft}$.

Bull Trout Management objective for the Blackfoot River: Increase the standing crop of adult bull trout larger than 5 pounds to $1 \mathrm{fish}$ per $1,000 \mathrm{ft}$.

\section{STRATEGIES:}

1. CATCH AND RELEASE REGULATION ON BLACKFOOT RIVER AND TRIBUTARY STREAMS FOR BULL TROUT.

- PROTECTS ADULT SPAWNERS AND JUVENILE REARING FISH

- JUVENILE REARING EVENTUALLY MOVE TO BLACKFOOT

- HIGHLY VULNERABLE FALL SPAWNING IN SMALL TRIBUTARIES

- BULL TROUT LOW SPAWNER POPULATIONS THREATEN REPRODUCTION SUCCESS IN SMALL TRIBUTARIES, SPAWNER USE OF SPAWNING AREAS DECLINED $60 \%$ FROM EARLY 1980'S TO 1989.

- SOME HARVEST MAY BE APPROPRIATE AFTER RECOVERY, PROJECTED RECOVERY IS THE YEAR 2,000

2. IMPROVE SPAWNING AND REARING HABITAT WHERE NEEDED.

- 1989 SAMPLING FOCUSING ON HABITAT IN KEY TRIBUTARIES

- MUST HAVE AVAILABLE SPAWNING FISH TO DO ANY GOOD (STRATEGY NUMBER 1)

3. RE-ESTABLISH SPAWNING RUNS IN IDENTIFIED VACANT HABITAT.

- HOPEFULLY REMNANTS STILL IN SYSTEM TO REPOPULATE

\section{RAINBOW TROUT}

Rainbow trout are the dominate trout species in the Blackfoot River below Monture creek. Lower reaches of tributary streams provide the bulk of spawning opportunity for these fish. Most rainbow YOY appear to leave the tributary streams shortly after hatching. The average size rainbow trout caught in 1988 was 9 inches with a catch rate of 0.73 rainbows per hour $(0.46$, caught and released, 0.27 , kept). Anglers release smaller fish (< 9 inches) and tend to keep larger fish (greater than 9 inches). Rainbow trout larger than 11 inches accounted for $22 \%$ of the total angler catch. 
In the Blackfoot below Belmont Creek (river mile 21.9) large numbers of sub-catchables, low population estimates of fish in catchable sizes, and harvest rates in catchable sizes approaching $70 \%$ would indicate a harvest limited rainbow population.

Above Belmont Creek the rainbow population larger than 11 inches has an average density of $13 \mathrm{fish}$ per 1,000 ft.. However unlike the lower 21 miles of the Blackfoot, the juvenile fish segment of the rainbow population is also depressed. A loss of YOY during the winter appears to be primarily responsible for the lack of better yearling and older numbers. This juvenile fish loss makes this population extremely sensitive to angler harvest and reduces harvestable numbers. Environmental variables favoring the native fish species is suspected to be the cause of the juvenile fish mortality during the winter months.

Rainbow Trout Management objective for the Blackfoot River: 1. Mouth to Belmont creek (Lower 21 miles), Increase the opportunity to catch rainbow trout larger than 12 inches by increasing the population of rainbow trout larger than 12 inches to 100 per 1,000 ft from 12.4 per $1,000 \mathrm{ft}$.

2. Above Belmont Creek, Increase the opportunity to catch rainbow trout larger than 12 inches by increasing the population of rainbow trout larger than 12 inches to 50 per 1,000 ft from 0.5 per $1,000 \mathrm{ft}$.

\section{STRATEGIE8:}

1. REDUCE HARVEST OF RAINBOW TROUT WITH A 3 FISH LIMIT FOR FISH LESS THAN 12 INCHES AND CATCH AND RELEASE ON FISH LARGER THAN 12 INCHES FOR THE BLACKFOOT AND KEY SPAWNING STREAMS. BAIT AND ARTIFICIAL LURES ALLOWED.

- WILL INCREASE NUMBER OF SPAWNING AGE FISH IN POPULATION AND AVERAGE SIZE CAUGHT TO 12 INCHES

- ANGLERS WILL NEED TO LEARN METHODS OF RELEASING FISH ALIVE, INCLUDING BAIT ANGLERS

- DOES NOT REDUCE TAKE-HOME OF FISH SIGNIFICANTLY AMONG "AVERAGE" ANGLERS. "AVERAGE" ANGLERS CATCH LESS THAN 3 FISH NOW. SHOULD INCREASE CATCH OF "AVERAGE" ANGLER.

2. IMPROVE KEY SPAWNING HABITAT WHERE POSSIBLE.

\section{BROWN TROUT}

Brown trout are the dominate trout species in the Blackfoot from Lincoln to Monture creek. The lack of tributary spawning 
access appears to favor the main river spawning brown trout. Stream habitat from river mile 67.8, near Nevada Creek, to river mile 45.9, near Monture creek appears to have more

characteristics of cutthroat/rainbow habitat than brown trout habitat. Lack of recruitment sources for rainbow and cutthroat probably favor the current brown trout dominance in this reach. Upstream from Nevada Creek to Lincoln a strongly meandering pattern and good tree recruitment to the channel result in good brown trout habitat with excellent overhead cover. However this reach of river contains large quantities of sediment which greatly limits production of fish organisms and prey species for the brown trout.

In the Blackfoot River below Monture creek brown trout average about $20 \%$ of the total trout population decreasing in relative abundance to $3 \%$ below Belmont creek. The habitat in this section favors rainbow/cutthroat with a preponderance of riffle, runs, and pools with little overhead structure. The density of brown trout larger than 6 inches downstream of Monture Creek averages 23.1 per $1,000 \mathrm{ft}$.

The density of brown trout larger than 8 inches averages about 20 fish per 1,000 ft from Lincoln to Monture creek. This is comparable to estimates made in the early 1970's. However numbers of yearling brown trout have declined significantly.

Brown Trout Management objective for the Blackfoot River:

1. Lincoln to Monture Creek, maintain population of brown trout larger than 8 inches at a density of at least 20 fish per 1,000 ft.

2. Monture creek to mouth, maintain population of brown trout larger than 8 inches at a density of at least 20 fish per 1,000 ft..

\section{STRATEGIES:}

1. REDUCE HARVEST OF BROWN TROUT WITH A 3 FISH LIMIT FOR FISH LESS THAN 12 INCHES AND CATCH AND RELEASE ON FISH LARGER THAN 12 INCHES FOR THE BLACKFOOT AND TRIBUTARIES. BAIT AND ARTIFICIAL LURES ALLOWED.

- SAME REGULATION AS THE RAINBOW TROUT FOR SIMPLICITY

- BROWN TROUT COULD STAND GREATER HARVEST THAN THIS

- MAY WANT GREATER HARVEST TO ENHANCE NATIVE TROUT SPECIES RECOVERY ALTHOUGH HARVEST IS PROBABLY NOT MAJOR

DETERMINATE IN BROWN POPULATION DENSITY

- ANGLERS WILL NEED TO LEARN METHODS OF RELEASING FISH ALIVE, INCLUDING BAIT ANGLERS

- DOES NOT REDUCE TAKE-HOME OF FISH SIGNIFICANTLY AMONG "AVERAGE" ANGLERS. "AVERAGE" ANGLERS CATCH LESS THAN 3

- MOST BROWN TROUT WATERS CURRENTLY HAVE EXTREMELY LOW POPULATION DENSITIES 


\section{IITERATURE CITED}

Benoit, D.A., E.N. Leonard, G.M. Christensen, and J.T. Fiandt 1976. Toxic effects of cadmium on three generations of brook trout (Salvelinus fontinalis). Trans. Amer. Fish. Soc. $105(4): 550-560$.

Leary, R.F. and F.W. Allendorf 1989. Genetic divergence among westslope cutthroat populations in the Blackfoot River, Little Blackfoot River and Missouri River drainages. Div of Biological Sciences, Univ. of Montana, Missoula, MT.

Leary, R.F., F.W. Allendorf, and K.L. Knudsen 1983. Identification of natural hybrids between brook trout and bull trout. Genetics Report 83/2. Dept. of Zoology, Univ. of Montana, Missoula, MT. 25 pp.

Moore, J.N., Luoma, S.M. and Peters, D. 1990. Downstream effects of mine effluent on an intermountain riparian system. Submitted for publication to Canadian Journal of fisheries Research.

Nehring, R.B. 1986. An evaluation of the possible impacts of heavy metal pollution on the brown trout population of the upper Arkansas River. Colorado Div. of Wildlife. $19 \mathrm{pp}$.

Peters, D. 1985. Inventory and survey of the lower Clark Fork, Blackfoot and Bitterroot Rivers. MT. Dept. of Fish, Wildlife and Parks. Missoula, MT. 29 pp.

Peters, D. 1985. Current status of bull trout in the headwaters of the Clark Fork River, Montana. Presentation at Flathead River Basin bull trout biology and population dynamics modeling information exchange; July 24-25, 1985.

Peters, D. 1988. Third year evaluation of sediment and fish populations in selected tributaries in Rock creek and the Bitterroot River drainage. Montana Dept. of Fish, Wildlife, and Parks. $21 \mathrm{pp}$.

Peters, D. and R. Spoon 1989. Preliminary fisheries inventory of the Big Blackfoot River. Montana Department of Fish, Wildlife, and Parks, Missoula, MT. 46 pp.

Ricker, W.F. 1975. Handbook of Computations for Biological Statistics of Fish Populations. Fish. Res. Bd. Canada, Bulletin 119. 300 pp. Press, New York, N.Y. 506 pp. 
Seber, G.A.F. 1982. The Estimation of Animal Abundance and Related Parameters, 2nd Edition, Griffin Press.

Spence, L. E. 1975. Upper Blackfoot River Study: A premining inventory of aquatic and wildlife resources. Montana Dept. of Fish and Game. 85 pp.

U.S.G.S., 1987. Water Resource Data, Montana Vol. 2, 1987.

Van Deventer, J.S. and W.S. Platts 1983. Sampling and estimating fish populations from streams. Trans. of the North American Wildlife and Natural Resources Conference 48:349-354. 
APPENDIX

FISH SAMPLING STATISTICS

STREAM DISCHARGE

FIN CLIP CODING 

Appendix

Table 1. Summary of fin clips used on the Blackfoot tributaries, 1989.

\begin{tabular}{|c|c|c|}
\hline stream & Species & Number \\
\hline
\end{tabular}

Arrastra creek

LL

right pectoral

65

$\mathrm{Eb}$

14

ct

12

Beaver Creek

DV

right pelvic

2

IL

$\mathrm{Eb}$

ct

Belmont creek

$\mathrm{Rb}$

LL

Ct

82

DV

Chamberlain creek

$\mathrm{Rb}$

LL

$\mathrm{Eb}$

ct

Clearwater River

$\mathrm{Rb}$

Copper Creek

LL

ct

cottonwood Creek

DV

$\mathrm{Rb}$

LL

$\mathrm{Eb}$

ct

Gold Creek

DV

$\mathrm{Rb}$

LL

Eb

24

right pelvic

81

145

2

49

28

right pelvic and adipose 4

left pectoral and adipose 25

right pelvic and adipose 117

30

left pectoral and adipose 14

left pelvic

ct

DV

Lander's Fork

North Fork of the

Ct

Blackfoot River

$\mathrm{Rb}$

LL

$\mathrm{Eb}$

ct

DV

Monture Creek Rb

LL

$\mathrm{Eb}$

ct

DV

Poorman Creek Eb

Ct

DV

Rock and Ginoff Rb

Creeks

LL

Wales Creek

LL

ct

left pelvic and adipose

Both pelvic fins

right pelvic

left pectoral

left pelvic

left pelvic and adipose 
APPENDIX

TABLE 2. Density of young-of-the-year salmonids in tributary streams sampled in late summer and early fall of 1989 with electrofishing gear.

Sampling

\begin{tabular}{lrrrrr} 
Section & Rainbow & Cutthroat & bull & brook & brown \\
\hline Union Cr & & & & & \\
RM 0.6 & 0.00 & 0.00 & 0.00 & 0.00 & 0.00 \\
RM 7.2 & 0.00 & 0.00 & 0.00 & 0.00 & 0.00 \\
RM 10.8 & 0.00 & 0.00 & 0.00 & 0.00 & 0.00
\end{tabular}

Gold $\mathrm{Cr}$

RM 0.1

RM 3.0

RM 5.7

RM 9.0

RM 10.6

5.80

0.94

0.00

0.00

0.00

0.66

0.07

0.00

0.00

0.00

0.00

0.33

0.10

RM 3.5

Cottonwood $\mathrm{Cr}$

RM 0.0

RM 1.0

RM 3.3

RM 12.4

RM 15.9
0.88

0.18

0.00

0.00

0.00

0.00

0.00

0.09

0.00
0.00

0.00

0.00

0.00

0.79

0.26

0.05

0.00

0.00

0.00

0.00

0.00

0.08

0.00

0.00

0.00

0.00

0.00

0.00

0.05

0.25

0.00

0.73

2.00

2.87

0.00

0.02

0.00

0.02

0.04

0.00

0.00

0.00

0.00
0.00

0.00

0.00

0.00

0.00

0.05

0.06

0.18

0.00

0.00

0.00

0.08

0.00

0.00

0.00

0.00

RM 3.8

\begin{abstract}
0.00
\end{abstract}


Sampling

Section

Rainbow cutthroat

Bul1

Brook

Brown

Monture Cr

$\begin{array}{lrlllll}R M & 0.4 & 0.21 & 0.02 & 0.00 & 0.00 & 0.04 \\ R M & 2.2 & 0.27 & 0.00 & 0.00 & 0.18 & 0.33 \\ R M & 5.4 & 0.02 & 0.01 & 0.04 & 0.09 & 0.07 \\ R M & 8.6 & 0.00 & 0.04 & 0.03 & 0.06 & 0.00 \\ R M & 12.9 & 0.00 & 0.06 & 0.07 & 0.16 & 0.00\end{array}$

North Fork Blackfoot

$\begin{array}{lrl}R M & 2.6 & 0.25 \\ R M & 4.0 & 0.00 \\ R M & 7.9 & 0.00 \\ R M & 11.5 & 0.00 \\ R M & 17.2 & 0.00\end{array}$

0.00

0.00

0.00

0.12

0.00

0.00

0.00

0.00

RM 7.9

0.00

0.33

0.00

0.00

RM 17.2

0.01

0.21

0.00

0.00

0.12

0.00

0.00

Rock (spring cr)

RM 0.0

0.03

0.00

0.00

0.00

0.03

0.18

RM 0.3

0.88

0.00

0.09

0.93

RM 0.7

0.68

0.00

0.00

0.14

0.94

RM 1.2

0.00

0.00

0.00

0.93

0.15

$\mathrm{RM} \quad 1.4$

0.00

0.00

0.00

0.67

0.05

0.00

0.56

0.03

Ginoff (spring $\mathrm{cr}$ )

\begin{tabular}{lll}
\hline $\mathrm{RM}$ & 0.00 & 0.03
\end{tabular}

0.00

0.00

0.03

0.18

Wales Cr

RM 0.0

0.00

0.00

0.00

0.00

0.38

RM 1.9

0.00

1.07

0.00

0.00

0.00

Nevada Spring $\mathrm{Cr}$

RM 0.8

0.00

0.00

0.00

0.00

0.02

Arrastra Cr

\begin{tabular}{|c|c|c|c|c|c|}
\hline 0.5 & 0.00 & 0.00 & 0.00 & 0.00 & 0.61 \\
\hline 1.1 & 0.00 & 0.21 & 0.00 & 0.26 & 0.26 \\
\hline 2.4 & 0.00 & 0.00 & 0.00 & 0.00 & 0.00 \\
\hline
\end{tabular}


APPENDIX

TABLE 2.

(cont.)

Sampling

Section

Rainbow cutthroat

Number of YOY $/ 10 \mathrm{ft}$

Keep Cool Cr

RM 1.0

0.00

0.00

0.00

0.00

0.02

Spring $\mathrm{Cr}$

$\mathrm{RM} \quad 0.4$

0.00

0.00

0.00

0.00

0.36

Beaver $\mathrm{Cr}$

RM 0.2

0.00

0.00

0.00

0.00

0.06

RM 1.4

0.00

0.00

0.00

0.05

0.05

$\mathrm{RM} \quad 5.4$

0.00

0.07

0.00

0.00

0.00

Poorman $\mathrm{Cr}$

\section{RM 4.4}

0.00

1.02

0.00

0.12

0.00

0.14

0.00

RM 9.9

0.00

0.01

0.06

0.00

0.00

Landers Fork

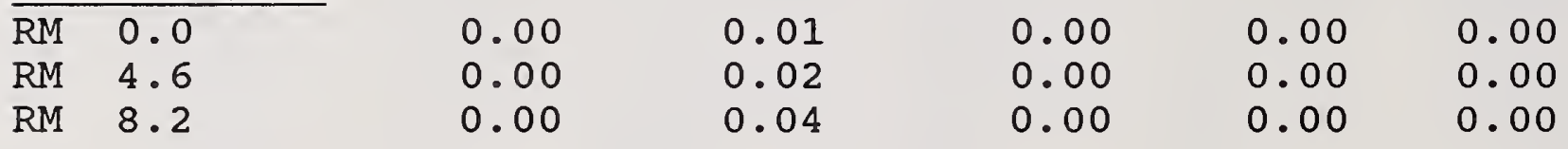

\section{Copper $\mathrm{Cr}$}

$\begin{array}{lrlllll}\mathrm{RM} & 1.3 & 0.00 & 0.05 & 0.00 & 0.00 & 0.00 \\ \mathrm{RM} & 6.2 & 0.00 & 0.12 & 0.21 & 0.00 & 0.00 \\ \mathrm{RM} & 8.9 & 0.00 & 0.00 & 0.00 & 0.00 & 0.00 \\ \mathrm{RM} & 10.8 & 0.00 & 0.00 & 0.00 & 0.00 & 0.00\end{array}$




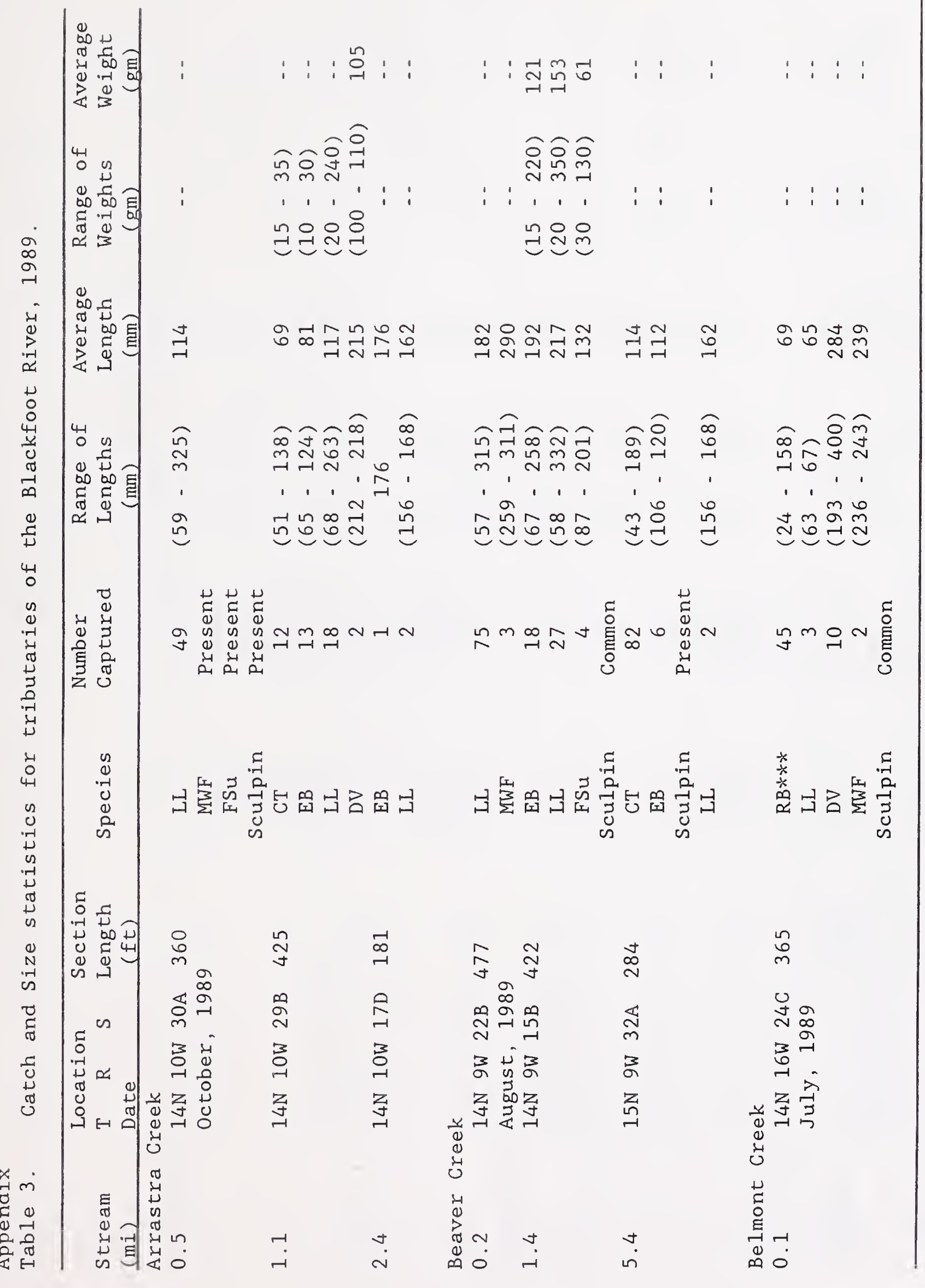




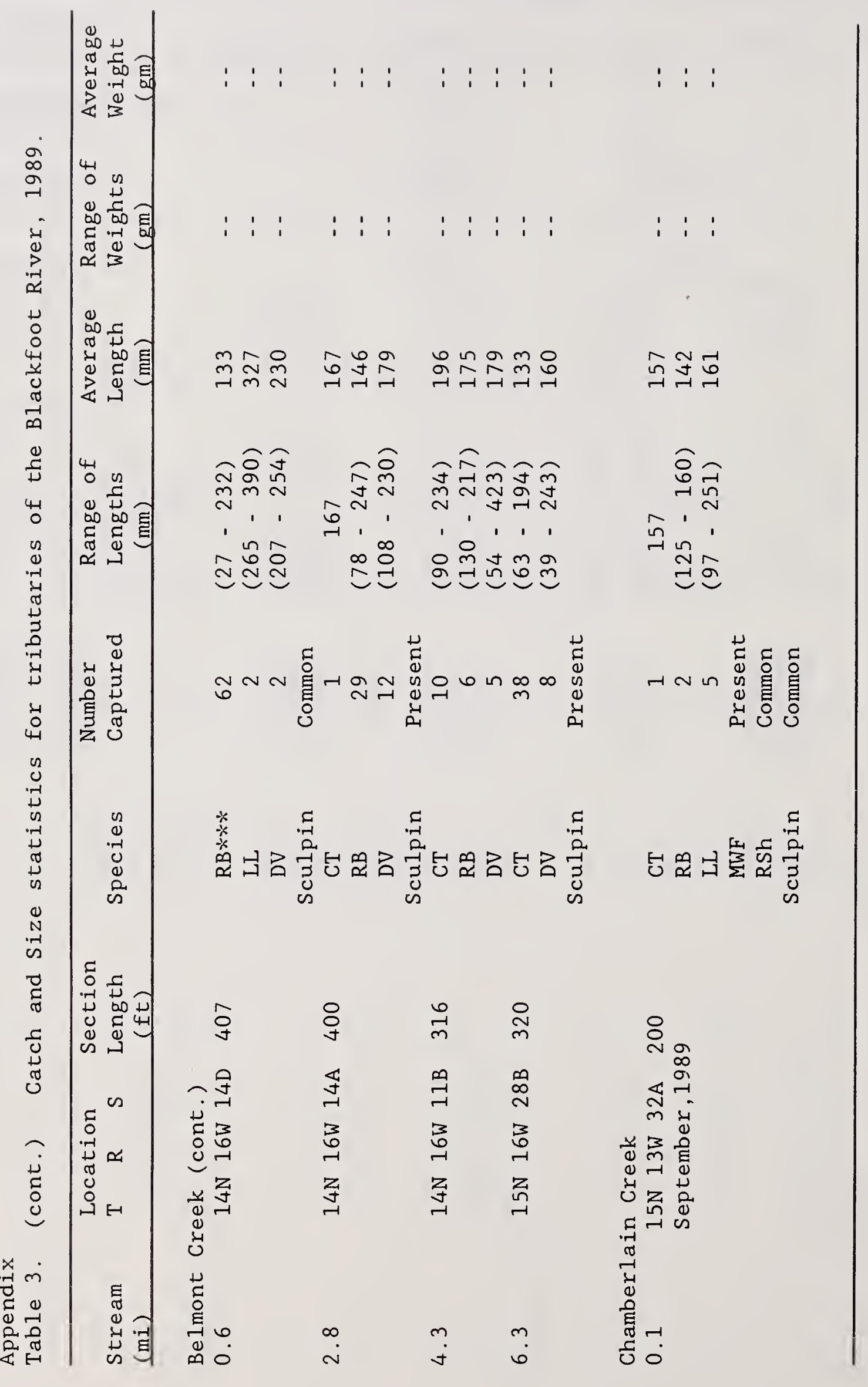




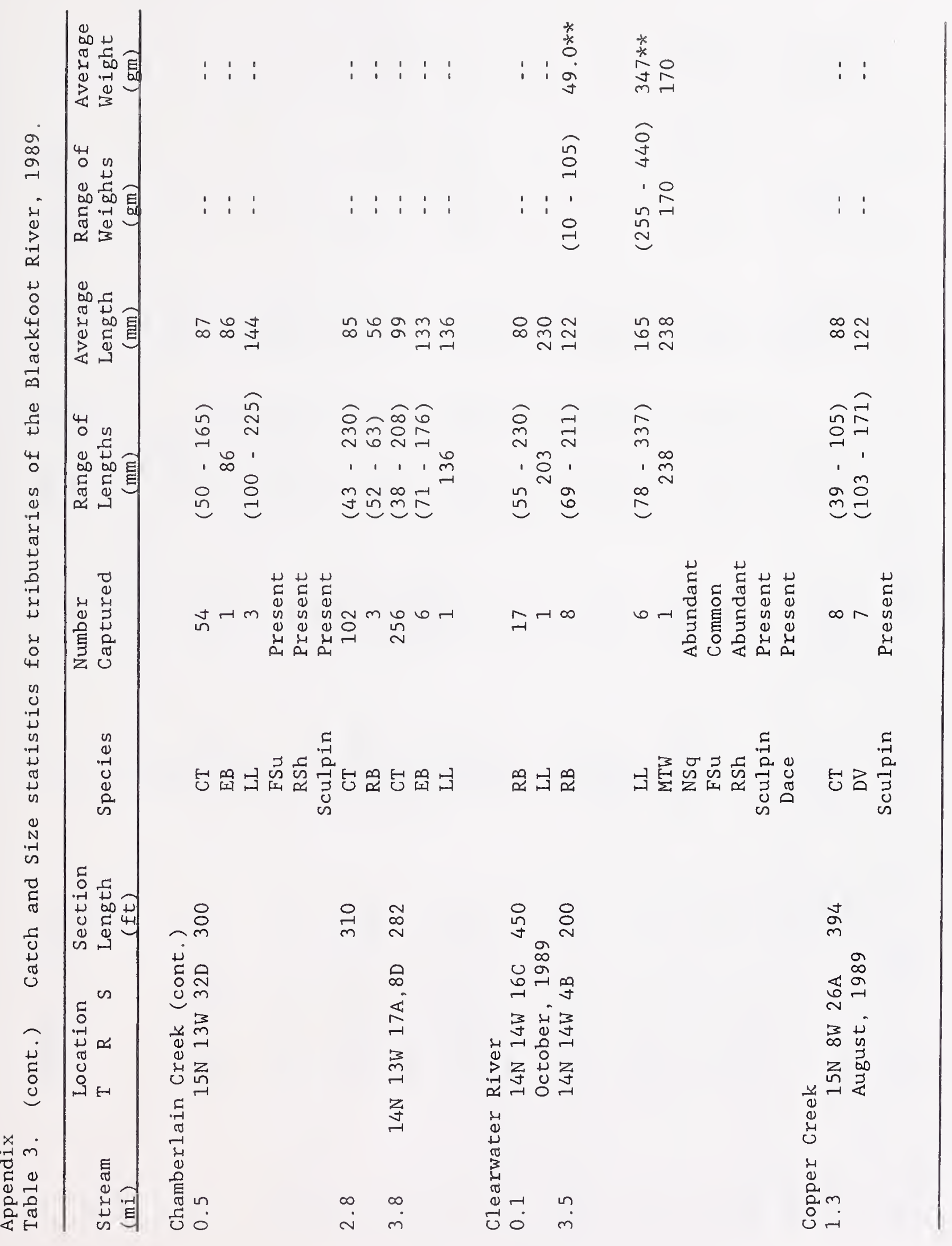




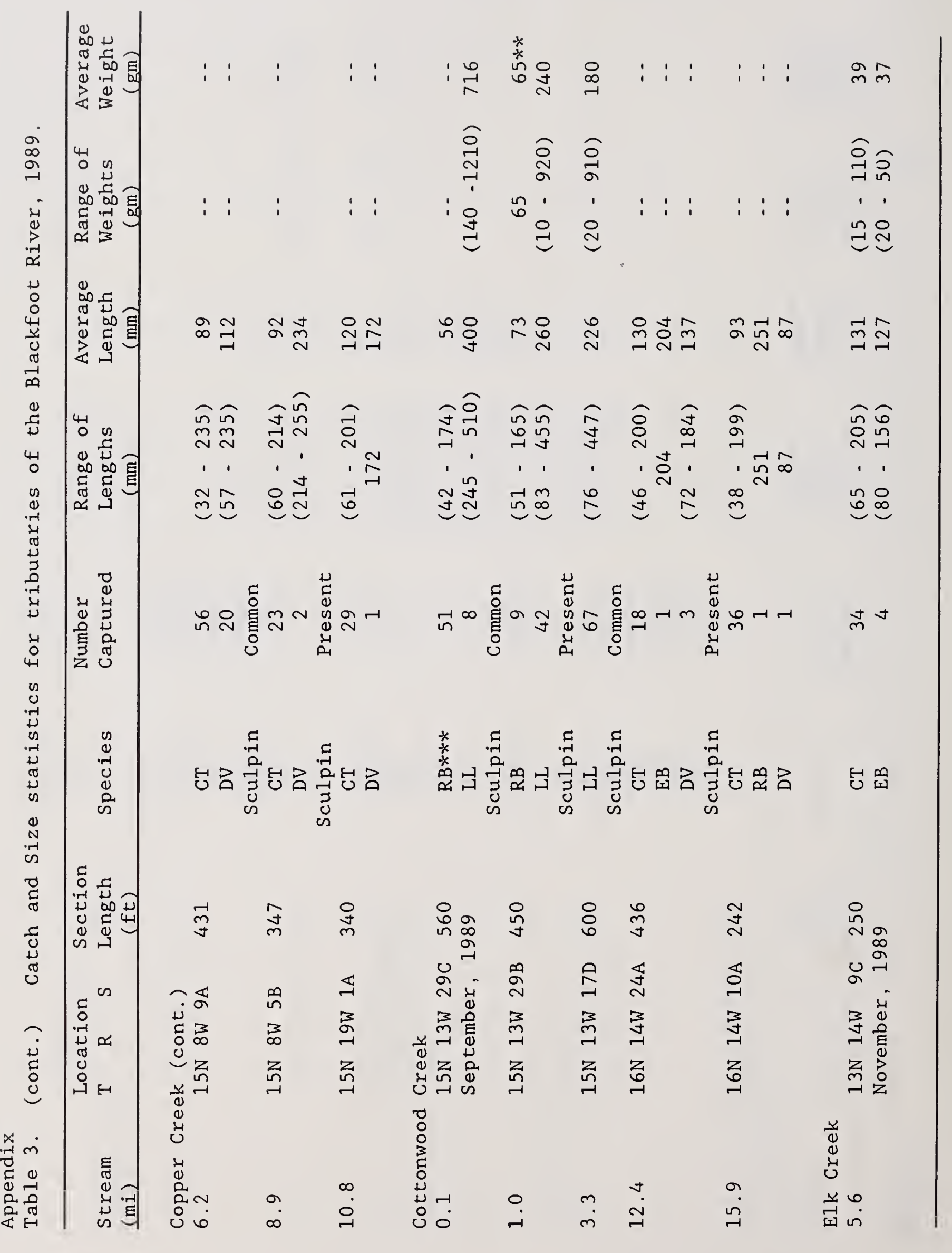




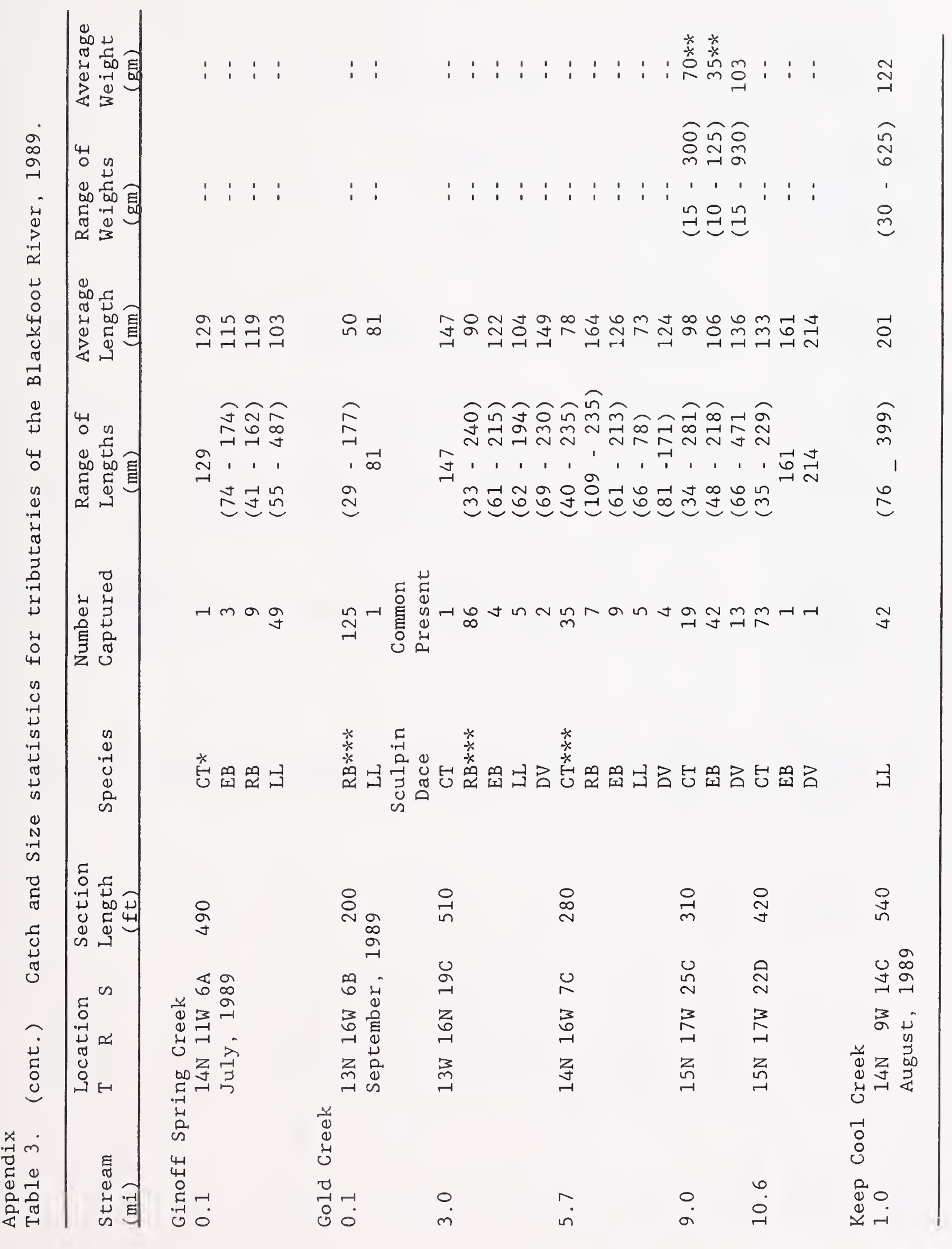




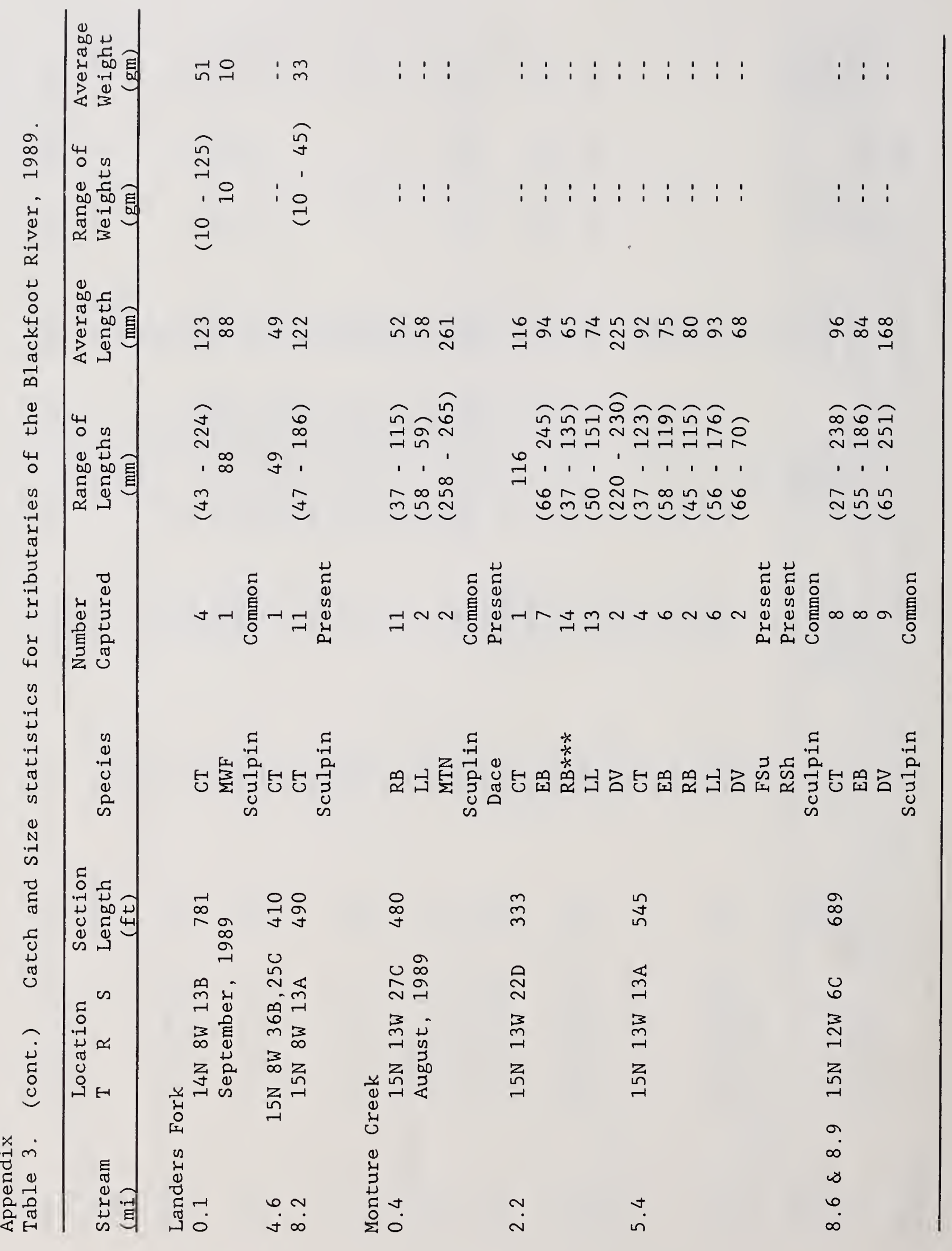




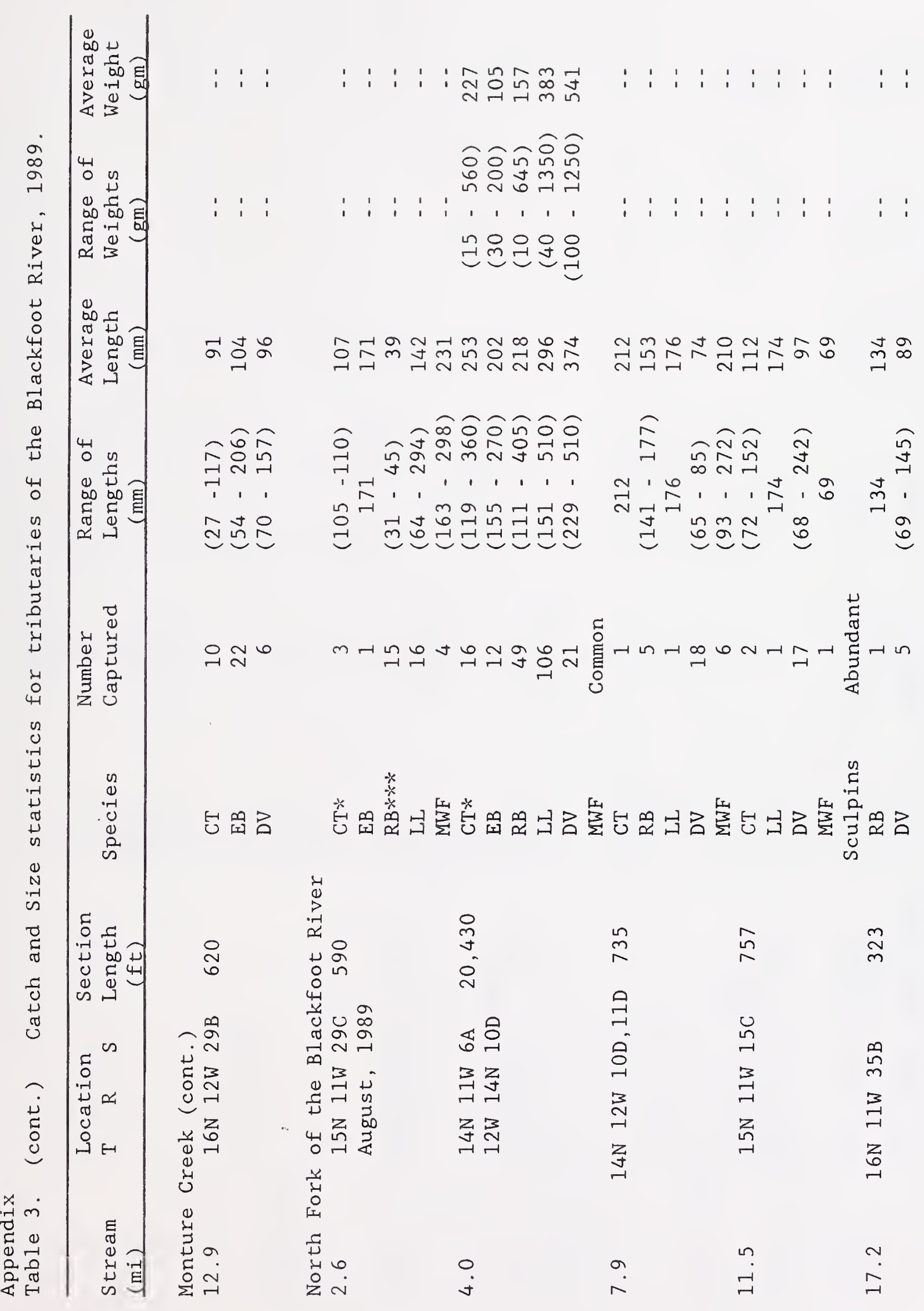




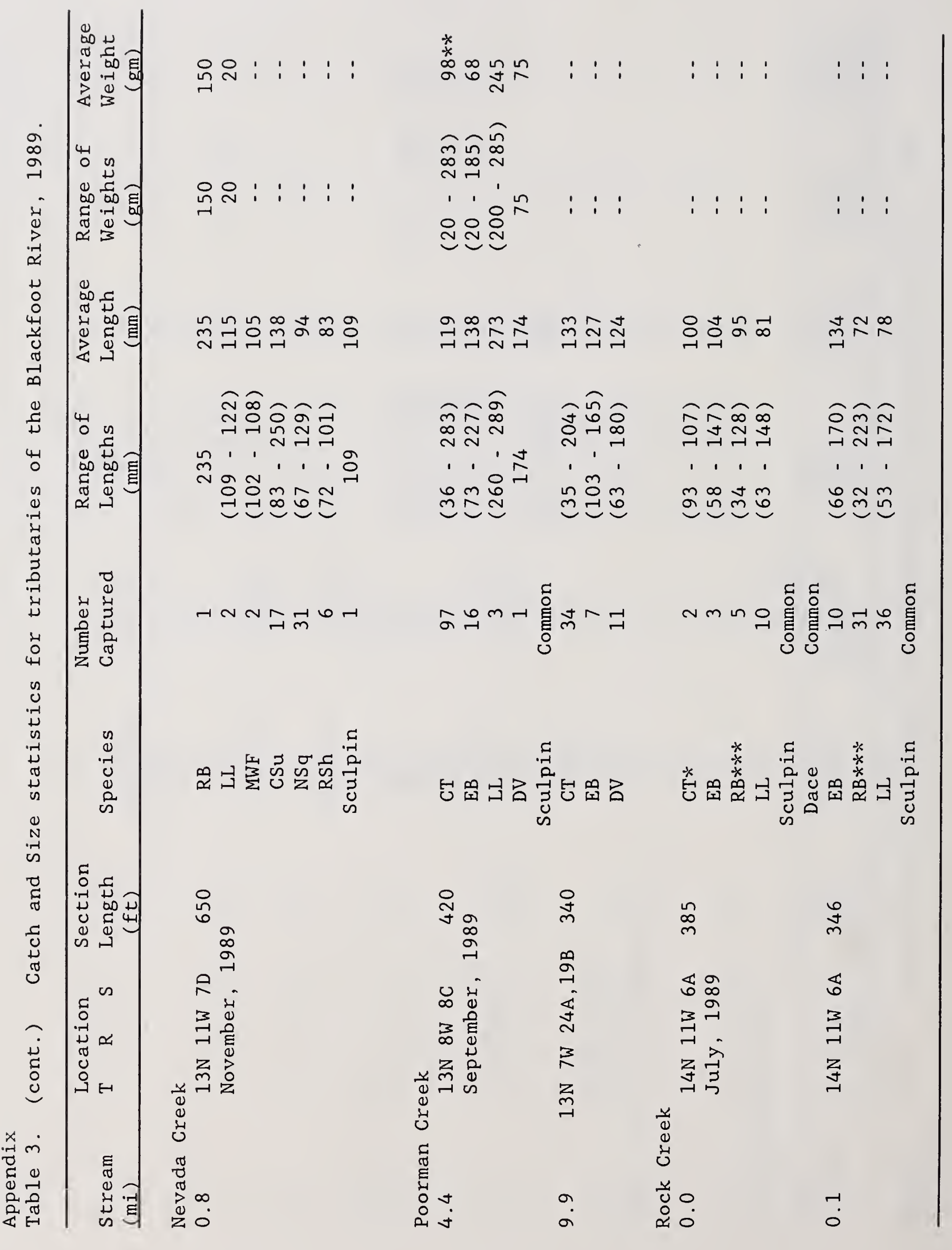




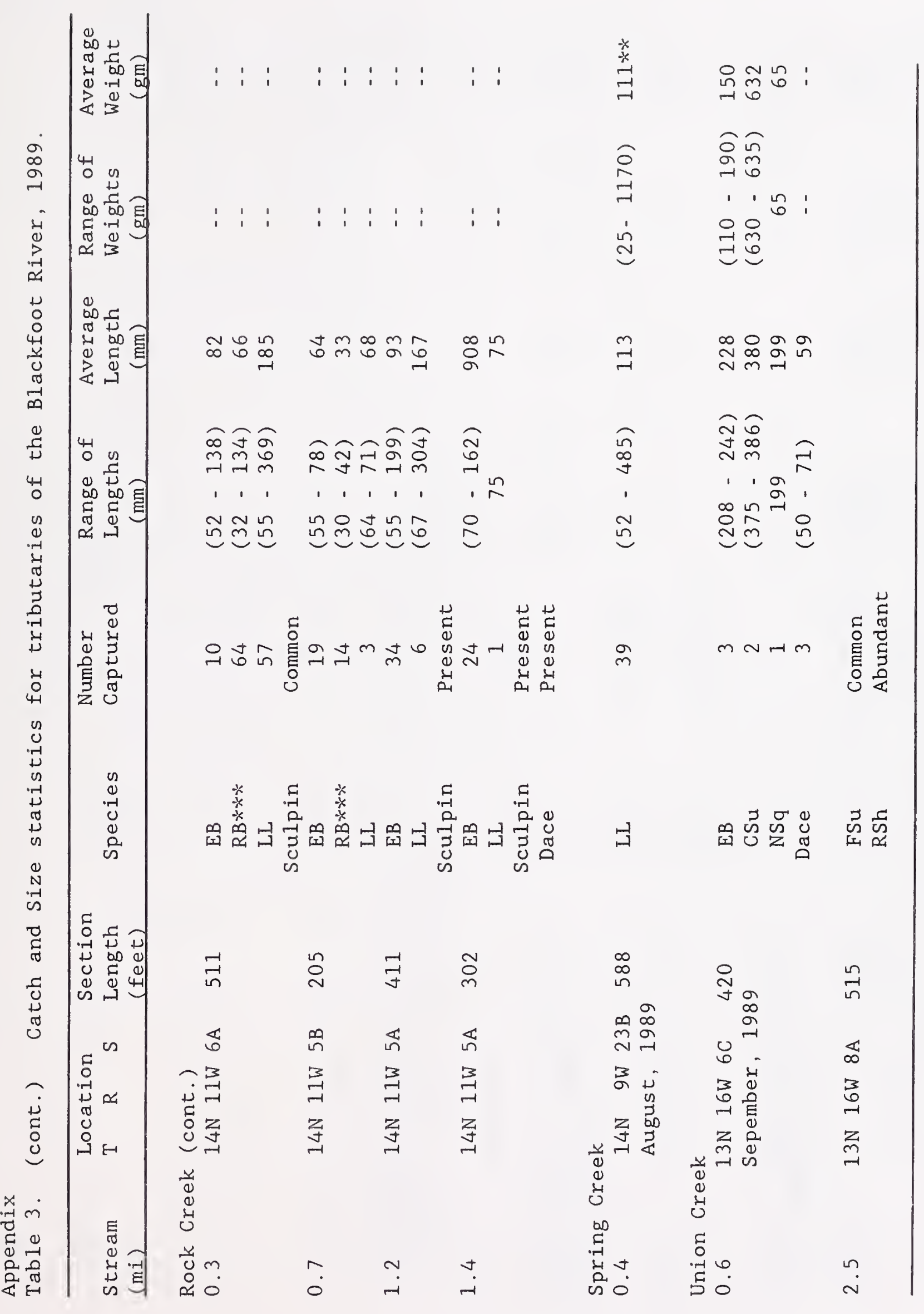




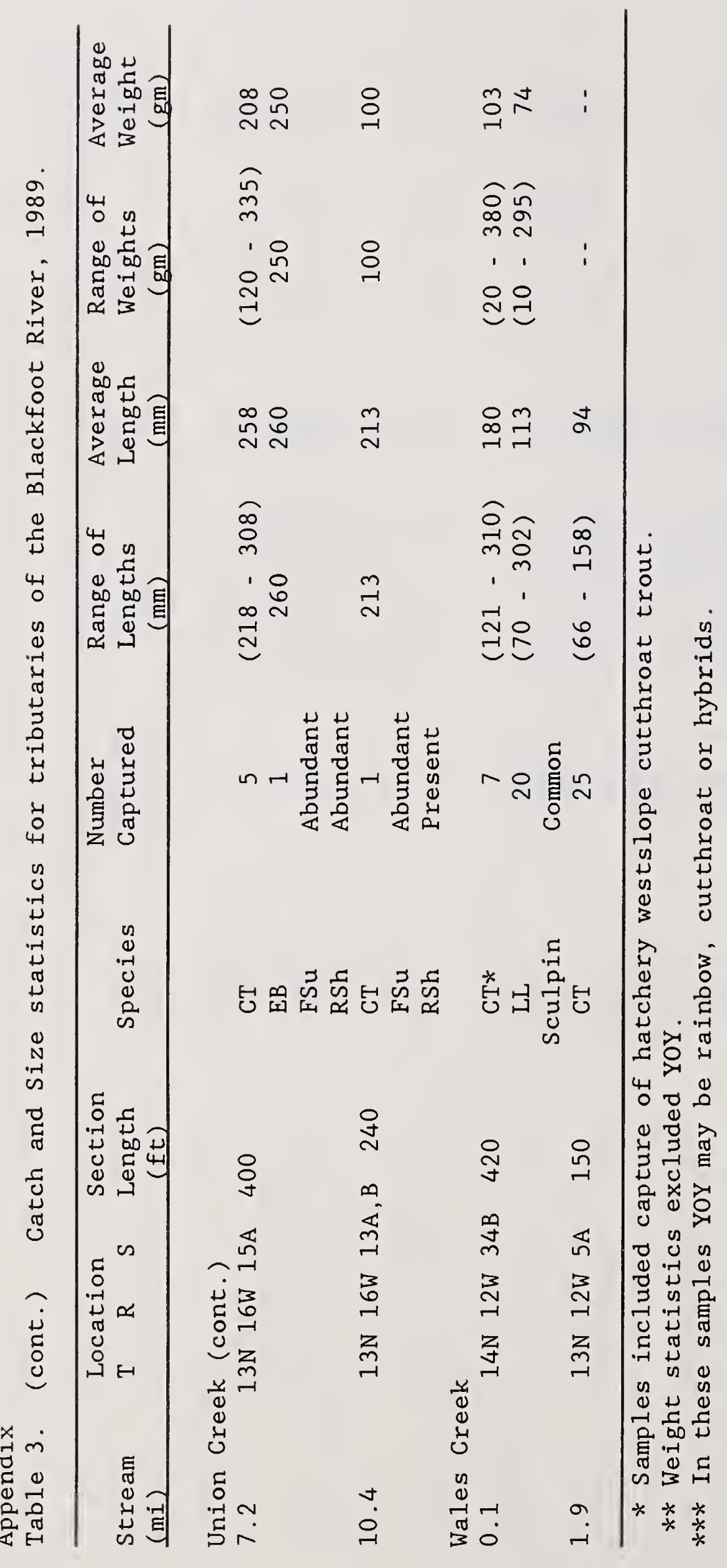




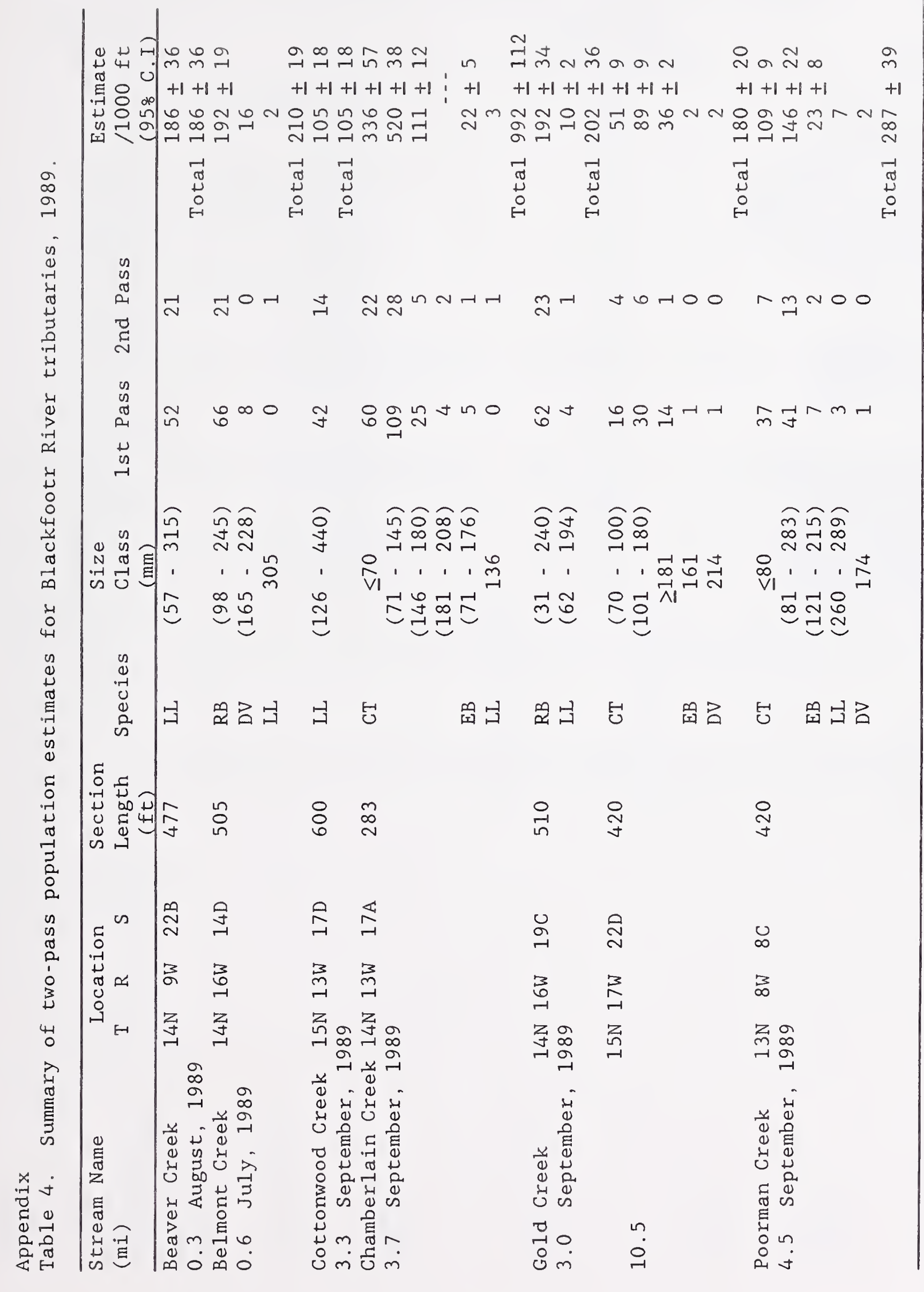


Table 5. Summary of stream discharge measurements taken in 1989.

\begin{tabular}{lrrr}
\hline Stream & $\begin{array}{c}\text { Location } \\
\text { (stream mile) }\end{array}$ & Date & $\begin{array}{c}\text { Discharge } \\
\text { (cfs) }\end{array}$ \\
\hline Union Creek & 0.1 & $10 / 17 / 89$ & 6.4 \\
Gold Creek & 0.1 & $9 / 6 / 89$ & 24.3 \\
Belmont Creek & 0.1 & $8 / 1 / 89$ & 13.0 \\
Clearwater River & 0.1 & $10 / 3 / 89$ & 98.3 \\
Cottonwood Creek & 0.2 & $9 / 27 / 89$ & 35.1 \\
Chamberlain Creek & 2.7 & $10 / 3 / 89$ & 2.1 \\
Monture Creek & 0.4 & $8 / 9 / 89$ & 44.2 \\
North Fork & 15.5 & $8 / 16 / 89$ & 174.4 \\
& 2.3 & $8 / 16 / 89$ & 299.5 \\
Rock Creek & 0.2 & $7 / 24 / 89$ & 53.0 \\
Ginoff Creek & 0.1 & $7 / 24 / 89$ & 25.0 \\
Wales Creek & 0.1 & $9 / 19 / 89$ & 1.4 \\
Nevada Creek & 0.3 & $11 / 1 / 89$ & 43.8 \\
& 6.0 & $11 / 2 / 89$ & 16.3 \\
Blackfoot River & 67.8 & $11 / 1 / 89$ & 173.8 \\
Arrastra Creek & 0.5 & $8 / 23 / 89$ & 16.9 \\
Beaver Creek & 0.2 & $8 / 24 / 89$ & 10.7 \\
Grantier Creek & 1.1 & $10 / 11 / 89$ & 4.1 \\
Poorman Creek & 2.2 & $11 / 2 / 89$ & 2.0 \\
Lander's Fork & 1.1 & $9 / 13 / 89$ & 94.9 \\
Copper Creek & 1.3 & $8 / 30 / 89$ & 35.5 \\
& & & \\
\hline
\end{tabular}




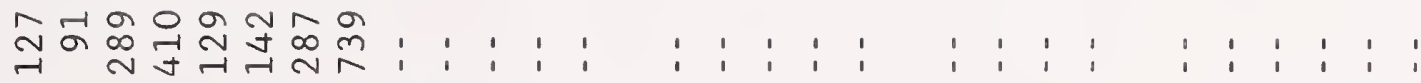

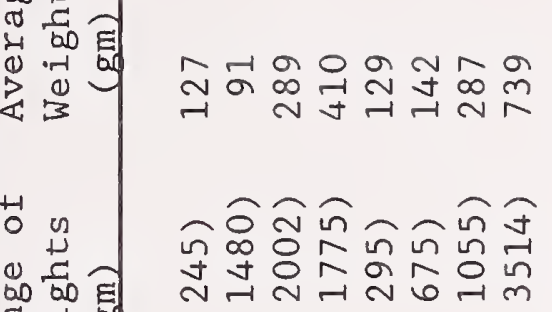

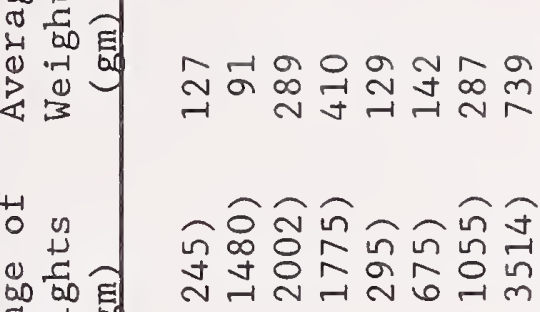

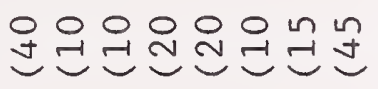

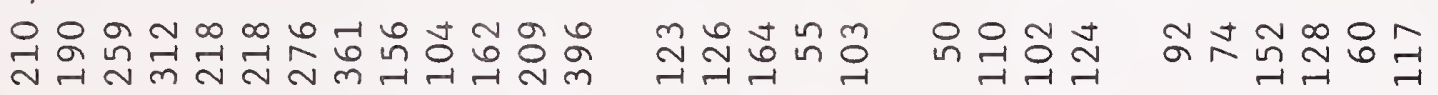

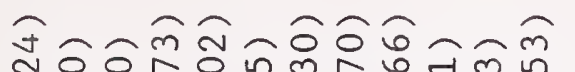

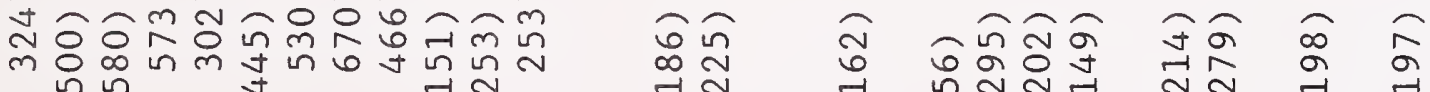

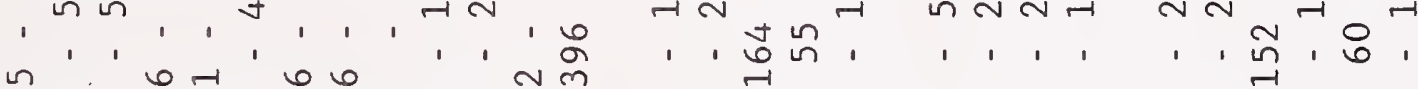

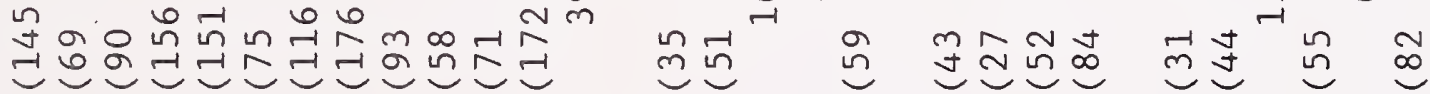

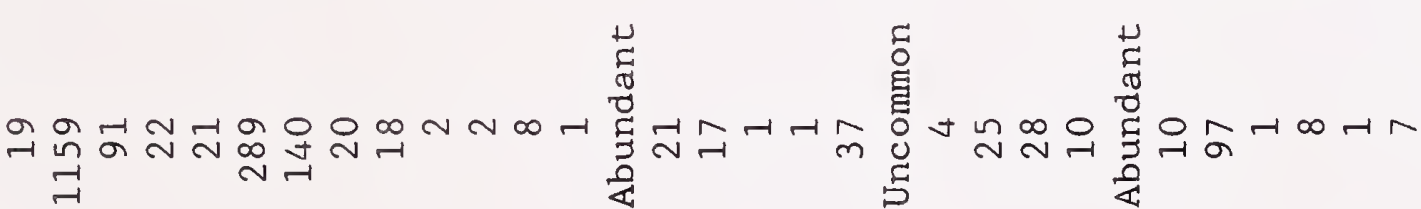

(1)




